Portland State University

PDXScholar

$1-1-2012$

\title{
Long-term Responses of Phalaris arundinacea and Columbia River Bottomland Vegetation to Managed Flooding
}

Tina Schantz Farrelly

Portland State University

Follow this and additional works at: https://pdxscholar.library.pdx.edu/open_access_etds

Part of the Environmental Sciences Commons

Let us know how access to this document benefits you.

Recommended Citation

Farrelly, Tina Schantz, "Long-term Responses of Phalaris arundinacea and Columbia River Bottomland Vegetation to Managed Flooding" (2012). Dissertations and Theses. Paper 787.

https://doi.org/10.15760/etd.787

This Thesis is brought to you for free and open access. It has been accepted for inclusion in Dissertations and Theses by an authorized administrator of PDXScholar. Please contact us if we can make this document more accessible: pdxscholar@pdx.edu. 
Long-term Responses of Phalaris arundinacea and Columbia River

Bottomland Vegetation to Managed Flooding

by

Tina Schantz Farrelly

A thesis submitted in partial fulfillment of the requirements for the degree of

Master of Science

in

Environmental Science and Management

Thesis Committee:

J. Alan Yeakley, Chair

Elaine M. Stewart

Joseph A. Maser

Portland State University

(C)2012 


\begin{abstract}
I sought to determine the effect of managed flooding on Phalaris arundinacea L. and other plant species distributions in a large wetland complex, Smith and Bybee Wetlands (SBW), in northwestern Oregon. Altered hydrology has reduced historically high spring flow and prematurely initiated the historic summer drying period at SBW. This alteration has increased the coverage of invasive plants (e.g., P. arundinacea) causing a decrease in native plant cover and thus degrading ecological functions. SBW managers installed a water control structure (WCS) between SBW and the Columbia Slough/River system to impound winter rainfall and thus approximate the ecological benefits that natural flooding provided as well as reduce the abundance of $P$. arundinacea. Prior researchers conducted intensive vegetation and hydrological monitoring in 2003 (during the season immediately before WCS installation) and 2004. I conducted similar analysis in the fifth and sixth years, 2008 and 2009, following establishment of the WCS. Both study years, I determined percent cover of all vegetation on transects established in 2003 . The results, including 2004, as well as 2008 and 2009 showed a reduced cover of P. arundinacea in areas experiencing at least 0.6 meters of inundation and an increased cover of native plant communities when compared to the 2003 baseline data. Native Carex aperta Boott. cover increased 7 -fold from $0.3 \%$ to $2.3 \%$; Polygonum species cover increased from 20.0\% to 52.6\%; and Salix lucida Muhl. ssp. lasiandra (Benth.) E. Murray cover
\end{abstract}


increased from $10.9 \%$ to $15.5 \%$ cover. P. arundinacea declined by over one-third from $44.4 \%$ to $28.1 \%$ cover following water management. Since hydrology management began, the native Polygonum species community replaced P. arundinacea as the dominant species in the emergent zone. The results of this study refined the suggested depth of inundation needed to reduce $P$. arundinacea cover in such lake-wetland complexes as SBW from 0.85 meters (based on 2004 study results) to 0.6 meters. Shannon Diversity decreased following water management. The findings of this study demonstrated that water management can enhance native bottomland communities, especially those comprised of obligate wetland species, and reduce $P$. arundinacea cover in areas experiencing at least 0.6 meters of inundation. 


\section{Acknowledgements}

Thanks to J. Alan Yeakley and Elaine M. Stewart for the opportunity to work on this amazing project. They provided immeasurable guidance, insight, and support throughout the process. Thanks to Noah Jenkins for his original work in establishing the study design and methods and for his availability during my field work and analysis endeavors. Thanks to Joseph Maser for agreeing to be on my committee, even with very little communication on my part.

I would also like to thank Metro Regional Government, Oregon Watershed Enhancement Board, and Portland State University for partial funding of my work. In addition, the GIS department at Metro was pivotal in compiling the vast project data into a geodatabase.

Thanks to Kellie Ernst, Peter Farrelly, Matthew Humphrey, Sybil Kelley, and Joey Lubitz for field assistance. Kellie Ernst and Matthew Humphrey put in some major labor lugging around the elevation survey equipment.

Thanks to Peter Farrelly. Not only did he help create two new lives during this process, he also put in some serious daddy duty these past few months while I finalized my thesis and defense. 


\section{Table of Contents}

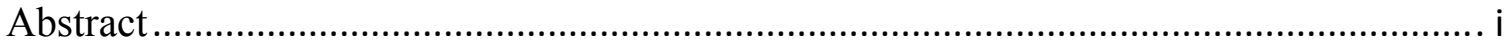

Acknowledgements .................................................................................................ii

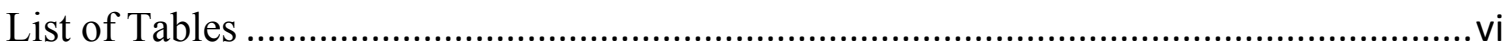

List of Figures .................................................................................................... vii

List of Abbreviations/Symbols .....................................................................................viii

Chapter 1: Introduction ...................................................................................... 1

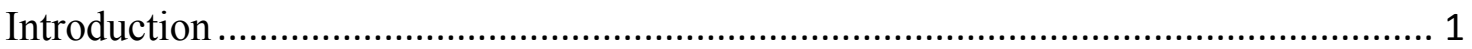

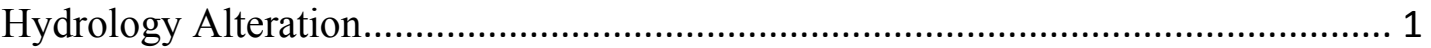

Invasive Species and Native Species Loss ........................................................ 3

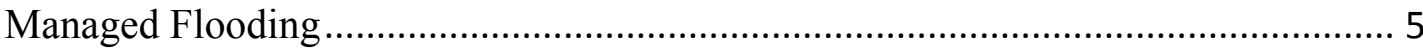

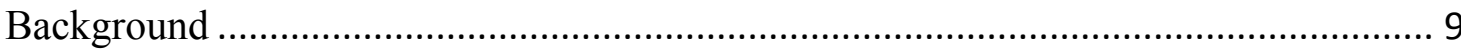

Study Area ................................................................................................... 9

Phalaris arundinacea - Phenology and General Characteristics............................. 14

Phalaris arundinacea - Response to Flooding and other Control Measures............. 16

Other Important Flora - Phenology and Response to Flooding ................................ 23

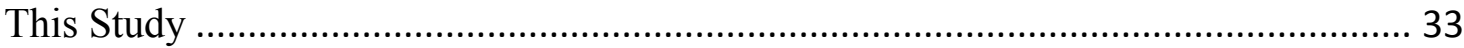

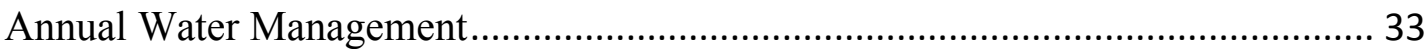

Research Questions and Hypotheses ....................................................................... 36

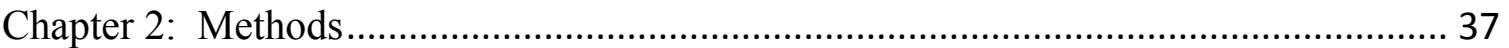

Study Design and General Methods........................................................................... 37

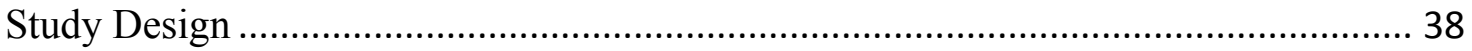

Transect Point Selection and Location .................................................................. 38

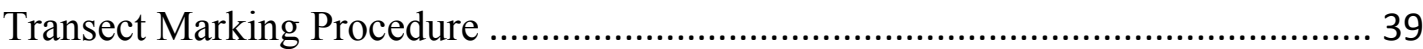

Transecting Procedure ........................................................................................ 41

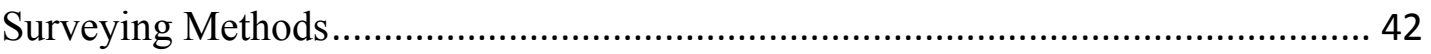

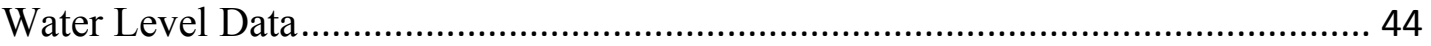

Statistical Methods: Abundance Response of Taxa ..................................................... 45

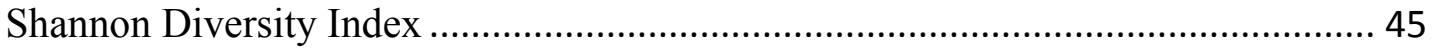




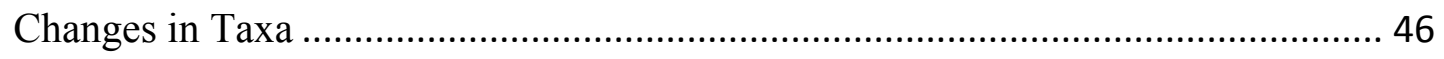

Interaction of Phalaris arundinacea with Other Taxa ………................................. 47

Determination of Depth and Duration of Flooding .................................................. 48

Impact of Flooding and Salix on Phalaris arundinacea Response ............................ 50

Interaction of Phalaris arundinacea and Polygonum with Inundation ...................... 51

Cover Changes by Elevation/Maximum Inundation/Duration of Inundation ............ 53

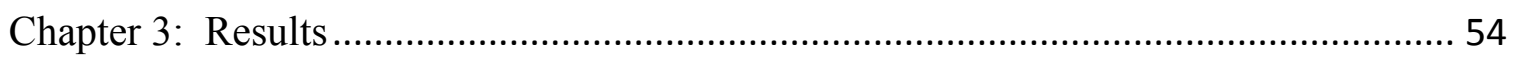

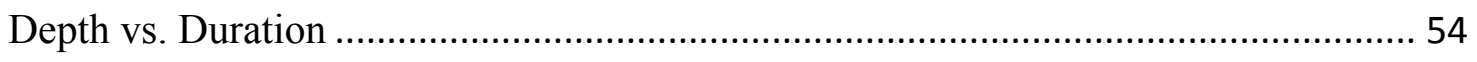

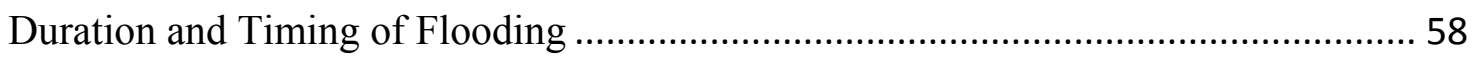

Phalaris arundinacea Response to Water Management................................................ 60

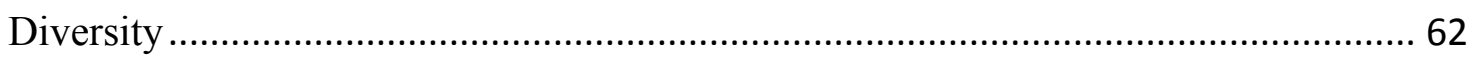

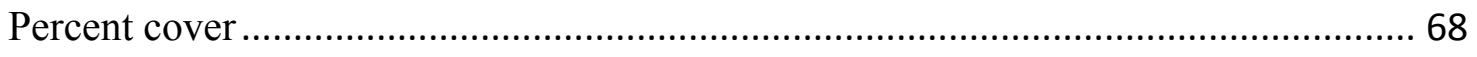

Interaction of Phalaris arundinacea with Other Taxa ................................................. 91

Phalaris arundinacea Response to Shading and Hydrology ........................................ 96

Phalaris arundinacea - Polygonum species Interaction and Hydrology ...................... 97

Cover Changes by Maximum Inundation/Duration of Inundation ............................... 98

Chapter 4: Discussion and Conclusions...................................................................... 109

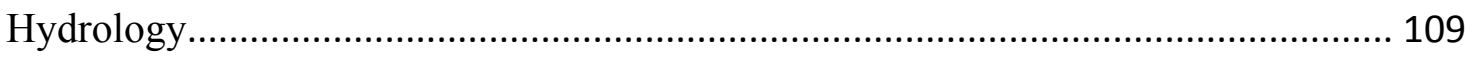

Phalaris arundinacea Response to Water Management........................................... 110

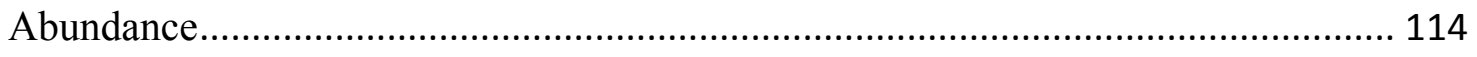

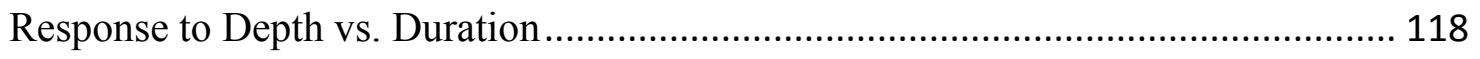

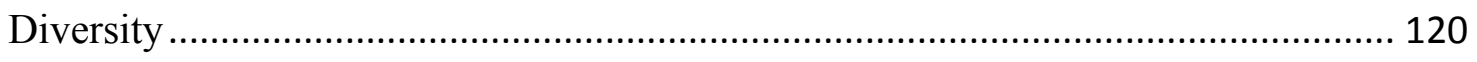

Conclusions/Management Implications ................................................................... 123

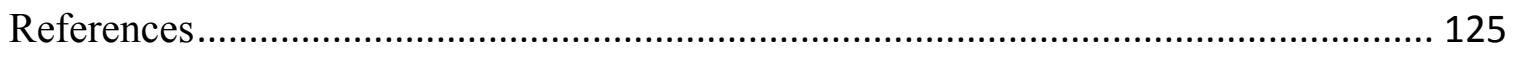

Appendix A: List of Plant Species Found on Transects ............................................... 136

Appendix B: Differences in Results between Lakes.................................................... 137

Appendix C: Elevation Survey Details .................................................................... 140 


\section{List of Tables}

Table 1: Phenology and Flood Tolerance of Key Species........................................... 24

Table 2: Water Management Summary..................................................................... 35

Table 3: McNemar Contingency Table Structure for a Single Species.......................... 47

Table 4: McNemar Contingency Table Structure for Two Species................................ 48

Table 5: Phalaris - Polygonum Response Categories.............................................. 52

Table 6: Transect Hydrology for 2007/2008 and 2008/2009 Water Years. ................... 59

Table 7: Shannon Diversity Index values.............................................................. 62

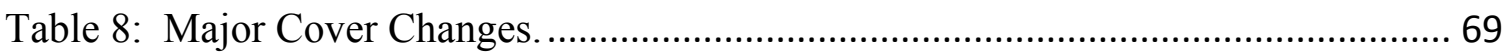

Table 9: Invasive Species Cover Changes............................................................... 75

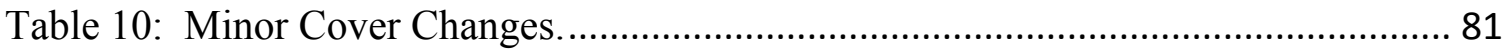

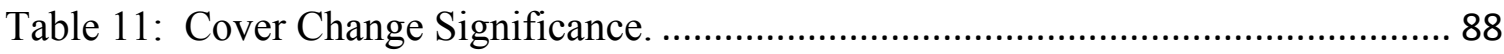

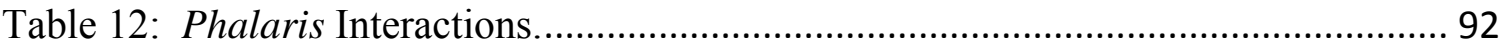

Table 13: Relationship Between Shading, Maximum Inundation, and Phalaris Cover.. 97

Table 14: Maximum Inundation and Phalaris/Polygonum Interaction. ........................ 98

Table 15: Elevation, Depth, and Duration in 2009.................................................. 99

Table 16: Elevation-Based Cover Change Significance........................................... 104 


\section{List of Figures}

Figure 1: Historic Project Vicinity..................................................................... 8

Figure 2: Study Area Aerial Photograph. ................................................................ 10

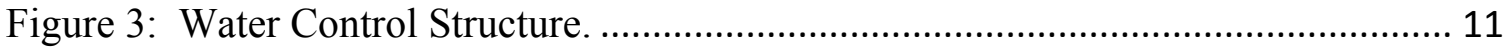

Figure 4: Vegetative Growth and Flowering Period for Important Taxa. ....................... 32

Figure 5: Average Pre- and Post-Water Management Hydrographs. ............................. 54

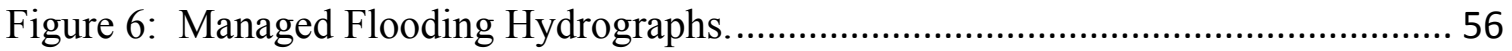

Figure 7: Important Hydrographs for This Study. ................................................... 57

Figure 8 a.-b.: Phalaris Cover and Change by Maximum Inundation. ........................... 61

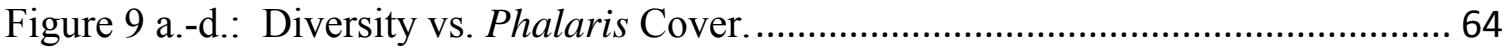

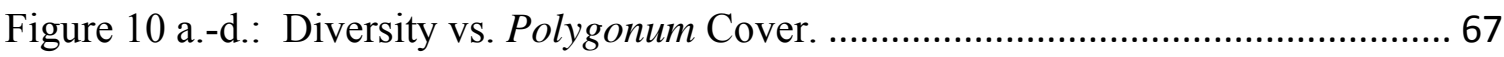

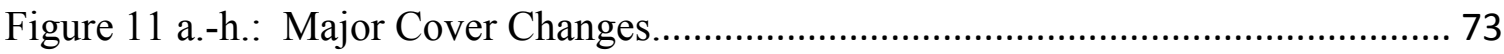

Figure 12 a.-h.: Invasive Species Cover Changes...................................................... 79

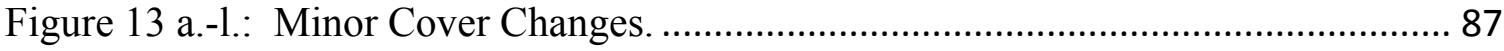

Figure 14: Phalaris and Salix Cover Relationship. ................................................ 91

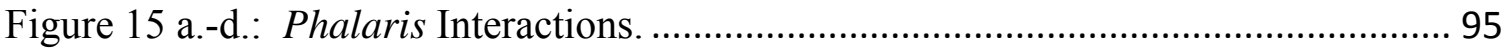

Figure 16 a.-g.: Elevation-Based Vegetation Profiles in 2003 and 2009..................... 103

Figure 17: Stacked Graphs of Cover Changes Based on Maximum Inundation........... 108 


\section{List of Abbreviations/Symbols}

Bidens

Carex

Ludwigia

Phalaris

Polygonum

Salix

SBW

Veronica

WCS
Bidens species

Carex species

Ludwigia palustris

Phalaris arundinacea

Polygonum species

Salix species

Smith and Bybee Wetlands

Veronica species

Water Control Structure 


\section{Chapter 1: Introduction}

\section{Introduction}

Evaluating the success of the Smith and Bybee Wetland Natural Area (SBW) water management regime, and wetland restorations in general, is an important step in natural resources management. Wetland restoration projects are generally only monitored and/or studied for 2 to 5 years after implementation for a variety of reasons (Nedland et al. 2007). However, the evaluation of restoration success is likely more significant after 15 to 20 years (Mitsch and Wilson 1996) or longer (Zedler and Callaway 1999). In this study, I evaluated longer-term progress of water management at SBW through the collection and analysis of vegetation data during the 5 th and 6 th years after implementation and through the establishment of a database in which to compile, analyze, and continually incorporate new data.

\section{Hydrology Alteration}

Many floodplain ecosystems in the United States are highly altered from their historic conditions. In urban settings, floodplains are cut off from the larger river system physically, by surrounding industrial developments, and hydrologically, by alterations

due to dams, by fill material, and by other flood control measures (Bayley 1995). The loss of connectivity and the departure from historic hydrological regimes can result in a loss of biotic diversity (Michener and Haeuber 1998) and invasion by non-indigenous species (Warren et al. 2002). Species richness and diversity are reduced in floodplain areas that no longer experience seasonal variations in hydrology and remain dry or wet 
for longer periods than the area experienced historically (Barrett et al. 2010). Fluctuating water levels increase diversity because periods of low water allow buried or submerged seeds to germinate and periods of high water create gaps in vegetation upon which species can colonize. Stabilization of water regime eliminates this dynamic process, reducing the area of shoreline vegetation of floodplain systems (Keddy and Reznicek 1986).

Unaltered floodplains are among the most endangered ecosystems worldwide (Buijse et al. 2002). The land-to-water continuum of natural floodplains has been partitioned into a land component and an aquatic component, with little of the intermediate zone of wetlands, marshes, and floodplains remaining connected to the larger system (Bayley 1995). In part, this is the result of the view of floods as disturbances and/or natural disasters, not natural parts of a functioning ecosystem (Michener and Haeuber 1998). Bayley (1995) argues that it is actually the deviation from regular cycles of flooding, to which biotic communities have adapted, that is the disturbance.

Because many of our cities and their industrial, residential, commercial, and agricultural areas have been constructed in floodplains, we have tried to prevent flooding to avoid property damage and other disruptions (Michener and Haeuber 1998). Dikes and levees were erected to keep river systems within their banks, fill material was placed in floodplains to develop the land, dams were constructed for hydroelectric power generation and flow regulation, channels were dredged and straightened to facilitate river commerce, and lowland areas were drained for agricultural and industrial use. Any one 
of these modifications could alter the timing, amplitude, frequency, and duration of high water in floodplains (Moorhead et al. 2008).

Dahl (1990) estimates that over half of the wetland area in the lower 48 states and approximately 38 percent of Oregon's wetland area has been lost since 1780 . Wetland loss and degradation, floodplain encroachments, and "flood control" measures make the intensity of floods, when they do occur, much greater because of lost storage capacity. Further, there is a loss of wildlife habitat, natural water quality improvement capacity, and natural drought remediation associated with the loss of wetlands and floodplain systems (USEPA 2010). The restoration of historic hydrological conditions is hypothesized to reverse the effects resulting from hydrology alterations (Tanner et al. 2002, Warren et al. 2002).

\section{Invasive Species and Native Species Loss}

Invasive plant species are an enormous problem both environmentally and economically. In the United States, estimates of the financial cost of invasive species range from millions to billions of dollars each year (Pimentel et al. 2000). Invasive plants can damage the structure of native plant and animal communities and disrupt fire regimes, nutrient cycling, hydrology, and other important ecosystem functions (Blossey 1999, Levine et al. 2003). The invasion process occurs in (at least) three phases including the immigration of propagules, the establishment of the species within the new territory, and the spread of the species and its replacement of the native flora (Adams and Galatowitsch 2005). At each step in the process there are significant barriers that the invader must overcome such as large physical distances, local environment suitability, reproductive 
factors (due to a small initial population size), and interactions with other trophic levels (e.g., herbivores, parasites, and pollinators) (Theoharides and Dukes 2007). Three of the most prominent theories as to why invasive plants are able to overcome these barriers to invasion, and not only to become naturalized to a new region, but also to negatively affect it were described in a 1999 study by Galatowitsch et al. The first is the theory that the new environment is more favorable to the growth of the invasive plant than its native environment (Galatowitsch et al. 1999, Lockwood et al. 2007). The second theory is that in its new environment, the invaders' natural controls (e.g., pathogens and herbivores) are absent and the invader is released from this pressure and has an increased vigor and competitive ability (Blossy and Notzold 1995, Galatowitsch et al. 1999, Lockwood et al. 2007). The third theory is that invasive plants are the result of interspecific hybridizations that make new species that are more vigorous than either of the parent plants in a particular environment (Lewontin and Birch 1966, Galatowitsch et al. 1999, Lockwood et al 2007). Regardless how the species was able to establish and spread within a community, once it does get established, physical removal of the species becomes very difficult, and in some cases nearly impossible. Managers of natural areas must utilize integrated pest management approaches and address propagule pressure to deal with invaded areas (Lavergne and Molofsky 2006). It is important to focus on preventing new infestations from both an economic and biological standpoint (Leung et al. 2002, Lockwood et al. 2007).

Wetlands in particular are very sensitive to invasion due to their landscape position. They receive water, sediment, and other inputs that often contain invasive propagules (Zedler and Kercher 2004 and Lavergne and Molofsky 2006). Although 
wetlands only cover approximately 6 percent of the earth's surface, 24 percent of the world's most invasive plants are wetland species (Zedler and Kercher 2004). The landscape position of floodplain wetlands also allows for successful importation of native propagules and the restoration of native communities through the connection to the river system and adjacent wetland systems (Fink and Mitsch 2004). Changes in the hydrology

of a wetland system, even minor changes, can favor establishment by invasive propagules in these dynamic floodplain wetland systems (Magee and Kentula 2005).

\section{Managed Flooding}

The important ecosystem services provided by floodplains and wetlands are being increasingly recognized. That, coupled with wetland regulations in place since the 1970s, has led to an increased focus on wetland restoration. Wetland restoration, intended to recreate the structure and function of the historic ecosystems (Hunter et al. 2008), restores tidal influences, provides salmonid habitat, increases productivity, and controls invasive species (Tanner et al. 2002). Floodplain wetlands that are connected to river systems are ideal for restoration; they have a dependable source of hydrology and propagules, they serve as valuable habitat for fish and aquatic life, they improve water quality in the river system, and they provide flood storage during flood events. Further, because many man-made and natural levees are present along the river-floodplain continuum, opportunities for restoration are abundant and relatively simple to implement (Fink and Mitsch 2004).

Wetlands are generally very dynamic systems characterized by seasonal and/or intra-annual variation in hydrology as well as less frequent, large-scale hydrological 
events (major floods) that drive ecological succession (Timoney 2002). Flood frequency, depth, and duration are the most important factors contributing to vegetative community structure, composition, and dynamics (Casanova and Brock 2000, Keddy and Fraser 2000). Human-induced stability to wetland systems reduces productivity and species diversity (Timoney 2002). The restoration of hydrology is critical to the wetland restoration process as it is the primary factor affecting wetland vegetation and soil processes (Baldwin et al. 2001, Hunter et al. 2008). Hunter et al. (2008) assert that successful restoration must include restored hydrology. Barrett et al. (2010) hold that maintaining connectivity to river systems can help restore species diversity in areas where it had been reduced due to hydrology stabilization. Leck (2003) found that even without donor soils, areas that were reconnected to river systems were able to recover species diversity through colonization from regional and local seed sources. Hydrology restoration sets a system on a recovery trajectory (Warren et al. 2002) with the damaged ecosystems passing through reorganization phases at variable rates (Michener and Haeuber 1998). Warren et al. (2002) found that rapid recovery was characterized by lower elevations, greater hydroperiods, and higher water tables.

To determine the success of restored wetland hydrology, researchers often document changes in the wetland hydroperiod before and after restoration to see if the post-restoration hydrologic patterns approach those that existed before site degradation. Longer pre- and post-restoration assessment periods capture climatic averages of rainfall and provide a more accurate description of pre-restoration conditions. Moorhead (2008) found that seven to eight years was generally sufficient time to differentiate between 
climatic variability (such as variability in rainfall, temperature, and snowmelt) effects and the effects of the management activity.

Like many other major river floodplains, the lowland area southeast of the confluence of the Columbia and Willamette Rivers has been highly altered from its natural state. Hydrological alterations associated with diking, draining, dredging, flow regulation, and the placement of fill material in the North Portland area have resulted in the loss of a majority of the historic wetlands, backwaters, and sloughs that once covered the area (Figure 1). The remaining wetlands are degraded hydrologically, with repercussions to all the abiotic and biotic components of the systems. In 2003, Metro Regional Government initiated a hydrological restoration project at SBW to mimic the historic water regime and consequently control invasive plant species, restore native plant communities, provide salmonid and other wildlife habitat, and enhance nutrient cycling (Jenkins et al. 2008). 


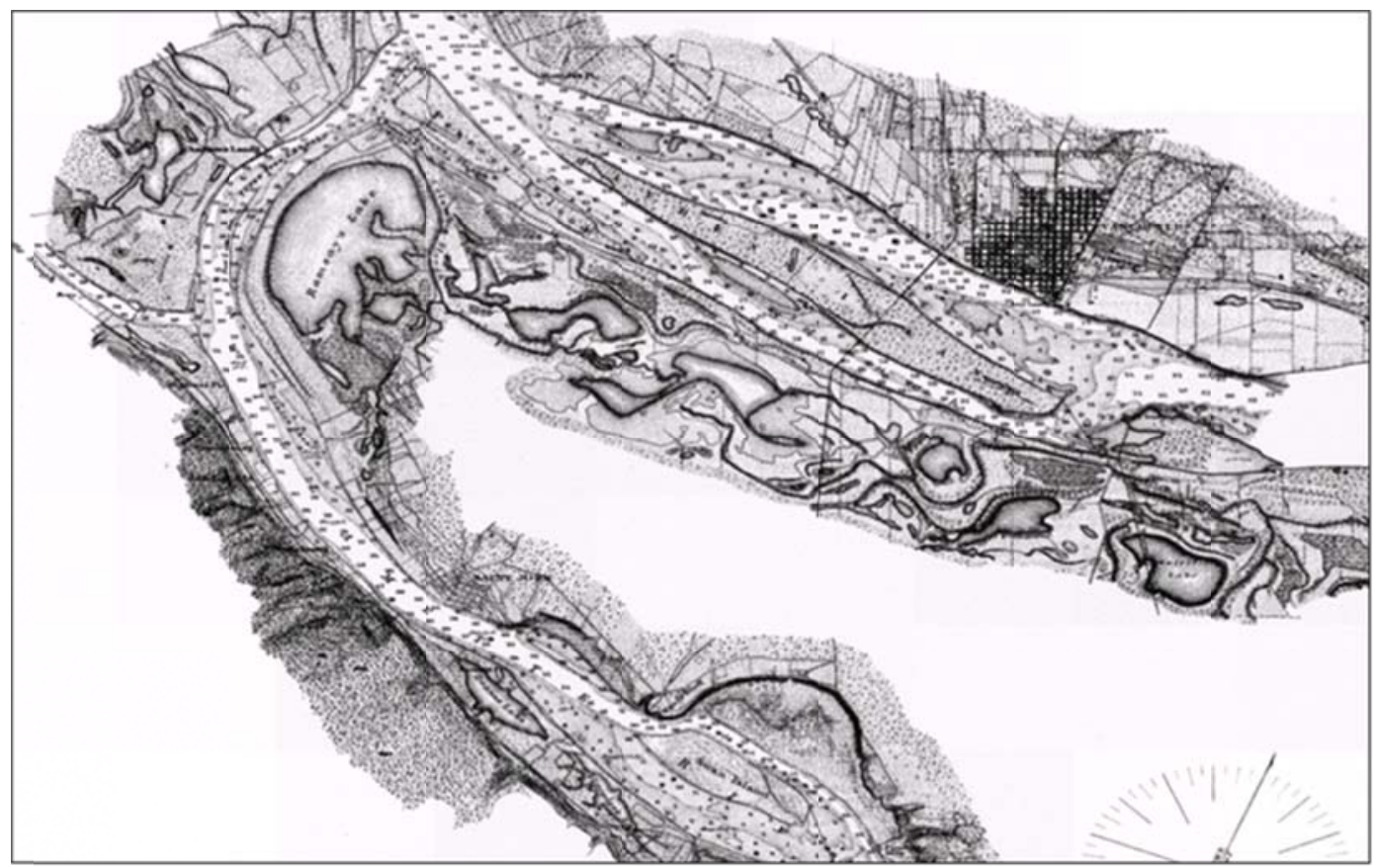

Figure 1: Historic Project Vicinity.

This figure depicts the 1888 Nautical Map (Office of Coast Survey 2010) of the area southeast of the confluence of the Columbia and Willamette Rivers. The project area is east of "Ramsays Lake." 


\section{Background}

\section{Study Area}

The study site (Figure 2) consists of an approximately 800 ha natural area, southeast of the confluence of the Columbia and Willamette Rivers. It is composed primarily of seasonal, semi-permanent, and permanently flooded wetlands and is a remnant of the once extensive system of lakes, wetlands, and sloughs found in the Columbia River bottomland area. SBW is divided into two large wetland components connected through a permanent channel. These wetland areas are referred to as Smith Lake and Bybee Lake, as they were historically known. Previous research conducted at the site by Jenkins (2005) established linear transects around the site in order to compare vegetation response to vegetation conditions prior to initiation of water management. 


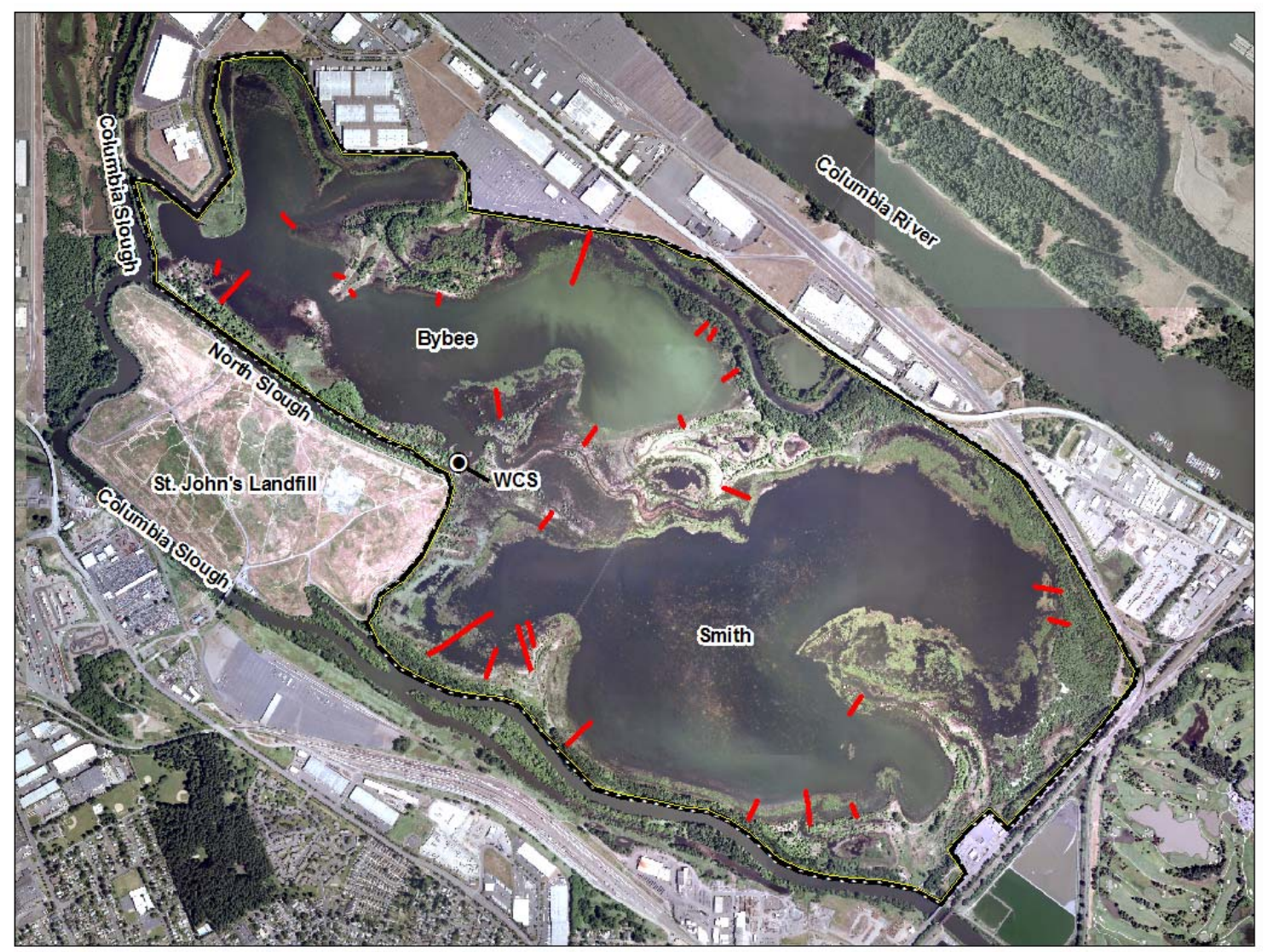

Figure 2: Study Area Aerial Photograph.

Shown is an aerial photograph of the study area, including the St. John's Landfill. The water control structure is located at the northeastern corner of the landfill, between the North Slough and Bybee Lake. Project data was collected along the 26 linear transects that are distributed randomly around the emergent zone.

The entire SBW is currently connected to the North Slough arm of the Columbia Slough via a water control structure on the southeast side of Bybee Wetland (Figure 3). The water control structure was installed during the fall of 2003. Construction began after September 22, 2003 and was completed by December 1, 2003. It consists of a fish ladder to allow salmonids continual access to and egress from SBW, three reverse tide gates, and an area of stop-logs to allow water to be held in or released from the wetland. 


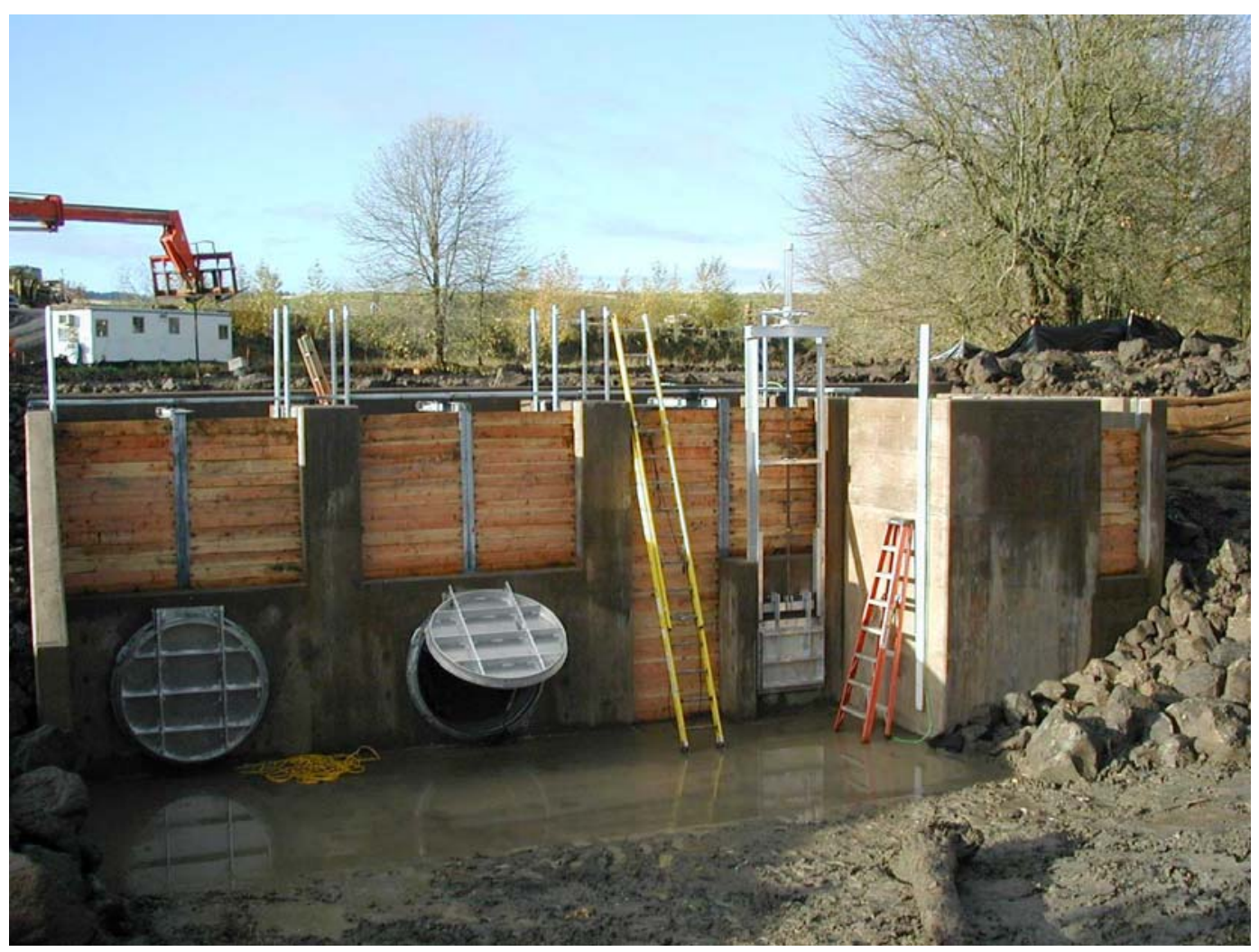

Figure 3: Water Control Structure.

This photograph of the WCS was taken from the Bybee Lake side of the structure during construction (dewatered). All stop logs are in place, and are visible above the reverse tide gates.

There is a staff gage on the Bybee side of the water control structure from which weekly or bi-monthly water-level readings are recorded during the cool-season water impoundment period. There is a permanent metal disc benchmark on the southwest concrete footing of the structure from which I based several of the elevation surveys. This benchmark is 13 feet (approximately 4 meters) above mean sea level (NGVD 1929).

The Lower Columbia River, Lower Willamette River, and the Columbia Slough in the Portland area experience twice daily tidal fluctuations. The average tidal range in the Willamette River in the vicinity of SBW is approximately 1.7 feet $(0.52 \mathrm{~m})$, with a spring range maximum of 2.2 feet $(0.67 \mathrm{~m}$, NOAA 2011$)$. During the twentieth century the hydrology of the Columbia River changed drastically due to dam regulation of flows. 
Hundreds of dams are now present on the Columbia River and its tributaries, mainly constructed for power generation and, to a much lesser extent, flood control. The first dam construction began in the 1930s. The Columbia River used to experience great variation between peak summer flows in May through June and low flows in the fall and winter months. Dam regulation reduced the magnitude of summer high flows and increased fall and winter flows, leading to a somewhat flattened annual discharge pattern (WSTB 2004).

Prior to 1982, the SBW area experienced greater seasonal fluctuations with spring freshets and summer-fall low water. In summer and fall months there was more area of exposed bottom and the associated vegetation. There was a band of young, living Salix surrounding the lower elevations of SBW wetland edges, and more mature Salix as well as Oregon ash forest at higher elevations (Fishman et al 1987, unpublished report). From 1982 until the fall of 2003, an earthen dam separated SBW from the North Slough. The dam was installed to reduce the occurrence of late-summer avian botulism. During this period, hydrology in SBW was primarily driven by precipitation and evapotranspiration and water levels generally remained higher than historic averages throughout the year. Emergent wetland and mudflat areas decreased and many Salix and Oregon ash communities were negatively affected due to consistently elevated water levels (Fishman et al. 1987, unpublished report). Following installation of the earthen dam, the vegetative community gradually changed, becoming more dominated by reed canarygrass (Phalaris arundinacea L., hereafter termed Phalaris) with less cover of willow scrub-shrub, water smartweed, and other native assemblages (Lev et al. 1994, Elaine Stewart, unpublished data). 
Currently, beaver activity in the permanent channel separating Bybee Wetland from Smith Wetland prevents full drainage of Smith Wetland. The approximate elevation of the beaver dam during the 2009 growing season was 7.51 feet $(2.29 \mathrm{~m})$ above mean sea level (NGVD 29). Although evaporation resulted in water levels lower than the dam elevation, this measured elevation at the beaver dam and several depth measurements at known locations were used to determine the lowest water levels achieved in Smith Wetland.

The area is home to numerous wildlife and plant species including osprey (Pandion haliaetus), bald eagle (Haliaeetus leucocephalus), beaver (Castor canadensis), black-tailed deer (Odocoileus hemionus), river otter (Lontra canadensis), Pacific chorus frogs (Pseudacris regilla), and over one hundred migratory and resident bird species. It houses an array of bottomland vegetation including water smartweed (Polygonum amphibium L.), Pacific willow (Salix lucida Muhl. ssp. lasiandra (Benth) E. Murray) forest, and Oregon ash (Fraxinus latifolia Benth.) forest assemblages (Lev et al. 1994, unpublished report). In addition, the wildlife area has one of the few remaining Oregon populations of Western painted turtle (Chrysemys picta bellii) and Columbia River sedge (Carex aperta Boott). Since the water control structure was installed, SBW has provided habitat to juvenile salmonids, including Fall Chinook (Oncorhynchus tshawytscha), Coho (O. kisutch), and Winter Steelhead (O. mykiss), which use the Wildlife Area for rearing and during migration (StreamNet 2010). 


\section{Phalaris arundinacea - Phenology and General Characteristics}

Phalaris is a cool-season, perennial grass that aggressively invades natural areas, resulting in a loss in native species diversity and altered ecosystem function. Phalaris can be found in much of Europe, Asia, and North America, extending as far north as Sweden and as far south as Southern California (Lavergne and Molofsky 2004). Merigliano and Lesica (1998) suggested that the invasive Phalaris populations in North America are either one or more imported varieties, hybrids between the native and one or more imported varieties, or hybrids between different imported varieties. Phalaris appears to be a cryptogenic species because its very early cultivation makes it difficult to determine its pre-agricultural status (Galatowitsch et al. 1999).

Phalaris generally flowers from May through September, but flowering can extend to December in mild climates (DiTomaso and Healy 2003). Phalaris can tolerate a wide range of hydrological conditions, can out-compete native species in a broad range of soil nutrient levels, and can alter biomass accumulation patterns in response to competition or changing conditions (Katterer and Andren 1999). Phalaris has a shallow but dense rhizomatous root system and produces an exceedingly high amount of aboveand below-ground biomass compared to other grass species. The impenetrable root system is mostly within the upper $20 \mathrm{~cm}$ of the soil surface and culms can reach over 6 feet in height (Stannard and Crowder 2001, Carlson et al. 1996). This growth habit prevents the establishment of other species and can shade out any seedlings of other species that do emerge.

Phalaris emerges early in the growing season, allowing it to accumulate biomass and form a canopy before many native species break dormancy. Further, Phalaris 
seedlings germinate in cool weather with low light conditions, allowing the species to quickly establish after a fall or winter disturbance (Lavergne and Molofsky 2004).

Phalaris is capable of producing relatively high amounts of above ground biomass during the establishment phase, out-competing other slower-growing species (Adams and Galatowitsch 2005). Phalaris appears to allocate even more energy to above ground growth when other species are present, exhibiting a large degree of phenotypic plasticity (Miller and Zedler 2003). After securing above ground space, Phalaris then devotes more energy to developing the extensive root system. This creates an enormous physical barrier to the germination of other seedlings both above and below ground (Adams and Galatowitsch 2005). Growth typically begins in the early spring (Stannard and Crowder 2001), although in mild climates like the Pacific Northwest, winter growth can occur. Peak growth rates occur in mid spring (Antieau 2003) with summer senescence in drought conditions or continued growth and tillering until the first hard frost if adequate water is available (Stannard and Crowder 2001).

Phalaris reproduces both vegetatively and sexually. Seeds remain dormant in warm, dry summer conditions and germinate in moist conditions when temperatures are 10-30 degrees C (DiTomaso and Healy 2003). However, except during introduction into a new or recently disturbed environment, it predominantly spreads through rhizomes that can produce numerous tillers throughout the growing season (Coops and van der Velde 1995). Barnes (1999) found that in less than 15 years, stands of Phalaris established $40 \%$ cover in previously un-invaded islands and shorelines of a river in Wisconsin. Phalaris produces many viable seeds which can remain dormant. Each inflorescence can 
produce as many as 600 seeds, which means that Phalaris quickly becomes an important part of the soil seed bank (Carlson et al. 1996).

Because Phalaris is such an invasive plant, it affects natural communities in many ways. Areas invaded by Phalaris often become monotypic stands of the species because the successional process is interrupted. Native species are quickly out-competed or prevented from reproducing. Phalaris has a strong negative correlation to native plant species diversity (Green and Galatowitsch 2002) and abundance among species (Schooler et al. 2006). Invasion by the species can negatively affect a variety of taxa (Spyreas et al. 2010). Phalaris, and the hydrological modification that often accompany infestations, can be devastating to sensitive or rare plant and animal species such as Howellia aquatilis (federally and state listed threatened, Lesica 1997), Carex aperta (state listed critically imperiled, Christy 2004), western painted turtle (state sensitive), and salmonids (various state and federal listings, Tanner et al. 2002, Henning et al. 2007). Phalaris also affects the physical environment it invades (Lavergne and Molofsky 2004). It increases sediment deposition, decreases soil microstructure, and reduces habitat micro-topography (Werner and Zedler 2002).

\section{Phalaris arundinacea - Response to Flooding and other Control Measures}

In light of Phalaris highly invasive character and community altering capacity, natural resources managers struggle to control it. Physical, chemical, and biological methods of control are employed to try to manage the species. Each of these control methods is associated with a certain amount of success; however, in combination, using an integrated pest management approach, the control is generally much greater (Lavergne and 
Molofsky 2004; Paveglio and Kilbride 2000). In any case, managers must pay close attention to surrounding (unmanaged) natural areas to assure that these control methods are not thwarted by continued propagule pressure.

Physical methods of Phalaris control include mechanical means such as cutting, mowing, digging out, or disking; burning; and flooding. Mechanical methods such as cutting and digging show the most success when employed early in the invasion process, when Phalaris stand size is still relatively small (Lavergne and Molofsky 2006). Burning of Phalaris stands is often not an effective method of control as the extensive root system can survive much fire damage and Phalaris seeds readily re-establish in the newly firedisturbed area. In areas that are fire adapted, native species may benefit from prescribed burning, allowing managers to control any Phalaris regrowth with less intensive methods. However, in many wetland areas, the native species are not fire-adapted, which means that without re-seeding they are not likely to establish after a burn (Henderson 1990). Flooding or the restoration of historic water regimes has shown mixed success as a means of controlling Phalaris and will be discussed later in greater detail. Gerard et al. (2008a) showed that the highest species diversity in a managed wetland was achieved when mowing and flooding were combined. They held that mowing provided opportunities for weak competitors that are normally shaded out by a few robust, generally graminoid species, while flooding provided a diverse seed source.

Each of the physical control methods can result in significant soil disturbances, which can leave the vegetative community open to re-invasion by Phalaris. Therefore, any physical methods employed may need to be conducted over multiple years and/or in combination with other methods to effectively exhaust the seed bank and root reserve as 
well as establish a native vegetative community (Paveglio and Kilbride 2000). While some studies show that re-establishment of native vegetation can occur through passive restoration (Leck 2003), other studies suggest otherwise. Hall and Zedler (2010) and Galatowitsch and van der Valk (1996) found that certain plant communities, such as sedge meadow and wet prairie, did not establish following restoration efforts, despite the close proximity of these communities to the restoration site. They concluded that to successfully re-establish the community, active restoration measures such as seeding or planting must take place.

Chemical control is often employed to control Phalaris. There are many kinds of herbicides and several methods of herbicide use. Herbicides can be pre-emergent, postemergent, selective, or general and can be applied in spot or broadcast applications. Spot application of herbicides is time-consuming and labor intensive and therefore rarely employed in situations other than small infestations or extremely sensitive areas (such as listed species habitat). Broadcast application is generally preferred when large, nearly monotypic stands of a species are present. Pre-emergent chemicals act on plant tissue prior to germination or dormancy break. These chemicals are generally non-selective and long-lasting and can have a significant impact on the entire community. Post-emergent herbicides are somewhat better because they begin to act on the first species that starts to grow. Phalaris generally emerges and/or germinates earlier than most species so a postemergent herbicide can be largely used up prior to native seedlings emerging (depending on the longevity of the herbicide and the amount that was applied). Both pre- and postemergent herbicides are generally broadcast over an entire area where the target species 
occurs because, unless the target species is carefully mapped or the last year's growth is still visible, there is no way to accurately spot apply these chemicals.

Selective herbicides target only a certain class of plants such as dicots or monocots. The more selective an herbicide, the less off-target impacts will result. Selective herbicides (such as Dalapon) are broadcast or spot applied depending on the severity of the infestation. Currently, there are no herbicides available that control only Phalaris; however, there are several graminoid specific herbicides that show mixed success. Healy and Zedler (2010) found that although Phalaris died back initially following application of sethoxydim (graminicide), it regained dominance by the end of the growing season through regeneration via rootstock and/or germination of seeds from the extensive seed bank.

General herbicides are non-selective, meaning they will damage or kill any plant tissue with which it comes into contact. General herbicides are best used in spot applications or broadcast application over monotypic stands to minimize off-target kill (Lavergne and Molofsky 2006). Timing of application of the general herbicide glyphosate, a commonly used chemical in wetland and aquatic systems, is a critical consideration. When applied early in the growing season, it has the potential to do the least damage to native species that have not yet emerged. However, during the early season the herbicide is not translocated as well as in fall applications and regrowth from rhizomes may occur. Late season applications are more effective in damaging the entire plant system of Phalaris as it is more readily transported to the root system; however, it is also likely to do the most damage to the native community through off-target effects (Adams and Galatowitsch 2006). 
Currently, there are no classical biological control vectors available for Phalaris control. There are certain viruses, fungi, insects, and herbivores that attack Phalaris; however, they are generalist species that are known to attack many other plant species and thus do not satisfy the rigorous criteria for employing biological control (Lavergne and Molofsky 2006). Because the older tissue of most varieties of Phalaris contain high alkaloid levels (making them unpalatable to most herbivores), they have a natural resistance to predation (Ostrem 1987). Another method of biological control is establishing species that can compete with Phalaris. This has been employed with competitive annual and perennial cover crops such as barnyard-grass and knotweed species (Perry and Galatowitsch 2003) as well as with competitive cool-season native species (Lindig-Cisneros and Zedler 2002). In addition, Phalaris is known as a shadeintolerant species (Cooke 1997), so planting shade-producing trees with year-round growth or cool season leaf emergence may provide a level of control. Kim et al. (2006) found that high density Salix stake plantings dramatically reduced the cover of Phalaris after only a single season. Generally, competition- or shade-based methods of biological control must be employed in combination with other methods of control to allow the successful germination and establishment of these species which is generally not possible with an intact, monotypic stand of Phalaris (Lavergne and Molofsky 2006).

The most successful Phalaris control efforts to date include those that utilize several methods concurrently or sequentially. This strategy, known as integrated pest management (IPM), is defined by the Environmental Protection Agency as follows:

"An effective and environmentally sensitive approach to pest management that relies on a combination of common-sense practices. IPM programs use current, 
comprehensive information on the life cycles of pests and their interaction with the environment and available pest control methods to manage pest damage by the most economical means and with the least possible hazard to people, property, and the environment."

Kilbride and Paveglio (1999) and Paveglio and Kilbride (2000) demonstrated a mixedmanagement strategy at the Ridgefield National Wildlife Refuge in southern Washington. They used physical methods such as disking and hydrological manipulation as well as chemical control to successfully control Phalaris (79-99\% reduction in three years) and re-establish a diverse native community. Lavergne and Molofsky (2006) support the notion that an integrated management technique is required when dealing with infestations of Phalaris. They held that active restoration of the native community structure and composition must accompany chemical, physical, and hydrological controls to sufficiently deal with Phalaris in restoration projects.

Restoration of historic flooding regimes, or when true restoration is not possible, water-level management to mimic natural flooding regimes, can both benefit native plant communities while inhibiting undesirable species (Harris and Marshall 1963; Michener and Haeuber 1998). Flooding has shown mixed success as a means of controlling Phalaris. Nygaard and Ejrnaes (2009) found that when productivity (nutrients) remains high, restoring hydrology alone is unlikely to result in a species-rich wetland. Some studies have found that flooding results in increased vegetative growth, tillers, and nodes (Lefor 1987, Rice and Pinkerton 1993, Coops et al. 1996). Kercher and Zedler (2004a) found that Phalaris outgrew all other perennial species in four different flood regimes and had the greatest amount of root air space of all the species studied. Other studies have shown decreased above- and below-ground biomass and stem density with flooding 
as shallow as 5 to $30 \mathrm{~cm}$ (Coops et al. 1996, Miller and Zedler 2003). Cooke (1997) asserted that Phalaris will not persist under water for an entire season. Coops and van der Velde (1995) found that Phalaris germinated and grew best in exposed/drained soils, and that growth slowed or stopped under submerged conditions. Although growth of Phalaris slows or stops under flood conditions, the species appears to survive, at least when periods of inundation are short (days or weeks) (Barclay and Crawford 1982).

Establishing the correct depth and duration of flooding is extremely important because in certain flood conditions, Phalaris can actually be stimulated to grow while the native species are damaged (Paveglio and Kilbride 2000, Kercher and Zedler 2004b, Jenkins et al. 2008). Miller and Zedler (2003) found that longer duration of flooding resulted in fewer Phalaris shoots, while shorter duration, cyclical flooding produced more and larger shoots. Molofsky et al. (1999) found that above ground biomass production differed depending on the month in which high soil moisture was present.

In the Pacific Northwest, Paveglio and Kilbride (2000) found that depths of $50 \mathrm{~cm}$ over a three year period were effective at nearly eliminating Phalaris and establishing a native emergent community when combined with other methods of control. Jenkins et al. (2008), the progenitor of this study, found that after just one year, areas inundated through the spring and early summer to depths of $85 \mathrm{~cm}$ showed a reduction in Phalaris cover. In both local cases, the flood control was implemented to hold water through early summer. The present study described herein focused on spring and summer flooding to achieve control of Phalaris and benefit native vegetation communities. 


\section{Other Important Flora - Phenology and Response to Flooding}

The objective to increase native plant cover and diversity, coupled with the goal to reduce Phalaris cover, is a further goal of hydrologically-based management at SBW. In fact, this goal is common to wetland and floodplain restorations (Gerard et al. 2008b, Spyreas et al. 2010, Ward et al. 1999). Important to this objective are considerations of how the desired native community responds to the new water regime, including if species phenology and physiological tolerances favor the restored hydrology. Some wetland species are well adapted to germinate in flooded conditions, others delay germination until the risk of flooding has subsided for the year based on light availability, temperature, moisture, or photoperiod (Crawford 2003, Rathcke and Lacey 1985). If the flooded period is extensive and/or a species requires more non-flooded time for expression of the full phenological cycle, certain species are not likely to persist.

The following text includes a review of the available literature on Polygonum amphibium, P. persicaria, Bidens cernua, Ludwigia palustris, Veronica americana, Salix lucida (all species with significant percent cover), B. frondosa, Carex aperta (both locally rare but important species), Iris pseudacorus, and Lythrum salicaria (both invasive species). Where little or no information existed for a particular species, I used genus level considerations and/or personal communications with local botanical experts. The phenological timing and expected response to flooding is summarized in Table 1. 
Table 1: Phenology and Flood Tolerance of Key Species.

The table provides a summary of vegetative growth timing, flowering period, and expected response to flooding of species important to the study.

\begin{tabular}{|c|c|c|c|}
\hline Species & Growth Phase & Potential Duration & $\begin{array}{l}\text { Expected Response to } \\
\text { Flooding }\end{array}$ \\
\hline \multirow[t]{2}{*}{ Bidens cernua $^{1}$} & Vegetative & May-December & \multirow[t]{2}{*}{ Positive, mixed } \\
\hline & Flowering & June-November & \\
\hline \multirow[t]{2}{*}{ Bidens frondos $a^{2}$} & Vegetative & No Data & \multirow[t]{2}{*}{ Unknown } \\
\hline & Flowering & May-September & \\
\hline \multirow[t]{2}{*}{ Carex aperta ${ }^{3}$} & Vegetative & No Data & \multirow[t]{2}{*}{ Positive } \\
\hline & Flowering & February-April & \\
\hline \multirow[t]{2}{*}{ Iris pseudacorus $^{4}$} & Vegetative & Year-Round & \multirow[t]{2}{*}{ Positive } \\
\hline & Flowering & March-November & \\
\hline \multirow[t]{2}{*}{ Ludwigia palustris ${ }^{5}$} & Vegetative & March-November & \multirow[t]{2}{*}{ Negative } \\
\hline & Flowering & July-September & \\
\hline \multirow[t]{2}{*}{ Lythrum salicaria $^{6}$} & Vegetative & April-November & \multirow[t]{2}{*}{ Positive } \\
\hline & Flowering & June-September & \\
\hline \multirow[t]{2}{*}{ Phalaris arundinacea $^{7}$} & Vegetative & Year-Round & \multirow[t]{2}{*}{ Negative } \\
\hline & Flowering & May-December & \\
\hline \multirow[t]{2}{*}{ Polygonum amphibium 8} & Vegetative & March-November & \multirow[t]{2}{*}{ Positive } \\
\hline & Flowering & June-November & \\
\hline \multirow[t]{2}{*}{ Polygonum persicaria9 } & Vegetative & March-November & \multirow[t]{2}{*}{ Positive } \\
\hline & Flowering & March-November & \\
\hline
\end{tabular}

${ }^{1}$ Mitchell 1976, Keddy \& Ellis 1984, Guard 1995, Weiher 1996, Cooke 1997, Brandel 2004a, Kercher \& Zedler 2004, Gratani et al. 2008, Jenkins et al. 2008, Gratani et al. 2009

${ }^{2}$ Guard 1995, Jenkins et al. 2008, Stewart 2010

${ }^{3}$ Moog \& Janiesch 1990, Guard 1995, Galatowitsch \& van der Valk 1996, Cooke 1997, Christy 2004, Wilson et al. 2008, Hall \& Zedler 2010, Stewart 2010

${ }^{4}$ Guard 1995, Cooke 1997, DiTomaso \& Healy 2003

${ }^{5}$ Barclay \& Crawford 1982, Sutherland 1990, Hanhijarvi \& Fagerstedt 1994, Coops \& van der Velde 1995, Guard 1995, Cooke 1997, Jenkins et al. 2008

${ }^{6}$ Shamsi \& Whitehead 1974, Keddy \& Ellis 1984, Guard 1995, Cooke 1997, Shadel \& Molofsky 2002, DiTomaso \& Healy 2003, Dech \& Nosko 2004, Fraser \& Karnezis 2005, Schooler 2006, Montague et al. 2007

${ }^{7}$ Lefor 1987, Rice \& Pinkerton 1993, Coops \& van der Velde 1995, Coops et al. 1996, Cooke 1997, Katterer \& Andren 1999, Kilbride \& Paveglio 1999, Molofsky et al. 1999, Stannard \& Crowder 2001, Antieau 2003, DiTomaso \& Healy 2003, Miller \& Zedler 2003, Kercher \& Zedler 2004a, Lavergne \& Molofsky 2004, Gerard et al. 2008a, Jenkins et al. 2008, Nygaard \& Ejrnaes 2009

${ }^{8}$ Mitchell 1976, Carter \& Grace 1990, Cooke 1997, Partridge 2001, DiTomaso \& Healy 2003, Jenkins et al. 2008

${ }^{9}$ Simmonds 1945, Timson 1964, Mitchell 1976, Sultan \& Bazzaz 1993, Cooke 1997, DiTomaso \& Healy 2003, Jenkins et al. 2008 
Table 1: Phenology and Flood Tolerance of Key Species.

The table provides a summary of vegetative growth timing, flowering period, and expected response to flooding of species important to the study.

\begin{tabular}{|l|c|c|c|}
\hline \multicolumn{1}{|c|}{ Species } & Growth Phase & Potential Duration & $\begin{array}{c}\text { Expected Response to } \\
\text { Flooding }\end{array}$ \\
\hline Salix lucida & Pegetative & April-November & Positive \\
\cline { 2 - 3 } & Flowering & March-June & \\
\hline Veronica species $^{11}$ & Vegetative & No Data & Positive \\
\cline { 2 - 3 } & Flowering & May-July & \\
\hline
\end{tabular}

There are several species of Polygonum (hereafter, generic Polygonum species is referred to as Polygonum) found within the SBW area including the native P. amphibium, P. hydropiperoides, and P. lapathifolium, and the non-native $P$. hydropiper and $P$. persicaria. Generally, Polygonum does well in flooded conditions, with P. amphibium perhaps even preferring flooded conditions (Mitchell 1976). Polygonum increased in cover the first year after managed flooding was initiated in the Jenkins et al. (2008) study.

Polygonum amphibium is a perennial aquatic to semi-aquatic species reproducing via seeds and vegetatively through rhizomes or stolons (Cooke 1997). Shoot growth begins in March or early April in Britain (Partridge 2001). Above-ground tissue senesces at the first frost of the cold season, with underground rhizomes persisting. Flowering generally occurs from June through October. Seeds require a cold moist period to break dormancy in the first or second spring following flowering (DiTomaso and Healy 2003, Partridge 2001). However, studies indicate that the species primarily reproduces vegetatively, often forming dense monotypic stands derived from one to a few clones (Carter and Grace 1990, Partridge 2001). The species allocates more energy to

\footnotetext{
${ }^{10}$ Guard 1995, Cooke 1997, Crawford 2003, Kuzovkina-Eischen 2003, Timoney \& Argus 2006, Jenkins et al. 2008

${ }^{11}$ Sain et al. 1984, Guard 1995, Cooke 1997, Jenkins et al. 2008
} 
vegetative growth and spread than sexual reproduction, with seeds being produced and germinating only rarely (Partridge 2001). Carter and Grace (1990) showed that $P$. amphibium had more root and shoot growth in flooded conditions, and performed poorly when compared to other species of Polygonum in drained conditions. Partridge (2001) demonstrated that $P$. amphibium adapted very well to fluctuating water levels.

The non-native $P$. persicaria is an annual aquatic to semi-aquatic species with spring germination (early April) and senescence at the first frost (Simmonds 1945, DiTomaso and Healy 2003). Flowering generally occurs from May through September (Simmonds 1945) with accounts of flowering extending from as early as March (Cooke 1997) to as late as November (DiTomaso and Healy 2003). Seeds are set from June or July until senescence (Simmonds 1945). Seeds can remain viable and dormant for up to 20 years but generally germinate the following spring once dormancy has been broken with cold, moist conditions (Timson 1964). P. persicaria showed a high degree of phenotypic plasticity in relation to reproductive success in a variety of moisture regimes in a 1993 study by Sultan and Bazzaz.

Bidens cernua and B. frondos $a$ are both important emergent species that increased in cover at SBW following initiation of water management (Jenkins et al. 2008). B. frondosa can be a locally important egg attachment site for amphibians (Stewart 2010). B. cernua is an annual species with a total phenological cycle, from seedling emergence to senescence, lasting just over 200 days in Italian sites (Gratani et al. 2008, Gratani et al. 2009). Germination occurred in May when mean daily maximum and minimum temperatures were approximately $17 \mathrm{C}$ and $12.5 \mathrm{C}$, respectively (Gratani et al. 2008). In another study, germination occurred after a period of dormancy when temperatures were 
above 15C (Brandel 2004). Brandel (2004) found that light greatly increased germination and that seeds died that were buried for more than 20 months. In the Pacific Northwest, sources note that B. cernua flowers from July through September (Guard 1995, Cooke 1997) and B. frondosa from June through October (Guard 1995). The total length of the reproductive period, including flowering and fruiting, from the Italian sites was 106 days, with flowering beginning in August, seed development beginning towards the end of September, and seed dispersal beginning in mid-October (Gratani et al. 2008).

Although seeds of B. cernua may require flooding or at least moist conditions to break dormancy (Gratani et al. 2008), germination was negatively correlated with increasing water depth in a Keddy and Ellis (1984) study. A Weiher et al. (1996) study showed that B. cernua was a dominant species in a seasonally flooded treatment experimental wetland for the five years it was studied. A Kercher and Zedler (2004) study showed that B. cernua was moderately tolerant of flooding and was a rapid colonizer of moist, open mudflats.

Ludwigia palustris is a native, semi-aquatic, perennial species with stems that root readily at nodes in contact with soil surfaces (Cooke 1997). Shoots appear from rootstock in the mid-spring (Guard 1995) and flowering occurs from July through September (Guard 1995, Cooke 1997). L. palustris is noted to be tolerant of a variety of water levels (Guard 1995). The first year following initiation of water management at SBW, L. palustris showed a decrease in overall cover (Jenkins et al. 2008).

Veronica americana is a native, perennial, rhizomatous species (Cooke 1997). It blooms from May through July (Guard 1995, Cooke 1997). When a formerly dammed lake site was drained in Virginia, V. americana was among the early pioneers (June) on 
the emergent soil surface, but was absent from later samples in July and October when overall percent cover of plants was higher and only a few species were dominant (Sain et al. 1984). The first year after initiation of water management at SBW, V. americana increased in cover (Jenkins et al. 2008).

The native Salix lucida is a highly branched, perennial, tall shrub to tree species that can become quite large, with trunks up to $60 \mathrm{~cm}$ thick (Cooke 1997). Salix are pioneering species that are well adapted to disturbances and a variety of ecological conditions. They prefer moist or wet habitats that are not flooded for extended periods. Generally, Salix are shade intolerant with short-lived seeds that require full sun and moisture for germination (Timoney and Argus 2006). Leaves emerge in the spring with (Cooke 1997) or just before (Guard 1995) flowering, which occurs from mid-April through mid-May (Cooke 1997).

As a genus, Salix is generally tolerant of some flooding but can show a wide variety of responses to anaerobic conditions (Kuzovkina-Eischen 2003). At SBW, Salix lucida increased in cover after one year of managed flooding (Jenkins et al. 2008). Timoney and Argus (2006) studied Salix species responses to changes in water levels extensively at the Peace-Athabasca Delta. They found that Salix species generally died back during extended periods of high water and went through establishment phases during drier periods. Older individuals tended to fare better in flooded conditions; however, all age groups died back when wet periods were common (i.e. several wet years in a row) and/or more recent, deeper, and of longer duration. They noted that water conditions varied much more frequently than Salix species cover variations, indicating that cover at a given time is more a reflection of water conditions on the decade scale 
than contemporaneously (Timoney and Argus 2006). Crawford (2003) found that many tree species in cool oceanic climates like the Pacific Northwest do not fare well in flooded conditions. In flooded conditions, trees slowly die due to root carbohydrate reserve depletion coupled with post-anoxic stress.

Lythrum salicaria is a rhizomatous perennial that spreads via seeds, runners, and/or stem fragments. It is an invasive wetland plant species in the United States, capable of reducing species diversity (Schooler 2006). It is well adapted to disturbance and capable of germinating from seed and flowering in as little as 8 to 10 weeks (Shamsi and Whitehead 1974, Shadel and Molofsky 2002). Although germination can occur throughout the growing season (Shadel and Molofsky 2002, Montague et al. 2007), it typically occurs in mid spring through early summer (DiTomaso and Healy 2003). Vegetative growth from overwintering root stock emerges in late spring (Shadel and Molofsky 2002, Montague et al. 2007). Flowering can range from June through October (DiTomaso and Healy 2003, Dech and Nosko 2004, Montague et al. 2007) but primarily occurs from July until September in the Pacific Northwest (Guard 1995, Cooke 1997). Some sources state that the species does not tolerate flooding during the growing season (DiTomaso and Healy 2003, Fraser and Karnezis 2005) while others indicate that it does well in or even prefers shallow inundation (Keddy and Ellis 1984, Cooke 1997).

Iris pseudacorus is a perennial species that reproduces via thick rhizomes and hardy seeds. It is considered here because it is an invasive wetland plant in the Pacific Northwest (Guard 1995, Cooke 1997, DiTomaso and Healy 2003). In areas with mild winters aboveground plant tissue can persist year-round; however most vegetative growth 
occurs in April through June (Sutherland 1990). Flowering can occur for extended periods, but generally takes place from April through August (Guard 1995, Cooke 1997). I. pseudacorus can survive but shows limited growth under flooded conditions (Barclay and Crawford 1982, Sutherland 1990). Germination occurs exclusively on drained soil where optimal growth is also realized (Coops and van der Velde 1995). However, local sources indicate that it is commonly found in standing water of under 0.5 meters (Cooke 1997). Further, one study showed that I. pseudacorus not only tolerated flooding but also resumed normal growth after periods of anoxia, especially when they occurred in winter or cold-season months (Hanhijarvi and Fagerstedt 1994).

Carex aperta is a perennial, rhizomatous species found in only a few, largely disturbed locations in the Columbia River floodplain (Wilson et al. 2008). It is considered here because of its relative rarity and ecological significance. Formerly extensive populations have been greatly reduced due to hydrologic changes associated with flow regulation of the Columbia River. When established, it can persist in areas dominated by Phalaris (Christy 2004, Wilson et al. 2008). It has also persisted in areas that are too wet for Phalaris in the Columbia River bottomlands (Christy 2004). It is described as flowering and fruiting during the early spring, with most of the seeds distributed by late spring (Guard 1995); however, local experts suggest the flowering period can extend until much later in the growing season based on when flood conditions recede (Elaine Stewart, personal communication).

Christy (2004) describes the habitat of C. aperta as being flooded into the early summer and dry by mid- to late-summer. In general, Carex species are tolerant of flooding; most Carex species in our region are considered obligate or facultative wetland 
species (Guard 1995, Cooke 1997). Moog and Janiesch (1990) describe root adaptations and other morphological features that allow Carex species to tolerate flooded conditions; however, they also note that flood tolerance is variable among the genus and depends on the species. When Hall and Zedler (2010) studied hydrological restoration in the prairie pothole region, they found that Carex seed banks had been depleted in areas dominated for several years by the invasive Typha latifolia. The Carex community was able to spread vegetatively, but did not re-establish significantly through the seed bank.

Research conducted by Galatowitsch and van der Valk (1996) in the same region showed that restored wetlands contained approximately half of the species found in natural wetlands, especially when it came to sedge (Carex) meadow species.

Based on the information gathered from published literature and local experts, I developed Figure 4 showing the phenology of important species. There was no literature available regarding the vegetative growth period of B. frondosa, C. aperta, or Veronica species. The vegetative growth period of $B$. frondosa is likely similar to B. cernua as both are annual, facultative wetland $(\mathrm{FACW}+)$ species of the same genus. 


\begin{tabular}{|c|c|c|c|c|c|c|c|c|c|c|c|c|c|}
\hline Species & Growth & Jan & Feb & Mar & Apr & May & Jun & Jul & $\mathrm{Au}$ & Sep & Oct & Nov & Dec \\
\hline \multirow{2}{*}{$\begin{array}{l}\text { Bidens } \\
\text { cernua }\end{array}$} & Vegetative & & & & & & & & & & & & \\
\hline & Flowering & & & & & & & & & & & & \\
\hline \multirow{2}{*}{$\begin{array}{l}\text { Bidens } \\
\text { frondosa } \\
\end{array}$} & Vegetative & $*$ & \multicolumn{4}{|c|}{ *No Data Available } & * & $*$ & $*$ & $*$ & $*$ & $*$ & $*$ \\
\hline & Flowering & & & & & & & & & & & & \\
\hline \multirow{2}{*}{$\begin{array}{l}\text { Carex } \\
\text { aperta }\end{array}$} & Vegetative & $*$ & \multicolumn{4}{|c|}{ *No Data Available } & * & $*$ & $*$ & $*$ & $*$ & $*$ & $*$ \\
\hline & Flowering & & & & & & & & & & & & \\
\hline \multirow{2}{*}{$\begin{array}{l}\text { Iris } \\
\text { pseudocorus }\end{array}$} & Vegetative & & & & & & & & & & & & \\
\hline & Flowering & & & & & & & & & & & & \\
\hline \multirow{2}{*}{$\begin{array}{l}\text { Ludwigia } \\
\text { palustris }\end{array}$} & Vegetative & & & & & & & & & & & & \\
\hline & Flowering & & & & & & & & & & & & \\
\hline \multirow{2}{*}{$\begin{array}{l}\text { Lythrum } \\
\text { salicaria }\end{array}$} & Vegetative & & & & & & & & & & & & \\
\hline & Flowering & & & & & & & & & & & & \\
\hline \multirow{2}{*}{$\begin{array}{l}\text { Phalaris } \\
\text { arundinacea } \\
\end{array}$} & Vegetative & & & & & & & & & & & & \\
\hline & Flowering & & & & & & & & & & & & \\
\hline \multirow{2}{*}{$\begin{array}{l}\text { Polygonum } \\
\text { amphibium }\end{array}$} & Vegetative & & & & & & & & & & & & \\
\hline & Flowering & & & & & & & & & & & & \\
\hline \multirow{2}{*}{$\begin{array}{l}\text { Polygonum } \\
\text { persicaria }\end{array}$} & Vegetative & & & & & & & & & & & & \\
\hline & Flowering & & & & & & & & & & & & \\
\hline \multirow[b]{2}{*}{ Salix lucida } & Vegetative & & & & & & & & & & & & \\
\hline & Flowering & & & & & & & & & & & & \\
\hline \multirow{2}{*}{$\begin{array}{l}\text { Veronica } \\
\text { species } \\
\end{array}$} & Vegetative & $*$ & *No & Data & & lable & $*$ & $*$ & $*$ & $*$ & $*$ & $*$ & $*$ \\
\hline & Flowering & & & & & & & & & & & & \\
\hline
\end{tabular}

Figure 4: Vegetative Growth and Flowering Period for Important Taxa.

The vegetative growth and flowering periods shown in the figure are based on all available literature ${ }^{12}$. Black shading indicates the growth period is strongly supported by literature and/or local experts. Grey shading indicates the growth period is reported by fewer sources and/or is based on research from different regions. When available, literature sources based on populations from the Pacific Northwest were weighted more than sources from other regions.

\footnotetext{
${ }^{12}$ Selected references: Simmonds 1945, Timson 1964, Shamsi and Whitehead 1974, Mitchell 1976, Barclay and Crawford 1982, Keddy and Ellis 1984, Sain et al. 1984, Lefor 1987, Carter and Grace 1990, Moog and Janiesch 1990, Sutherland 1990, Rice and Pinkerton 1993, Sultan and Bazzaz 1993, Hanhijarvi and Fagerstedt 1994, Coops and van der Velde 1995, Guard 1995, Galatowitsch and van der Valk 1996, Coops et al. 1996, Weiher 1996, Cooke 1997, Katterer and Andren 1999, Kilbride and Paveglio 1999, Molofsky et al. 1999, Partridge 2001, Stannard and Crowder 2001, Shadel and Molofsky 2002, Crawford 2003, DiTomaso and Healy 2003, Kuzovkina-Eischen 2003, Miller and Zedler 2003, Brandel 2004a, Christy 2004, Dech and Nosko 2004, Kercher and Zedler 2004, Lavergne and Molofsky 2004, Fraser and Karnezis 2005, Schooler 2006, Timoney and Argus 2006, Montague et al. 2007, Gerard et al. 2008a, Gratani et al. 2008, Jenkins et al. 2008, Wilson et al. 2008, Gratani et al. 2009, Nygaard and Ejrnaes 2009, Hall and Zedler 2010, Stewart 2010
} 


\section{This Study}

This thesis on the work I conducted at SBW is part of an ongoing project to assess the effectiveness of water management, or controlled flooding, on Phalaris and native bottomland plant communities. Upon acquiring the property in the early 1990's, Metro Regional Government began to develop a long-term management plan for the site, which included water management and regular vegetation monitoring. In 2003, Elaine Stewart, natural resources scientist at Metro, plus Portland State University graduate student Noah Jenkins and environmental science professor Alan Yeakley developed the original study design for the project that would determine if water management produced the desired results in the very early stages of implementation. Noah's graduate work included an assessment of the baseline vegetation conditions as well as the vegetation conditions during the first growing season after water management began. My work for the project assesses the fifth- and sixth-year vegetation conditions. Both Noah and I aimed to contribute to the literature relating to the flood management of Phalaris and native bottomland species. Metro intends to continue to monitor the hydrology of SBW annually and the vegetation at least every five years. This long term study has and will continue to provide valuable information on natural resources management.

\section{Annual Water Management}

The annual water management regime at SBW, implemented by Metro Regional Government, is intended to:

- $\quad$ Control Phalaris by inundating during the cool-season growth period; 
- Support native emergent and bottomland hardwood communities through annual warm-season draw-down;

- $\quad$ Provide off-channel rearing, refugia, and migration habitat for salmonids during the winter and spring;

- $\quad$ Expose mudflats for shorebirds migrating in mid- to late-summer;

- $\quad$ Provide winter waterfowl habitat, including food resources for dabbling ducks.

The water control structure between Bybee Wetland and the North Slough holds water from rainfall and high tides in SBW starting in the late fall until the late spring or early summer of the following year. The structure itself is approximately 13 feet ( 4 meters) above mean sea level (NGVD 29), so this is the maximum possible water depth that can be maintained in the area without flooded conditions above this level in the North Slough. Based on recommendations by Jenkins (2005), Metro managers maintain the maximum possible levels in SBW to inundate areas susceptible to or already invaded by Phalaris during its cool-season growth period, and thus suppress its growth during this period. Jenkins (2005) found that at least 0.85 meters of inundation was necessary to reduce the abundance of Phalaris and that in areas with less than 0.85 meters of inundation, Phalaris showed an increase in cover.

In the spring, water stop-logs in the water control structure are removed incrementally until the water levels within SBW are the same as those in the North Slough. This spring and summer draw-down steadily exposes areas of mudflat during a time period in which native species emerge (see phenological descriptions above), removing the competitive advantage Phalaris holds without the suppression resulting from winter and spring inundation. The stop-logs are removed so that draw-down is slow 
enough to provide ideal conditions for native plant emergence but quickly enough so that salmonids will avoid entrapment.

Table 2 shows the actual water management regime employed each year since the water control structure was installed (2004 through 2009). Depending on the amount of rainfall each year, the maximum water elevation, duration of flooding, and draw-down process is variable from year to year. During each growing season, SBW manager Elaine Stewart begins draw-down by removing stop-logs from the WCS. The rate of draw-down is variable, depending on when it begins and how frequently additional stop-logs are removed. The goal is to have SBW at the same level as the Columbia Slough by midsummer (i.e., all stop-logs removed). However, draw-down cannot commence until SBW water levels are low enough to allow access to the WCS. In years with spring flooding, high water persists in SBW for longer duration and results in a faster rate of draw-down once access to the WCS is possible.

Table 2: Water Management Summary.

Shown is a summary of the specific water management regime from 2004 through 2009 . The information in this table was used to determine the maximum depth and duration of flooding for each study year.

\begin{tabular}{|c|c|c|c|c|}
\hline Water Year & $\begin{array}{c}\text { Maximum Water } \\
\text { Elevation (meters) }\end{array}$ & $\begin{array}{c}\text { Date of Maximum } \\
\text { Elevation (meters) }\end{array}$ & Start Drawdown & End Drawdown \\
\hline $2003 / 2004$ & 3.3 & March 2, 2004 & May 10, 2004 & July 28, 2004 \\
\hline $2004 / 2005$ & 3.2 & May 23, 2005 & May 23, 2005 & August 5, 2005 \\
\hline $2005 / 2006$ & 4.5 & January 3, 2006 & June 2, 2006 & August 31, 2006 \\
\hline $2006 / 2007$ & 3.7 & March 3, 2007 & June 4, 2007 & August 16, 2007 \\
\hline $2007 / 2008$ & 4.3 & May 27, 2008 & July 8, 2008 & August 13, 2008 \\
\hline $2008 / 2009$ & 3.7 & February 8, 2009 & June 23, 2009 & August 18, 2009 \\
\hline
\end{tabular}




\section{Research Questions and Hypotheses}

With my research, I addressed the following questions:

1. Is it possible to consistently alter the annual SBW hydrology to reflect the historic pattern of spring high water and late summer drying with the water control structure?

2. To what extent and in what landscape position does the water management regime change the abundance of Phalaris?

3. Are there areas where Phalaris or other non-desirable species have increased in abundance?

4. To what extent and in what landscape position does the water management regime change the abundance of native bottomland and emergent plant species?

5. Are there areas where native vegetation has decreased in abundance?

6. What, if any, interactions between vegetation, elevation, and/or depth and duration of flooding can be determined from the pool of project data?

I tested the following hypotheses:

1. If hydrology is managed in SBW through the WCS, the annual hydrology will reflect the historic hydrograph pattern of spring high water and summer drying more than prior to water management.

2. If hydrology is managed in SBW through the WCS for 5 or more years, overall Phalaris abundance will be lower than the baseline abundance (2003) and first year response (2004).

3. If hydrology is managed in SBW through the WCS, Phalaris cover in areas not experiencing enough depth or long enough duration of inundation will increase significantly.

4. If hydrology is managed in SBW through the WCS for 5 or more years, vegetation will become distributed in zones distinct from baseline conditions based on local hydrology.

5. If hydrology is managed in SBW through the WCS for 5 or more years, vegetation will have stabilized as reflected in a Shannon Diversity index value similar to the pre-water management value.

6. If hydrology is managed in SBW through the WCS for 5 or more years, vegetation in areas experiencing the longest depth and duration of inundation will shift from facultative wetland species to obligate wetland species. 


\section{Chapter 2: Methods}

\section{Study Design and General Methods}

My study design and data collection methods are based upon those established in 2003 by Noah Jenkins, supervised by Alan Yeakley and Elaine Stewart (Jenkins 2005, Jenkins et al. 2008). He developed a study to track vegetation changes resulting from the new hydrological regime initiated during the fall of 2003. The methods generally conform to those established during the Jenkins et al. study (2008) with exceptions noted.

Vegetation sampling locations are along linear transects located perpendicular to and along the annual waterline of SBW (Figure 2). The transect locations were initially demarcated in the fall of 2003, prior to WCS installation, to collect a baseline of vegetation data prior to initiation of water management in SBW. Jenkins (2005) collected vegetation data along 30 transects in the fall of 2003, prior to WCS installation, and vegetation and elevation data in the fall of 2004 along these transects. Jenkins (2005) also collected phenological data for Phalaris during the 2004 growing season. I collected vegetation data along 26 of the original 30 transects in 2008 and 2009 and determined elevation for these transects in the fall of 2010. As with the previous study, I correlated the elevation data to water-level data taken weekly at the water-control structure to determine the depth and duration of flooding for the length of the transects. One of the few deviations from the Jenkins (2005) study is that I used only 26 of the original 30 transects to document vegetation changes. Another is that I did not look at the effects that the water management regime had on the vigor of Phalaris. A further difference is 
that I examined responses for two consecutive years (rather than just one year) after a much longer management period.

I compared the baseline vegetation data to the vegetation data collected after the new hydrological regime was established to assess the effects of such a water regime. I looked specifically at Phalaris and other important Columbia River bottomland vegetation species and communities. The ultimate goal was to determine if managed flooding and/or hydrological restoration is an effective means of Phalaris control and native vegetation enhancement.

\section{Study Design}

\section{Transect Point Selection and Location}

The Jenkins study (2005) originally selected and field-identified points for transect locations. He created a shapefile (ArcView 3.2) of the 50 meter wide area around the open water portion of SBW as seen on a 2001 aerial photograph. This 50 meter wide band was the area inside of which Phalaris was most prevalent and the new managed flooding regime would have most impact. He then established a 10 by 10 meter grid within the band area, giving each grid cell a numerical code. He entered and randomized the grid cell codes into an Excel file. From the randomized list, he selected the first 30 grid cell points that were not omitted due to practical or physical constraints. Using the decimal latitude and longitude (5 decimal places) provided by ArcView, Jenkins (2005) field-located the selected grid cell points using a GPS unit (Trimble TDC 1 Asset Surveyor, 1 meter accuracy). The average position dilution of precision (PDOP) for 
field-location of cell points was 2.77, which the Los Alamos National Laboratory (2003) considers "excellent."

\section{Transect Marking Procedure}

Once field-located, Jenkins (2005) marked each of the 30 transect's grid cell points with a $1.2 \mathrm{~m}$ rebar stake. He then created each linear transect by extending a line perpendicularly from the water's edge through the grid cell point, ending in an upland location assumed to remain dry during high water periods (approximately $3.4 \mathrm{~m} \mathrm{NGVD}$ 29). From the grid cell point to the water's edge, he recorded the compass direction and slope (Suunto PM-5/360 PC clinometer) in the transect files. He installed $1.2 \mathrm{~m}$ rebars at the transect ends (one at water's edge and one at the upland end) and at increments of 50 meter or less, as needed, along the length of the transect. In the fall of 2008 , I fitted the transect rebar stakes located at the upland and wetland ends of each transect with a metal rebar cap indicating the transect name and decimeter location. These caps were intended to permanently mark each transect with study information. In 2003, Jenkins re-verified the original compass direction at each point along the transect, correcting any misalignments prior to rebar installation. Because each transect followed a line from the water's edge to a point around $3.4 \mathrm{~m}$ (NGVD 29) elevation and local topography varied, each transect covered a different linear distance. Transects lengths ranged between 21.5 meters and 279.8 meters.

Jenkins (2005) followed the above procedure for 17 of the original transects.

However, for the remaining 13 original transects he modified the transect marking procedure slightly. Because the first season field work continued into the late fall when 
water levels had begun to rise, the low-elevation end of the final 13 transects was established in a location higher in elevation (corresponding to the rising water-level) than the first 17 transects. Generally, this location was on the upland edge of a Salix band surrounding the low-water water's edge. Jenkins (2005) did not make any additional modifications to the transect marking procedures for the final 13 transects.

Due to unforeseen problems, three of the thirty original transects established during the Jenkins (2005) study were not used for analysis in any study year and one transect was used only for vegetation cover analysis in 2004. The total number of transects used in the Jenkins (2005) study for vegetation cover analysis was twenty-seven and the total number of transects used for elevation-based analysis was twenty-six (Jenkins 2005). In this study, the total number of transects used for all analyses was twenty-six.

Of the three transects eliminated from all analyses, one was removed because the upland area was mistakenly mowed during the 2003 field season, making the vegetation data subject to bias. The two other original transects were completely removed from analysis in all study years because vegetation surveys that were conducted in the late fall of 2003 were vastly different than the vegetation surveys from the early fall of 2004 . Because of these differences, Jenkins (2005) performed a field check later in the fall of 2004 and found that the data collected earlier in the 2004 season was not consistent with the vegetation observed later in the 2004 season. He did not perform an additional vegetation survey in the late fall of 2004 for these transects, but rather removed them from analysis. I did not re-survey the vegetation along these transects in the fall of 2008 or 2009 and I did not use data from these transects for any analyses. The transect that 
was used only for vegetation cover analysis in 2004 was not used for other, elevationbased analyses because it was not properly surveyed during the original field studies (Jenkins 2005). I did not survey this transect for vegetation or elevation in 2008 or 2009 and it was not included in any of my analyses.

\section{Transecting Procedure}

I collected vegetation data along the 26 transects following the same procedure as the Jenkins study (2005). Vegetation surveying began in the fall of 2008 and then again in the fall of 2009. In most cases, I visited transects in a stratified random order. I divided the sampling into two groups based on location within the Bybee or Smith portion of the wetland. During both sampling seasons the Bybee portion of SBW drained more quickly due to beaver activity in the channel separating the two areas, resulting in more water retained in Smith Lake compared to Bybee Lake. As a result, emergent vegetation appeared sooner in the Bybee area and some of the lower elevation ends of transects in

the Smith area were completely under water when surveying began. So, surveying began in the Bybee portion of SBW in both the 2008 and 2009 vegetation data collection seasons. Within each sampling group (Bybee or Smith) I selected transects to survey at random each survey date. However, to maximize field efficiency, if I finished collecting data for a transect with survey time remaining in the day, I continued with the next nearest transect.

During vegetation data collection for a transect, occasionally with the help of a field assistant, I strung a 50-meter tape between rebar segments along the transect. I then recorded on project data sheets all living vegetation that intersected a plumb line below or 
a theoretical vertical line above each decimeter point on the 50-meter tape (Elzinga et al. 1998, O’Neill 1999, Sharp 2002, Youngman 2002). Vegetation was recorded to the species level where possible. Plants that were not in a phenological stage to allow species-level identification were identified to the genus level. Plants in the very early cotyledon stage were identified as "unknown" or "unknown seedling."

Upon completion of field vegetation sampling, I entered all vegetation data into an Excel spreadsheet. A "1" was entered for each decimeter where a particular plant species was present. A "0" or blank cell indicated the particular plant species did not appear at a decimeter point. Project staff then entered these electronic files into the overall project database. I scanned original field data sheets into electronic format for project files and future reference.

\section{Surveying Methods}

I collected elevation data along the 26 transects following the same procedure and using the same survey equipment as in the Jenkins study (2005). I followed the methods described in Herubin (1982) for differential leveling and profile leveling using a Topcon AT-G2 auto-level (Precision Instruments, Portland, OR), tripod, and survey rod. I recorded all elevation data in NGVD 29 datum, where necessary converting known benchmark elevations from other reference data (for example, the City of Portland's datum, or Multnomah County's datum) into this datum. I used six permanent benchmarks located within or very near the boundaries of the wildlife area. These benchmarks included four City of Portland benchmarks, one Multnomah County benchmark, and one Metro benchmark (on the Water Control Structure). 
I began elevation leveling with the help of an assistant in September, 2010. We ran level circuits to one or more transects at a time, closing the circuit to the starting benchmark location. Starting benchmarks were either from one of the six permanent benchmarks noted above or from a temporary benchmark established in a level circuit. We established temporary benchmarks in my survey work on or near transects and used these temporary benchmarks to run additional level circuits to transects located further away from permanent benchmarks. All elevation data were recorded to the nearest 0.005 feet $(0.13 \mathrm{~cm})$. I recorded all closure errors and discarded level circuits where the overall error (cumulative error including the error in level circuits that were used to establish a temporary benchmark) was greater than 0.10 feet $(0.25 \mathrm{~cm})$.

To determine elevations along individual transects, I did profile leveling from one or more instrument locations of known elevation near the transect. From these instrument locations, I took rod shots along the transect to establish its topographical profile, usually at 3-meter intervals and at all rebar locations. Where the local slope changed rapidly (i.e. a sharp drop-off) I used smaller distances between rod shots; where the local topography was very uniform (i.e. very little change in elevation) I used longer distances between rod shots.

I initially recorded all elevation data into a field notebook. Following a preliminary quality control check, I entered the elevation data into an Excel file. At this point, project staff used a Visual Basic script in Excel to interpolate the elevations between rod shots along the transect. In so doing, we developed a profile of each transect at decimeter intervals. 
After noticing discrepancies between the elevation data I collected and the data collected during the Jenkins (2005) study, I conferred with the Jenkins team and obtained the correction factors they had used for their elevation data. I then converted all elevation data from 2004 and 2010 to NGVD 1929. Once we accounted for all elevation discrepancies and converted to the NGVD 1929 datum, project staff entered the elevation profiles of each transect into the project database. A complete description of all benchmarks used for the project is found in Appendix C

\section{Water Level Data}

Project staff collected water-level data at a permanent staff gage located on the Bybee wetland side of the water control structure on a weekly basis when possible when one or more stop logs were in place on the structure. However, staff did not take water-level readings when water topped the structure, resuming weekly readings once the water receded to a level where it could be measured on the staff gage. When all stop logs were removed from the structure, staff recorded water-level data from the daily average of hourly readings at the Vancouver Army Corps of Engineers gage (USACE 2010).

During the 2007/2008 water year we used Corps gage readings from October 1, 2007 through November 19, 2007 and again from August 13, 2008 through September 30,2008 . We used manual readings at the water control structure staff gage from November 20, 2007 through August 12, 2008. During the 2008/2009 water year, we used the Corps gage from October 1, 2008 through December 7, 2008 and again from August 18, 2008 through September 30, 2008. We used manual readings at the water control structure staff gage from December 8, 2008 through August 17, 2009. 


\section{Statistical Methods: Abundance Response of Taxa}

I used the baseline vegetation data from 2003, the vegetation data from 2008 and 2009, and the elevation data from 2010 to perform all statistical analyses. When relevant, I used the vegetation data from 2004 to perform additional statistical analyses and make significant comparisons between study years. I examined diversity changes, percent cover changes, and interactions between vegetation and hydrology.

\section{Shannon Diversity Index}

I calculated the Shannon diversity index, $H^{\prime}=-\sum p_{i} \ln \left(p_{i}\right)$, overall, by lake, and on an individual transect level. Shannon diversity does not factor bare ground (points not occupied by any plant species) in the index calculation. For the transect level diversity index calculation, the proportion $\left(\mathrm{p}_{\mathrm{i}}\right)$ for each taxon (i) was calculated based on the number of points on which the plant species was present for a transect divided by the total number of individual plants recorded for that transect. For the overall diversity index calculation, the proportion $\left(\mathrm{p}_{\mathrm{i}}\right)$ for each taxon $(\mathrm{i})$ was calculated based on the total number of points on which the plant species was present for all transects divided by the total number of individual plants recorded for all transects. I eliminated floating aquatic species and bryophytes from the diversity analysis.

I examined the relationship between diversity and the percent cover of the two most abundant species, Phalaris and Polygonum. I used Spearman's rank correlation rho to determine if there was a correlation between cover and diversity. I looked at how diversity changed outside of monotypic stands of Phalaris or Polygonum. For this, I 
calculated the Shannon Diversity Index after removing decimeter locations with only Phalaris or Polygonum present.

\section{Changes in Taxa}

\section{Percent Cover Changes}

I used presence/absence data for vegetation along 26 transects $^{13}$ to determine percent cover of plant species encountered overall, by lake and by transect each year. For the overall and by lake calculations, I totaled the number of points from all the transects on which the plant species was present and divided the total by the total number of points for all transects $(24,088$ decimeters or total number of data collection points on all transects, 9,532 decimeters on transects in Bybee, and 14,556 decimeters on transects in Smith). For the calculations by transect, I divided the number of points along the transect where the plant species was present by the total number of points along the transect. In addition to percent cover for each plant species on each transect, I examined how Phalaris in particular changed in areas that were shaded by Salix in both study years (i.e., Salix were present in a particular location on a transect in both 2003 and 2008 and/or 2009).

\section{Significance of Taxa Changes}

I used the student's paired t-test and McNemar's non-parametric test for significant changes (Zar 1998). The McNemar test is for data that are not independent. The test evaluates whether changes in a positive direction (i.e., absent to present) are significantly different than changes in a negative direction (i.e., present to absent). The test statistic is

\footnotetext{
${ }^{13}$ Jenkins (2005) reported cover changes based on vegetation results from 30 transects.
} 
the McNemar's chi square. I developed contingency matrices using the geodatabase to analyze differences in the overall count of individual plant species between 2003 and 2008 and between 2003 and 2009. The McNemar test compares before (2003) and after (2008 or 2009) for a particular species, with the contingency matrix containing the number of points where the species was present in both years, where it was absent the first year and present the second year, where it was present the first year and absent the second year, and where it was absent both years of study (Table 3).

Table 3: McNemar Contingency Table Structure for a Single Species.

Shown is the McNemar contingency table for a single species used to ascertain if the species was more likely to appear or disappear from a sample location. Each decimeter sample location was assessed for the presence or absence of each species in each year of study. The total decimeter count for each contingency table outcome was determined and used for the McNemar tests. The McNemar chi-squared test is appropriate for paired, before-after data.

\begin{tabular}{|l|l|c|c|}
\hline \multirow{2}{*}{$\begin{array}{l}\text { McNemar Contingency Table for a Single } \\
\text { Species for "Before" and "After" }\end{array}$} & \multicolumn{2}{|c|}{ After } \\
\cline { 2 - 4 } & Species Present (P) & Species Absent (A) \\
\cline { 2 - 4 } Before & Species Present (P) & $\mathrm{P} \rightarrow \mathrm{P}$ & $\mathrm{P} \rightarrow \mathrm{A}$ \\
\cline { 2 - 4 } & Species Absent (A) & $\mathrm{A} \rightarrow \mathrm{P}$ & $\mathrm{A} \rightarrow \mathrm{A}$ \\
\hline
\end{tabular}

When the test yielded a p-value of 0.05 or less, I considered the changes in percent cover to be significant. I tested for significant changes overall, by lake, and between areas that were and were not shaded by Salix. For overall and by lake changes, I simply used the McNemar test. For changes in areas with Salix cover vs. changes in areas without Salix cover, I used heterogeneity testing of the McNemar contingency tables for these two different subsets of the overall data.

\section{Interaction of Phalaris arundinacea with Other Taxa}

To identify if a taxon replaced Phalaris or was replaced by Phalaris at significant levels, I again used the McNemar test. I counted replacement by a species in cases where the species was absent from a certain decimeter on a transect in 2003 but present in 2009 and 
Phalaris was present in 2003 but absent in 2009 from the same decimeter. I counted replacement of the species by Phalaris in cases where the species was present at a certain decimeter on a transect in 2003 but absent in 2009 and Phalaris was absent in 2003 but present in 2009 at the same decimeter. The contingency table for this scenario is shown in Table 4. When the test yielded a p-value of 0.05 or less, I considered the replacement of or replacement by Phalaris to be significant.

Table 4: McNemar Contingency Table Structure for Two Species.

Shown is the McNemar contingency table structure for the interaction between Phalaris and another species. The McNemar test for two species is used to determine if one species is more likely to replace the other species. Each decimeter sample location was assessed for the presence or absence of one or the other species in each year of study. The total decimeter count for each contingency table outcome was determined and used for the McNemar tests. The McNemar chi-squared test is appropriate for paired, before-after data.

\begin{tabular}{|c|c|c|c|}
\hline \multirow{2}{*}{\multicolumn{2}{|c|}{$\begin{array}{l}\text { McNemar Contingency Table for } \\
\text { Replacement of Phalaris by a Species or } \\
\text { Replacement of a Species by Phalaris } \\
\text { using "Before" and "After" }\end{array}$}} & \multicolumn{2}{|c|}{ After } \\
\hline & & Phalaris & Species X \\
\hline \multirow{2}{*}{ Before } & Phalaris & Phalaris $\rightarrow$ Phalaris & Phalaris $\rightarrow$ Species $\mathrm{X}$ \\
\hline & Species X & Species $\mathrm{X} \rightarrow$ Phalaris & Species $X \rightarrow$ Species $X$ \\
\hline
\end{tabular}

\section{Determination of Depth and Duration of Flooding}

I examined hydrology data by water year, which spans from October 1 to September 30.

I determined the maximum water elevation (NGVD 1929) for the 2007/2008 water year and for the 2008/2009 water year based on the maximum recorded value at the water control structure staff gage. From this, I determined the maximum water depth (inundation) experienced throughout the range of transect elevations (1.71 meters NGVD 1929 to 4.19 meters NGVD, based on elevations surveyed in the fall of 2010). For each transect, I recorded the maximum inundation experienced at each decimeter by 
subtracting the interpolated transect elevations from the maximum water elevation for both the $2007 / 2008$ water year and for the $2008 / 2009$ water year.

To determine the duration of inundation, I counted the number of days that water levels were at certain elevations, in 0.10 meter intervals (e.g., the number of days that the water elevation was between 0.80 meters and 0.90 meters). I then found the number of days that water elevation was above a certain elevations (i.e. the total number of days that water elevation was above 0.80 meters, above 0.70 meters, and so on). Finally, I recorded the total number of days that water elevation was above the elevation of the interpolated transect elevations (i.e. the number of days that a point on a given transect was under water based on its interpolated land elevation).

I determined if there was a clear and consistent relationship between maximum inundation and total duration of flooding. If so, I would be justified in using one or the other of these two factors in analysis. To determine the relationship between the maximum inundation and the total duration of flooding, I used the natural log of maximum inundation and the natural log of duration to find Spearman's rho (correlation test) and its significance (p-value).

The above methodology was accurate only for transects in the Bybee portion of the wetland due to the presence of a beaver dam in the channel connecting Bybee and Smith. We surveyed the beaver dam during the fall of 2009 and determined its elevation to be 2.29 meters (NGVD 1929). During this survey, we also determined the elevation of the water on the Smith side of the dam to be 2.21 meters (NGVD 1929). Once water in Bybee was below the elevation of the dam (on August 1 in 2009), the water levels and draw-down rate in Smith and in Bybee were no longer the same. Bybee continued to 
drain to the level of the lowest stop log and, ultimately, the level of the North Slough. Water elevation in Smith also dropped, however, only at the rate of evapotranspiration minus accumulation made by rainfall (assuming groundwater flux was not a factor). The correlation between maximum inundation and duration of inundation before and after the water elevation of the beaver dam was reached would no longer be linear for the Smith portion of the wildlife area.

\section{Impact of Flooding and Salix on Phalaris arundinacea Response}

I used multinomial logistic regression in R to determine the combined effects of Salix cover and flooding on Phalaris response. The predictor variables in the regression were maximum inundation and Salix cover. I considered Salix to be present in decimeter locations on transects where it was present both years (present in 2003 and in 2009). For the regression analysis, Salix present was indicated with a "1." Salix was counted as absent in decimeter locations on transects where Salix was absent both years or where it was present one year but not the other. I used four categories of change in Phalaris cover by decimeter as the response variable and the maximum inundation and presence or absence of Salix by decimeter as the predictor variables. The four categories of Phalaris cover were 1) when Phalaris was present in 2003 but absent in 2009 ("1", the reference case), 2) when Phalaris was absent both years ("2"), 3) when Phalaris was absent in 2003 but present in 2009 (“3”), and 4) when Phalaris was present in both years (“4”). I determined the Phalaris change by directly comparing the 2003 vegetation data to the 2009 vegetation data at each decimeter. The reference case has a value of 1 . Results are 
presented as odds ratios with values greater than 1 indicating the case is more likely to occur and values less than 1 indicating the case is less likely to occur.

\section{Interaction of Phalaris arundinacea and Polygonum with Inundation}

I used multinomial logistic regression in $\mathrm{R}$ to analyze the relationship between hydrology and the interaction between Phalaris and Polygonum. I used the maximum inundation to serve as the predictor variable in the regression and the interaction between Phalaris and Polygonum was the response variable. The sixteen categories of the PhalarisPolygonum response are shown in Table 5. I determined the Phalaris and the Polygonum changes by directly comparing the 2003 vegetation data to the 2009 vegetation data at each decimeter. 
Table 5: Phalaris - Polygonum Response Categories.

Shown are the categories of response for the Phalaris- Polygonum interaction. The categories were used for the multinomial logistic regression analysis of the relationship between hydrology and the interaction between Phalaris and Polygonum.

\begin{tabular}{|l|l|l|l|}
\hline Case & Phalaris Response & Polygonum Response & Category Description \\
\hline 1 & Present $\rightarrow$ Absent & Absent $\rightarrow$ Present & Polygonum replaces Phalaris \\
\hline 2 & Absent $\rightarrow$ Present & Present $\rightarrow$ Absent & Phalaris replaces Polygonum \\
\hline 3 & Absent $\rightarrow$ Absent & Absent $\rightarrow$ Present & $\begin{array}{l}\text { Phalaris remains absent, Polygonum } \\
\text { appears }\end{array}$ \\
\hline 4 & Present $\rightarrow$ Present & Absent $\rightarrow$ Present & $\begin{array}{l}\text { Phalaris remains present, Polygonum } \\
\text { appears }\end{array}$ \\
\hline 5 & Present $\rightarrow$ Absent & Present $\rightarrow$ Present & $\begin{array}{l}\text { Phalaris disappears, Polygonum remains } \\
\text { present }\end{array}$ \\
\hline 6 & Present $\rightarrow$ Present & Present $\rightarrow$ Absent & $\begin{array}{l}\text { Phalaris remains present, Polygonum } \\
\text { disappears }\end{array}$ \\
\hline 7 & Absent $\rightarrow$ Present & Present $\rightarrow$ Present & $\begin{array}{l}\text { Phalaris appears, Polygonum remains } \\
\text { present }\end{array}$ \\
\hline 8 & Absent $\rightarrow$ Present & Absent $\rightarrow$ Present & Both species appear \\
\hline 9 & Present $\rightarrow$ Absent & Present $\rightarrow$ Absent & Both species disappear \\
\hline 10 & Absent $\rightarrow$ Present & Absent $\rightarrow$ Absent & $\begin{array}{l}\text { Phalaris appears, Polygonum remains } \\
\text { absent }\end{array}$ \\
\hline 11 & Absent $\rightarrow$ Absent & Absent $\rightarrow$ Absent & Both species remain absent \\
\hline 12 & Present $\rightarrow$ Absent & Absent $\rightarrow$ Absent & $\begin{array}{l}\text { Phalaris disappears, Polygonum remains } \\
\text { absent }\end{array}$ \\
\hline 13 & Absent $\rightarrow$ Absent & Present $\rightarrow$ Absent & $\begin{array}{l}\text { Phalaris remains absent, Polygonum } \\
\text { disappears }\end{array}$ \\
\hline 14 & Absent $\rightarrow$ Absent & Present $\rightarrow$ Present & $\begin{array}{l}\text { Phalaris remains absent, Polygonum } \\
\text { remains present }\end{array}$ \\
\hline 15 & Present $\rightarrow$ Present & Absent $\rightarrow$ Absent & $\begin{array}{l}\text { Phalaris remains present, Polygonum } \\
\text { remains absent }\end{array}$ \\
\hline 16 & Present $\rightarrow$ Present & Present $\rightarrow$ Present & Both species remain present \\
\hline & & & \\
\hline
\end{tabular}




\section{Cover Changes by Elevation/Maximum Inundation/Duration of Inundation}

I divided vegetation data from 26 transects $^{14}$ into segments based on maximum inundation to determine if cover changes were different under different hydrological regimes. I tallied all species counts within 0.10-meter increments of maximum inundation. I presented the results graphically to assess if there were apparent differences in response under different hydrological conditions. Where differences were clearly present, I used heterogeneity testing of the McNemar contingency tables for the species count below and above the apparent maximum inundation break point.

Based on the above assessment, for Phalaris, I tested the populations above and below 2.5 meters and 3.1 meters. For Polygonum, I tested the population above and below 2.0 meters. For Salix, I tested the population above and below 2.1 meters. For Bidens, I tested the population above and below 2.5 meters. For Carex, I tested the population above and below 3.6 meters. For Ludwigia, I tested the population above and below 2.4 meters. I also tested the differences in vegetation response based on elevation between the lakes. By-lake differences are reported in Appendix B.

\footnotetext{
${ }^{14}$ Jenkins (2005) reported vegetation changes by maximum inundation based on vegetation data from 27 transects.
} 


\section{Chapter 3: Results}

\section{Depth vs. Duration}

Since initiation of water management at SBW in the fall of 2003, average water levels in SBW have generally been higher in the winter and spring months and lower in summer and early fall months than in the years preceding water management (Figure 5).

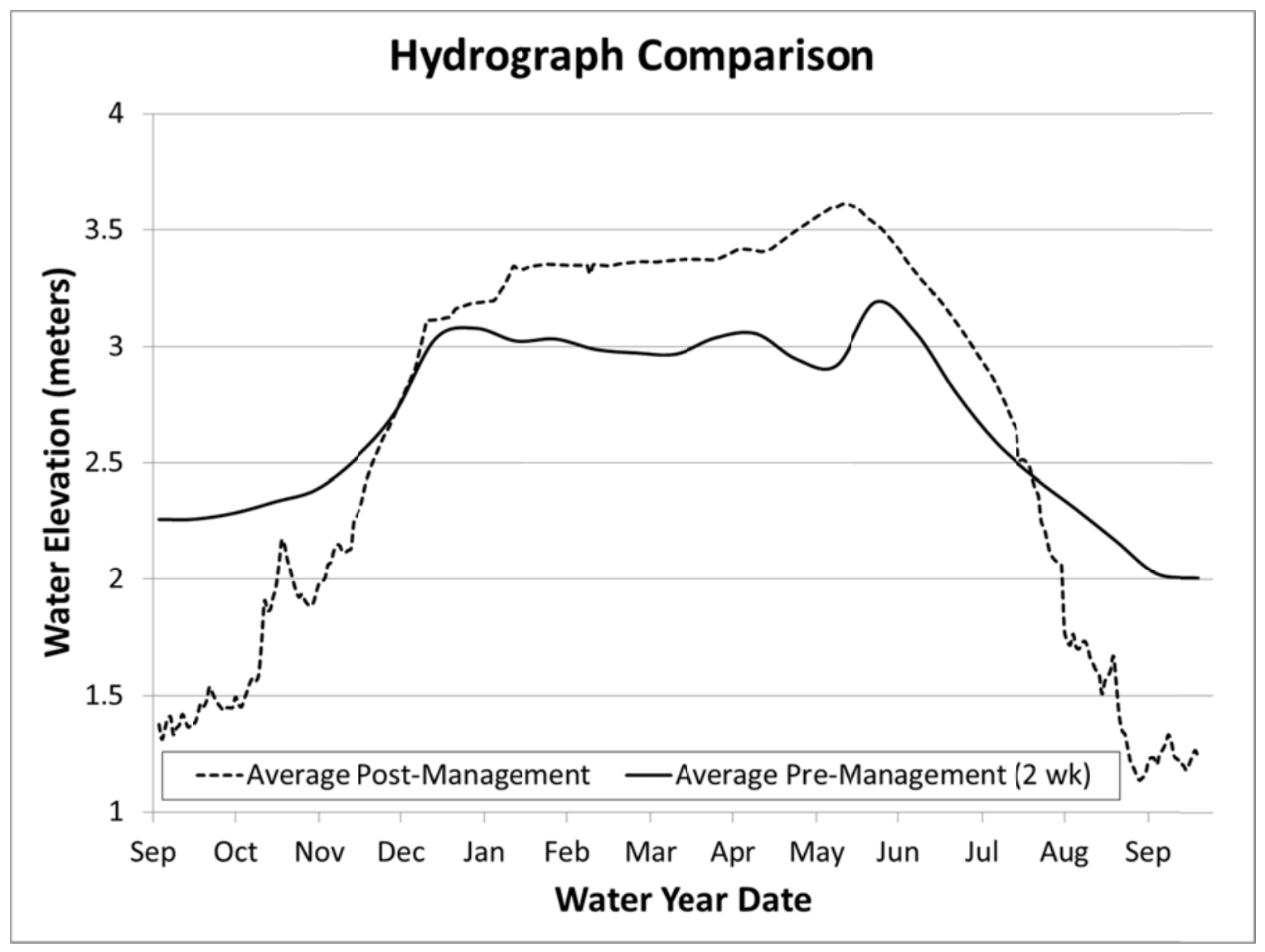

Figure 5: Average Pre- and Post-Water Management Hydrographs.

Pre-management average hydrology uses hydrology data from the fall of 1996 through the fall of 2003 (before installation of WCS). Due to missing data for pre-water management hydrology, the 2-week average was averaged. Post management average hydrology uses hydrology data from the fall of 2003 (after installation of the WCS) through the fall of 2009. 
This trend held for each water year following WCS installation (Figure 6) with the exception of the 2004/2005 and the 2006/2007 water years where winter levels did not exceed 4 meters (NGVD29). Figure 6 also shows the daily tidal fluctuations that SBW experienced once all the WCS stop logs were removed in the summer and the Wetlands had a free and open connection to the North Slough/Columbia River system. 


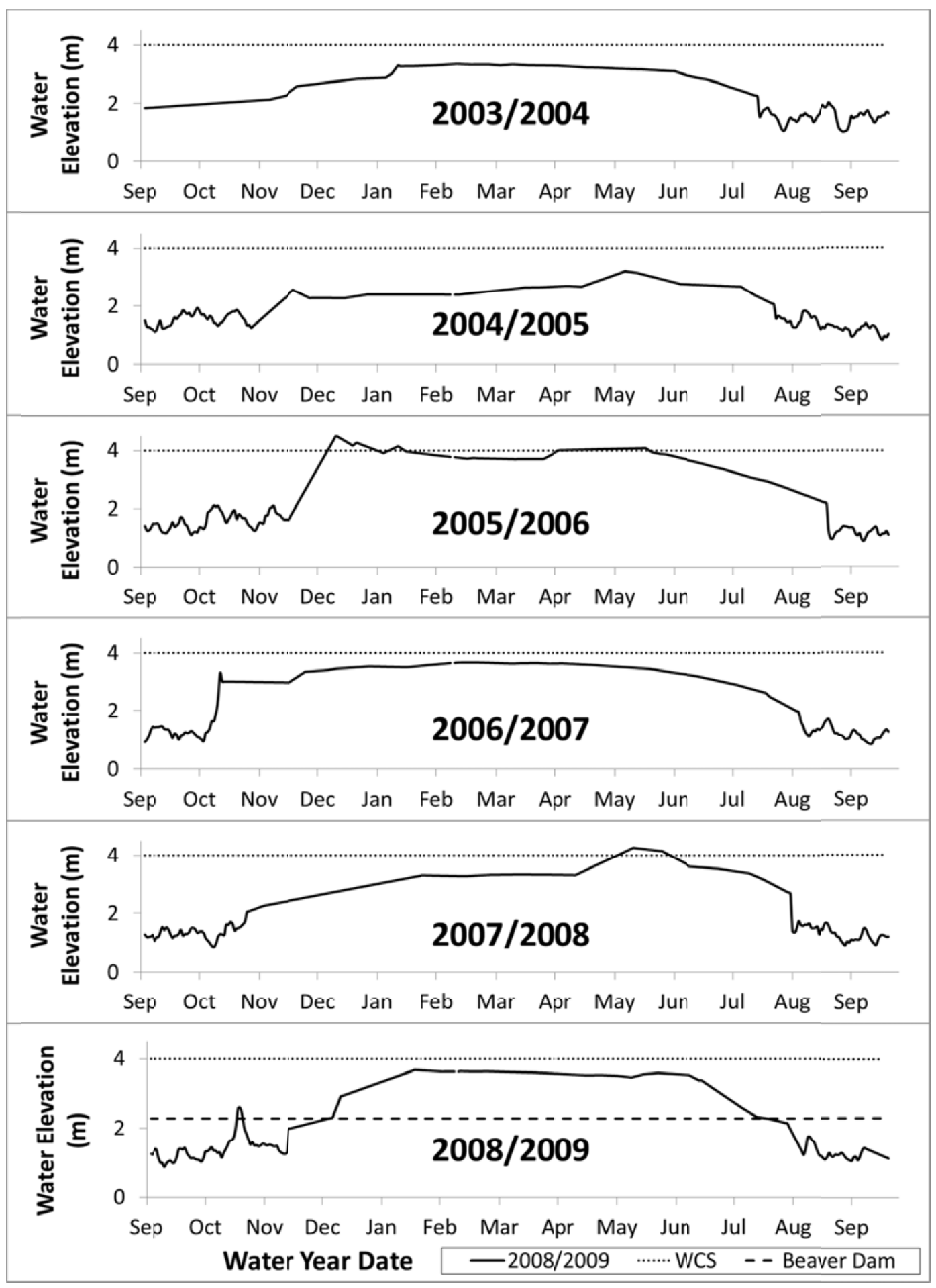

Figure 6: Managed Flooding Hydrographs.

This figure depicts hydrographs for each water year following Water Control Structure (WCS) installation. The 2008/2009 hydrograph includes the elevation of the beaver dam as 2.29 meters, surveyed in November of 2009. The elevation of the WCS is approximately 4 meters. 
The water years immediately before vegetation data collection were assumed to be the most critical to their respective datasets. For the 2008 vegetation data set, the 2007-2008 water year (extending from 10/1/2007 through 9/30/2008) was most important and for the 2009 vegetation data set, the 2008-2009 water year (extending from 10/1/2008 through 9/30/2009, Figure 7) was most important. The cumulative effects of water management since the WCS was installed were also important, but since the project team did not collect vegetation data for 2005,2006 , or 2007 , it was difficult to discern the exact relationship.

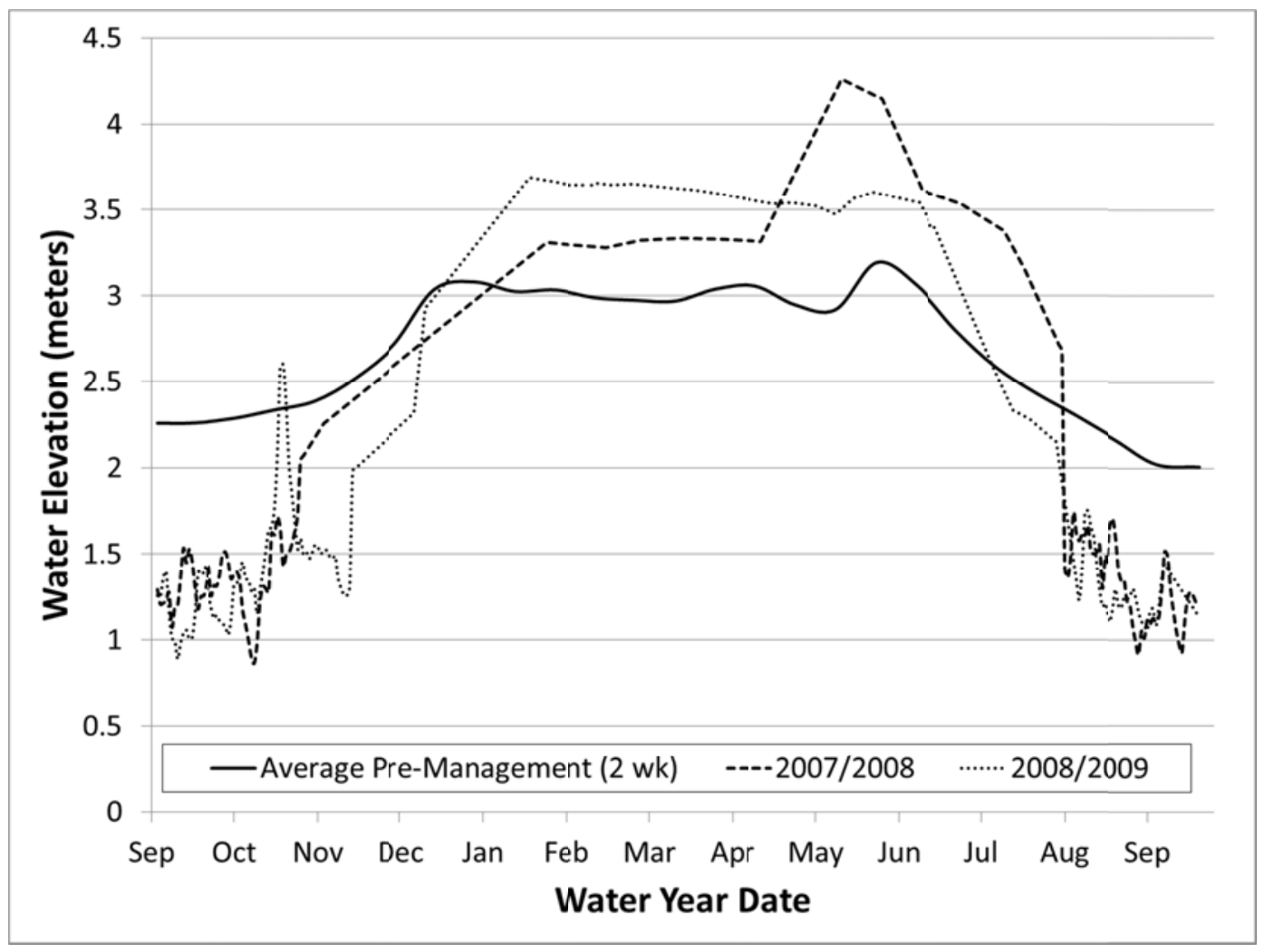

Figure 7: Important Hydrographs for This Study.

This figure shows the hydrographs of the average pre-WCS hydrology compared to the 2007-2008 water year and the 2008-2009 water year. These three hydrographs are considered the most important for this study. 
Maximum inundation was correlated with the duration of inundation and the relationship was linear (correlation test $p$-value $<0.001$ for 2009). For this reason, throughout the analyses I only utilized maximum inundation. However, as mentioned in the Methods section, the correlation was only valid for Bybee Lake and the portion of Smith Lake above the $2.29 \mathrm{~m}$ (natural $\log =0.83$ ) elevation. The beaver dam impounded Smith Lake below that elevation. It was unclear what the actual relationship of Maximum Inundation to Duration of Inundation was in Smith Lake once water levels dropped below the beaver dam.

\section{Duration and Timing of Flooding}

The maximum water elevation during the 2007-2008 water year was 4.26 meters (NGVD 1929) recorded on May 27, 2008. The maximum water elevation during the 2008-2009 water year was 3.69 meters, recorded from the staff gage on February 8, 2009. Although the maximum water elevation in 2007/2008 was higher due to a high water event in May and June of 2008, the period of time during which water elevations were above 3.45 meters was longer during the 2008/2009 season. Table 6 shows the maximum water depths (inundation) achieved at a range of ground elevations. The highest elevation on any of the transects is 4.19 meters (NGVD 1929), the lowest is 1.71 meters. 
Table 6: Transect Hydrology for 2007/2008 and 2008/2009 Water Years.

Shown are the maximum water depth (inundation) and duration of inundation for the range of transect elevations. " 0 " values indicate that water did not reach the transect elevation. Duration days represent the number of days water was present at the corresponding transect elevation.

\begin{tabular}{|c|c|c|c|c|}
\hline $\begin{array}{l}\text { Transect } \\
\text { Elevation } \\
\text { (meters }\end{array}$ & $\begin{array}{l}\text { Maximum } \\
\text { Inundation } \\
2008 \text { (meters) }\end{array}$ & $\begin{array}{l}\text { Duration } 2008 \\
\text { (days) }\end{array}$ & $\begin{array}{l}\text { Maximum } \\
\text { Inundation } 2009 \\
\text { (meters) }\end{array}$ & $\begin{array}{l}\text { Duration } 2009 \\
\text { (days) }\end{array}$ \\
\hline 1.7 & 2.56 & 271 & 1.99 & 258 \\
\hline 1.8 & 2.46 & 267 & 1.89 & 255 \\
\hline 1.9 & 2.36 & 267 & 1.79 & 253 \\
\hline 2 & 2.26 & 267 & 1.69 & 250 \\
\hline 2.1 & 2.16 & 264 & 1.59 & 241 \\
\hline 2.2 & 2.06 & 261 & 1.49 & 230 \\
\hline 2.3 & 1.96 & 255 & 1.39 & 216 \\
\hline 2.4 & 1.86 & 248 & 1.29 & 208 \\
\hline 2.5 & 1.76 & 240 & 1.19 & 204 \\
\hline 2.6 & 1.66 & 233 & 1.09 & 200 \\
\hline 2.7 & 1.56 & 225 & 0.99 & 196 \\
\hline 2.8 & 1.46 & 214 & 0.89 & 192 \\
\hline 2.9 & 1.36 & 204 & 0.79 & 190 \\
\hline 3 & 1.26 & 194 & 0.69 & 183 \\
\hline 3.1 & 1.16 & 184 & 0.59 & 176 \\
\hline 3.2 & 1.06 & 174 & 0.49 & 169 \\
\hline 3.3 & 0.96 & 142 & 0.39 & 162 \\
\hline 3.4 & 0.86 & 80 & 0.29 & 153 \\
\hline 3.5 & 0.76 & 68 & 0.19 & 140 \\
\hline 3.6 & 0.66 & 50 & 0.09 & 68 \\
\hline 3.7 & 0.56 & 42 & 0 & 0 \\
\hline 3.8 & 0.46 & 37 & 0 & 0 \\
\hline 3.9 & 0.36 & 31 & 0 & 0 \\
\hline 4 & 0.26 & 25 & 0 & 0 \\
\hline 4.1 & 0.16 & 20 & 0 & 0 \\
\hline 4.2 & 0.06 & 9 & 0 & 0 \\
\hline
\end{tabular}




\section{Phalaris arundinacea Response to Water Management}

The major results of this study relating to Phalaris were a greatly reduced overall cover and a refinement of the Jenkins et al. (2008) ideal depth for Phalaris control based on year 5 and year 6 vegetation data. Overall Phalaris cover declined by over one-third between 2003 and 2008/2009. Cover change results are discussed in greater detail in the Percent cover section below.

In this study, Phalaris cover was reduced in areas that experienced at least 0.6 meters of maximum inundation (Figure 8). In areas with greater than 1.2 meters of maximum inundation, Phalaris cover began to drop off exponentially to the point where it was almost completely eliminated. In areas with less than 0.6 meters of maximum inundation there was a slight, but significant, increase in Phalaris cover.

Figure 8 shows both the distribution of Phalaris in 2003 and the change in Phalaris corresponding to the maximum inundation in 2008 (Figure 8 a) and 2009 (Figure $8 \mathrm{~b}$ ). The grey bars in Figure 8 show the distribution of Phalaris in 2003, prior to water management, within 0.10 meter elevation-based increments. The black bars in Figure 8 show the change in Phalaris cover from 2003 to 2008 or 2009 (2008 or 2009 count minus 2003 count) within each increment. Maximum inundation is the elevationbased increment used in the figure, but it is interchangeable with transect elevation (refer to Table 6). 


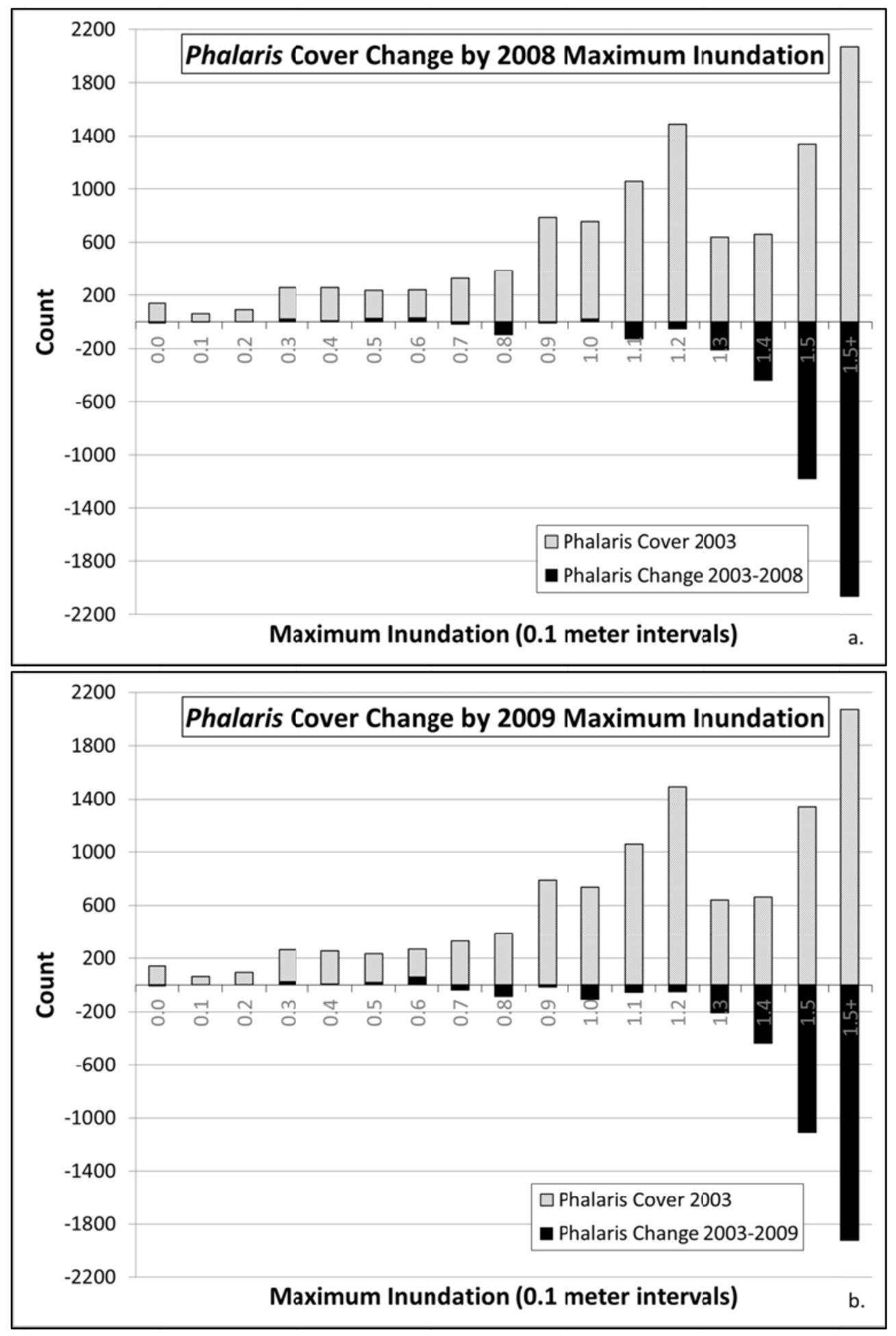

Figure 8 a.-b.: Phalaris Cover and Change by Maximum Inundation.

The count for 2003 cover and change from 2003 to 2009 are divided into maximum inundation intervals based on 2009 hydrology. Maximum inundation is in 0.1 meter intervals, with the deeper end of the inundation interval shown (e.g. ' $0.7 \mathrm{~m}$ ' is the interval from $0.6 \mathrm{~m}$ to $0.7 \mathrm{~m}$ of maximum inundation). 


\section{Diversity}

The Shannon Diversity Index varied by year, by lake (Smith or Bybee), and by

population (Table 7). As outlined in the Methods, Shannon Diversity Index section, the

Shannon Diversity Index calculation did not include floating aquatic species or

bryophytes.

Table 7: Shannon Diversity Index values.

Diversity was calculated for the entire sampled population and for the population outside of monocultures of Phalaris or Polygonum. Index values were calculated for the entire study area represented by 26 transects totaling approximately $2.4 \mathrm{~km}$ and for each of the Smith (13 transects, approximately $1.4 \mathrm{~km})$ and Bybee (13 transects, approximately $1.1 \mathrm{~km}$ ) portions of the study area.

\begin{tabular}{|c|c|c|c|c|}
\hline & $\begin{array}{l}\text { Shannon } \\
\text { Diversity Index, } \\
2003\end{array}$ & $\begin{array}{l}\text { Shannon } \\
\text { Diversity Index, } \\
2004\end{array}$ & $\begin{array}{l}\text { Shannon } \\
\text { Diversity Index, } \\
2008\end{array}$ & $\begin{array}{l}\text { Shannon } \\
\text { Diversity Index, } \\
2009\end{array}$ \\
\hline \multicolumn{5}{|l|}{ Entire Population } \\
\hline Full Study Area & 2.53 & 2.60 & 2.51 & $2.40^{*}$ \\
\hline Smith Subset & 2.55 & 2.59 & 2.47 & $2.28 * *$ \\
\hline Bybee Subset & 2.34 & $2.49^{*}$ & 2.42 & 2.37 \\
\hline \multicolumn{5}{|c|}{ Population Outside of Monocultures (of Phalaris or Polygonum) } \\
\hline Full Study Area & 2.85 & 2.77 & $2.73 *$ & $2.70 * *$ \\
\hline Smith Subset & 2.79 & 2.68 & $2.65^{*}$ & $2.54 * *$ \\
\hline Bybee Subset & 2.78 & 2.74 & 2.68 & $2.62 *$ \\
\hline
\end{tabular}

* - Significantly different from the 2003 Shannon Diversity Index, p-value less than 0.05

** - Significantly different from the 2003 Shannon Diversity Index, p-value less than 0.01

Overall, diversity decreased for the entire population and the population outside of monocultures of Phalaris or Polygonum. The diversity decrease was significant between 2003 and 2009 for the entire population in the full study area and the Smith subset. It was also significant between 2003 and 2008 for the population outside of monocultures in the full study area and the Smith subset and between 2003 and 2009 for the population outside of monocultures in the full study area and both subsets. Diversity in Bybee between 2003 and 2008 and 2009 was not significantly different. The only significant increase in diversity was in Bybee Lake between 2003 and 2004. 
Additionally, the relationship between Shannon diversity $\left(\mathrm{H}^{\prime}\right)$ and Phalaris cover has changed since initiation of managed flooding at SBW (Figure 9).

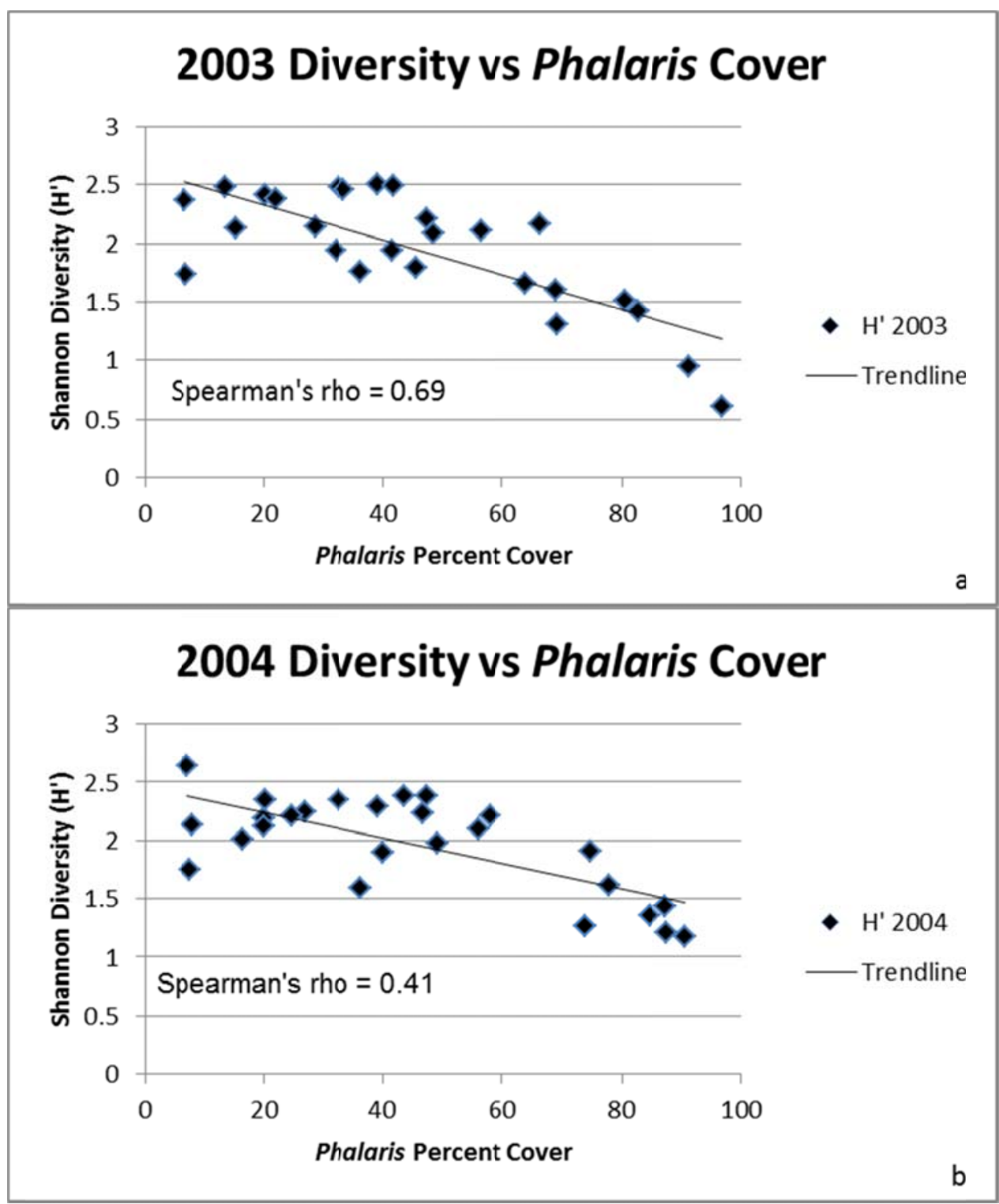




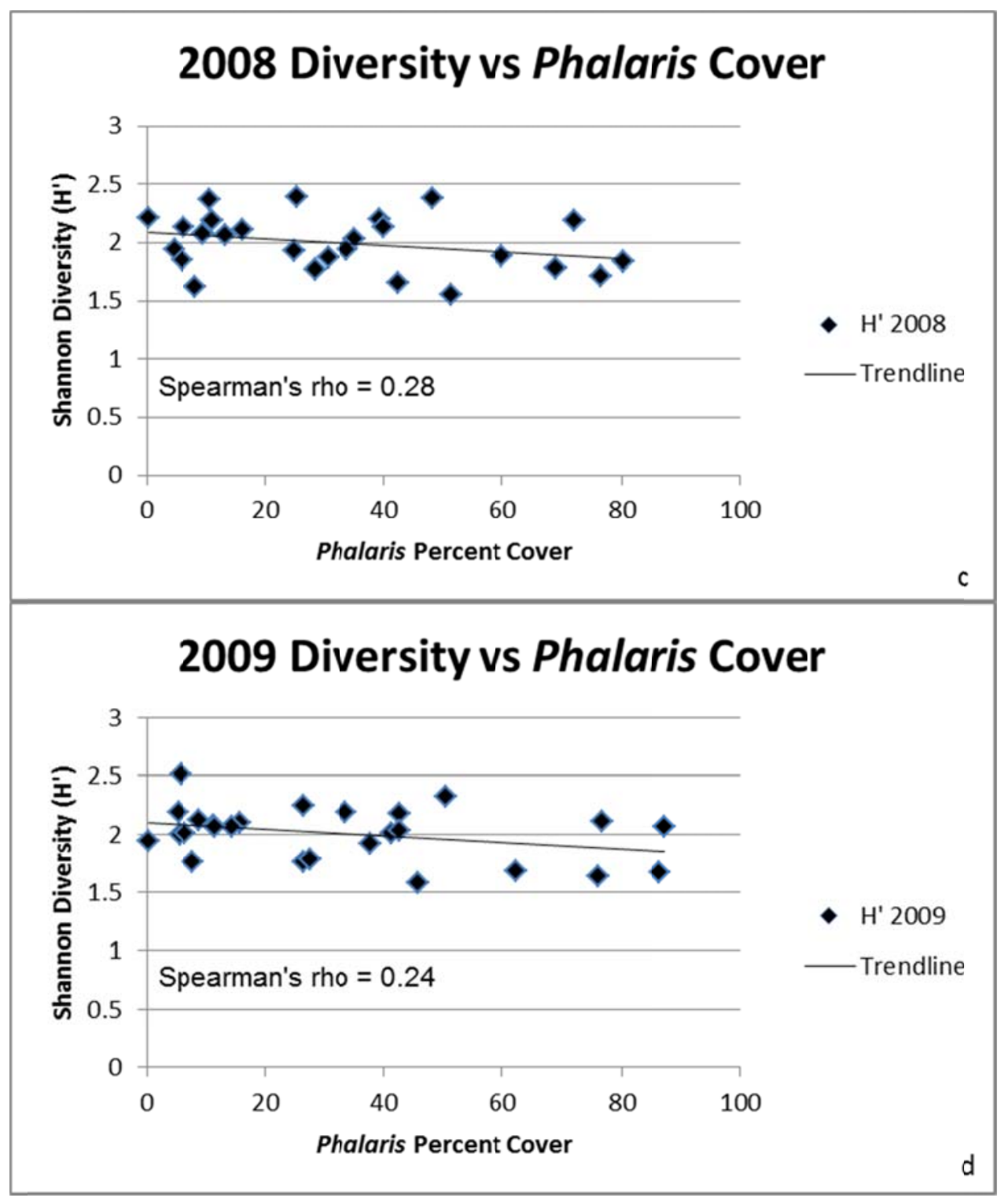

Figure 9 a.-d.: Diversity vs. Phalaris Cover.

Shown is the Shannon diversity index value versus Phalaris cover for (a) 2003, (b) 2004, (c) 2008, and (d) 2009. Points on the graph represent the percent cover of Phalaris and the Shannon diversity of each of the 26 transects.

In 2003, the presence of Phalaris stands had a significant negative correlation with species diversity. Percent cover of Phalaris and Shannon diversity index in 2003 were correlated (Spearman's rho $=0.69, \mathrm{p}$-value $<0.001)$. The year after water management began (2004), Phalaris percent cover and Shannon diversity were also 
correlated (Spearman's rho $=0.41, \mathrm{p}$-value $<0.05)$. However, this negative correlation disappeared in 2008 and 2009 (Spearman's rho $2008=0.28$, p-value $>0.05$ and Spearman's rho $2009=0.24, \mathrm{p}$-value $>0.05)$. This general trend was observed in the Bybee subset in 2003 (Spearman's rho $2003=0.82$, p-value $<0.001$ ) but not 2008 (Spearman's rho $2008=0.41$, p-value $>0.05$ ) or in 2009 (Spearman's rho $2009=-0.15$, $\mathrm{p}$-value $>0.05)$. In the Smith subset, there was never a negative correlation between diversity and Phalaris cover (Spearman's rho $2003=0.38$, p-value $>0.05$; Spearman's rho $2008=0.23$, p-value $>0.05$; and Spearman's rho $2009=0.47$, p-value $>0.05$ ).

In contrast, vegetation data analyses in 2003 and 2004 showed no relationship between diversity and Polygonum cover (Spearman's rho $2003=0.089$, p-value $>0.05$ and Spearman's rho $2004=0.18$, p-value $>0.05)$. However, in 2008 and 2009 Polygonum were negatively correlated with Shannon diversity (Spearman's rho $2008=$ 0.37, p-value $<0.05$ and Spearman's rho $2009=0.38$, p-value $<0.05$ ) (Figure 10). This trend was observed in the Smith subset, but not in the Bybee subset. 


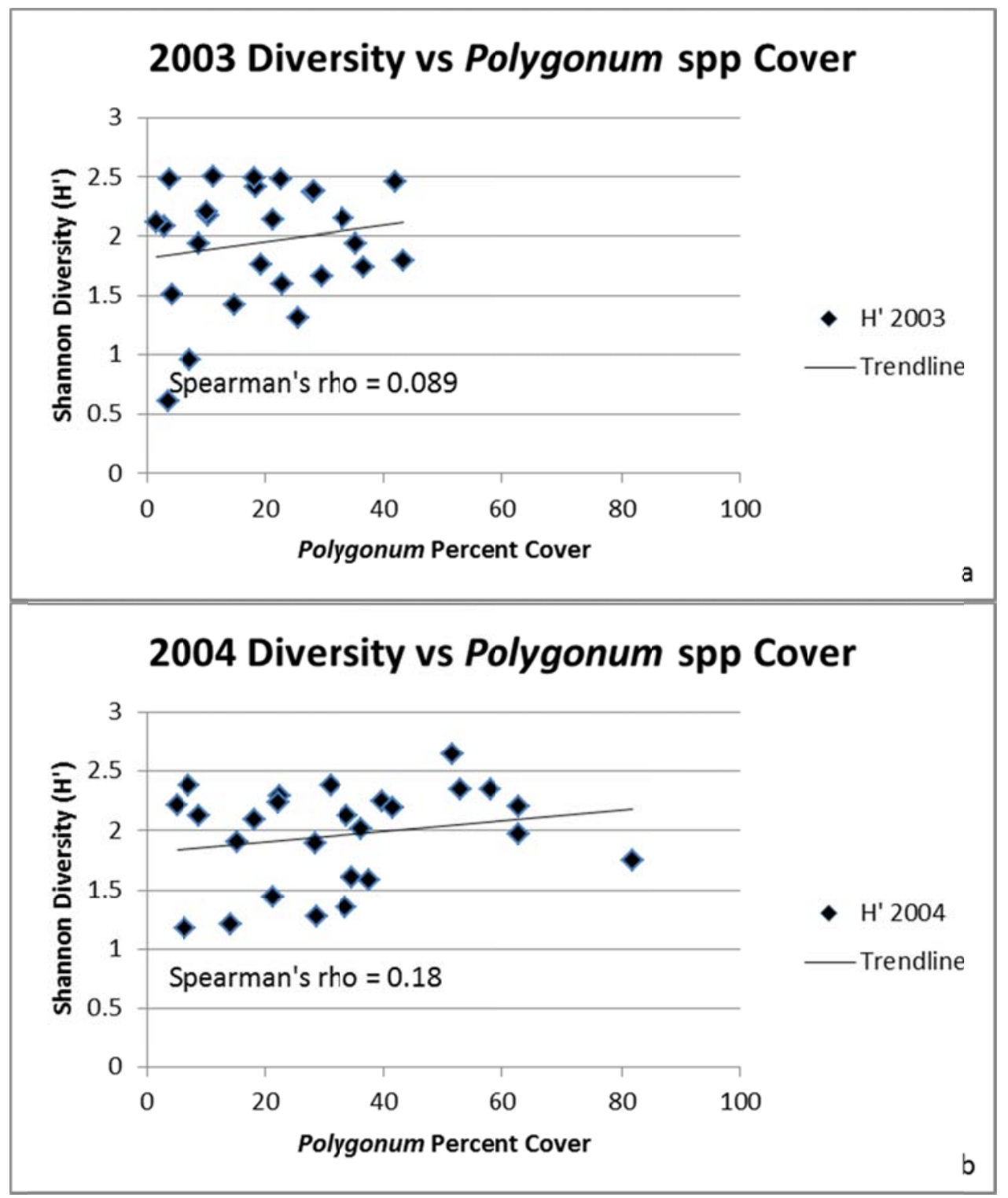




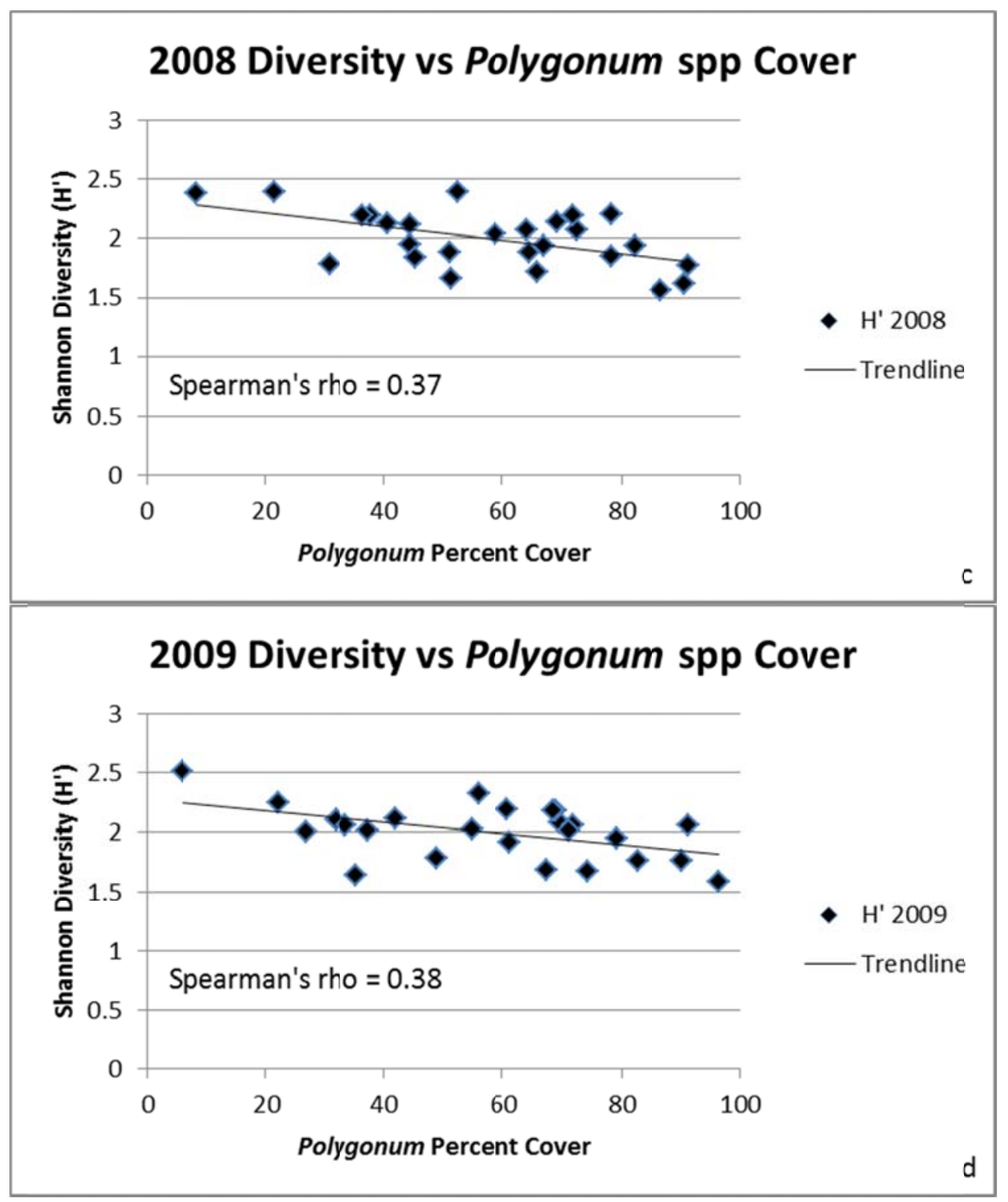

Figure 10 a.-d.: Diversity vs. Polygonum Cover.

Shannon diversity versus Polygonum species cover for (a) 2003, (b) 2004, (c) 2008, and (d) 2009. Points on the graph represent the percent cover of Polygonum species and the Shannon diversity of each of the 26 transects.

After I examined the overall relationship between diversity and cover of Phalaris and Polygonum (Figure 9 and Figure 10), I looked at the relationship between diversity and cover of Phalaris and Polygonum below $80 \%$ cover. The relationship appeared different above and below $80 \%$ cover, and samples with greater than $80 \%$ seemed to the 
main factor related to the negative correlation because they were considerably lower than the samples below $80 \%$ cover. I found that the significant negative relationship between Phalaris cover and diversity was still there (though less strong) in 2003 (p-value 0.027) after I removed transects with Phalaris cover greater than $80 \%$ from the correlation test. The relationship was not significantly correlated for transects with less than $80 \%$ cover in $2004(p$-value $=0.108)$. There was never a negative relationship between diversity and cover of Phalaris in 2008 or 2009.

For Polygonum, after I removed transects with greater than $80 \%$ cover of Polygonum from the correlation test, there was no relationship between diversity and Polygonum cover in 2008 or 2009 (p-value $=0.232$ and 0.096, respectively). There was never a negative relationship between diversity and cover of Polygonum cover in 2003 or 2004, nor were there enough transects with Polygonum cover above $80 \%$ to run a correlation test in these study years.

\section{Percent cover}

Based on analysis of vegetation data from 26 transects, Phalaris was the most abundant species in 2003 (44.4 percent cover), prior to initiation of water management at SBW. It was also the most abundant species in 2004 (42.3 percent cover). In 2008 and 2009, the most abundant species had shifted to Polygonum (53.6 and 52.6 percent cover, respectively). Other species with greater than 5 percent cover in at least one of the study years include Ludwigia palustris, Bidens, Salix, Cyperus strigosus L., and Veronica. Of these major species, only Salix increased in cover. Veronica showed mixed results; in 2004 and 2009 it increased in cover, while in 2008 it decreased in cover. Ludwigia, 
Bidens, and Cyperus strigosus all decreased in cover overall. Areas where there was no vegetation, including bare ground and standing water, represented a significant amount of transect areas, especially during the 2008 and 2009 study years and in the Smith portion of the study area. Table 8 details the species with greater than 5 percent cover by study year as well as the percent of transects that was unvegetated. Figure 11 shows the response of major species and bare ground. There were differences in response between Smith Lake and Bybee Lake (Appendix B).

Table 8: Major Cover Changes.

This table shows the percent cover of major species (greater than 5 percent cover in at least one study year) and bare ground for each of the years for which vegetation data are available. All changes in percent cover are significant (McNemar's chi-squared, p-value $<0.05$ ).

\begin{tabular}{|c|c|c|c|c|c|c|c|}
\hline Species & $\begin{array}{l}2003 \\
\text { Percent } \\
\text { Cover }\end{array}$ & $\begin{array}{l}2004 \\
\text { Percent } \\
\text { Cover }\end{array}$ & $\begin{array}{l}2008 \\
\text { Percent } \\
\text { Cover }\end{array}$ & $\begin{array}{l}2009 \\
\text { Percent } \\
\text { Cover }\end{array}$ & $\begin{array}{l}\text { Percent } \\
\text { Cover } \\
\text { Change, } \\
\text { 2003-2004 }\end{array}$ & $\begin{array}{l}\text { Percent } \\
\text { Cover } \\
\text { Change, } \\
\text { 2003-2008 }\end{array}$ & $\begin{array}{l}\text { Percent } \\
\text { Cover } \\
\text { Change, } \\
\text { 2003-2009 }\end{array}$ \\
\hline $\begin{array}{l}\text { Phalaris } \\
\text { arundinacea }\end{array}$ & 44.36 & 42.34 & 27.47 & 28.09 & -2.02 & -16.89 & -16.27 \\
\hline $\begin{array}{l}\text { Ludwigia } \\
\text { palustris }\end{array}$ & 22.23 & 20.88 & 15.97 & 20.12 & -1.35 & -6.26 & -2.11 \\
\hline $\begin{array}{l}\text { Polygonum } \\
\text { species }\end{array}$ & 19.95 & 33.24 & 53.59 & 52.58 & 13.29 & 33.64 & 32.63 \\
\hline $\begin{array}{l}\text { Bidens } \\
\text { species }\end{array}$ & 11.98 & 15.38 & 7.30 & 5.84 & 3.40 & -4.68 & -6.14 \\
\hline $\begin{array}{l}\text { Salix } \\
\text { species }\end{array}$ & 10.90 & 14.85 & 18.57 & 15.52 & 3.95 & 7.67 & 4.62 \\
\hline $\begin{array}{l}\text { Cyperus } \\
\text { strigosus }\end{array}$ & 5.69 & 7.03 & 0.54 & 1.36 & 1.34 & -5.15 & -4.33 \\
\hline $\begin{array}{l}\text { Veronica } \\
\text { species }\end{array}$ & 3.01 & 8.52 & 2.18 & 5.65 & 5.51 & -0.83 & 2.64 \\
\hline $\begin{array}{l}\text { Bare } \\
\text { Ground }^{15}\end{array}$ & 3.86 & 6.02 & 12.47 & 17.03 & 2.16 & 8.61 & 13.17 \\
\hline
\end{tabular}

\footnotetext{
${ }^{15}$ Bare ground includes both unvegetated soil surface and standing water with no rooted vegetation on the underlying substrate.
} 


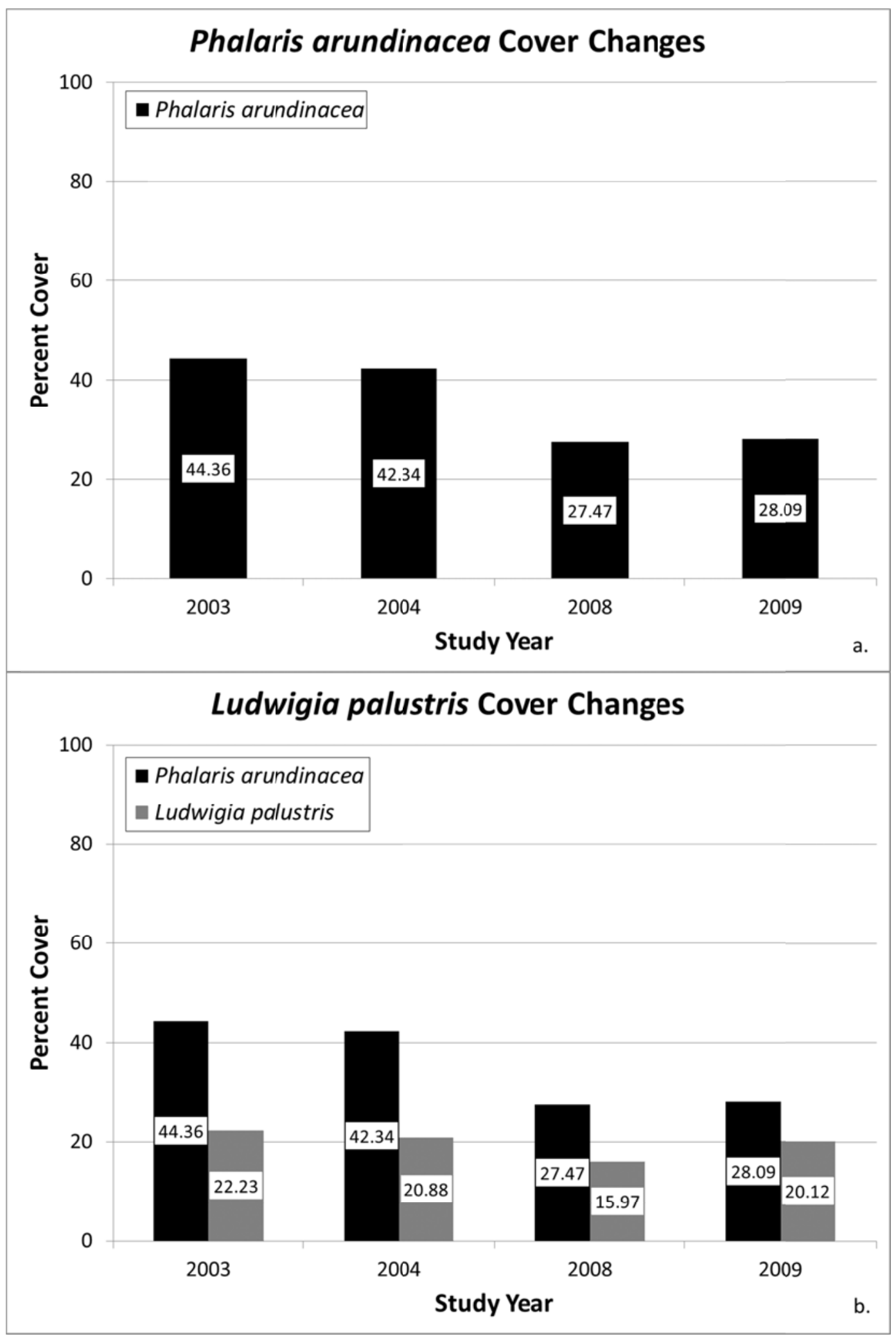




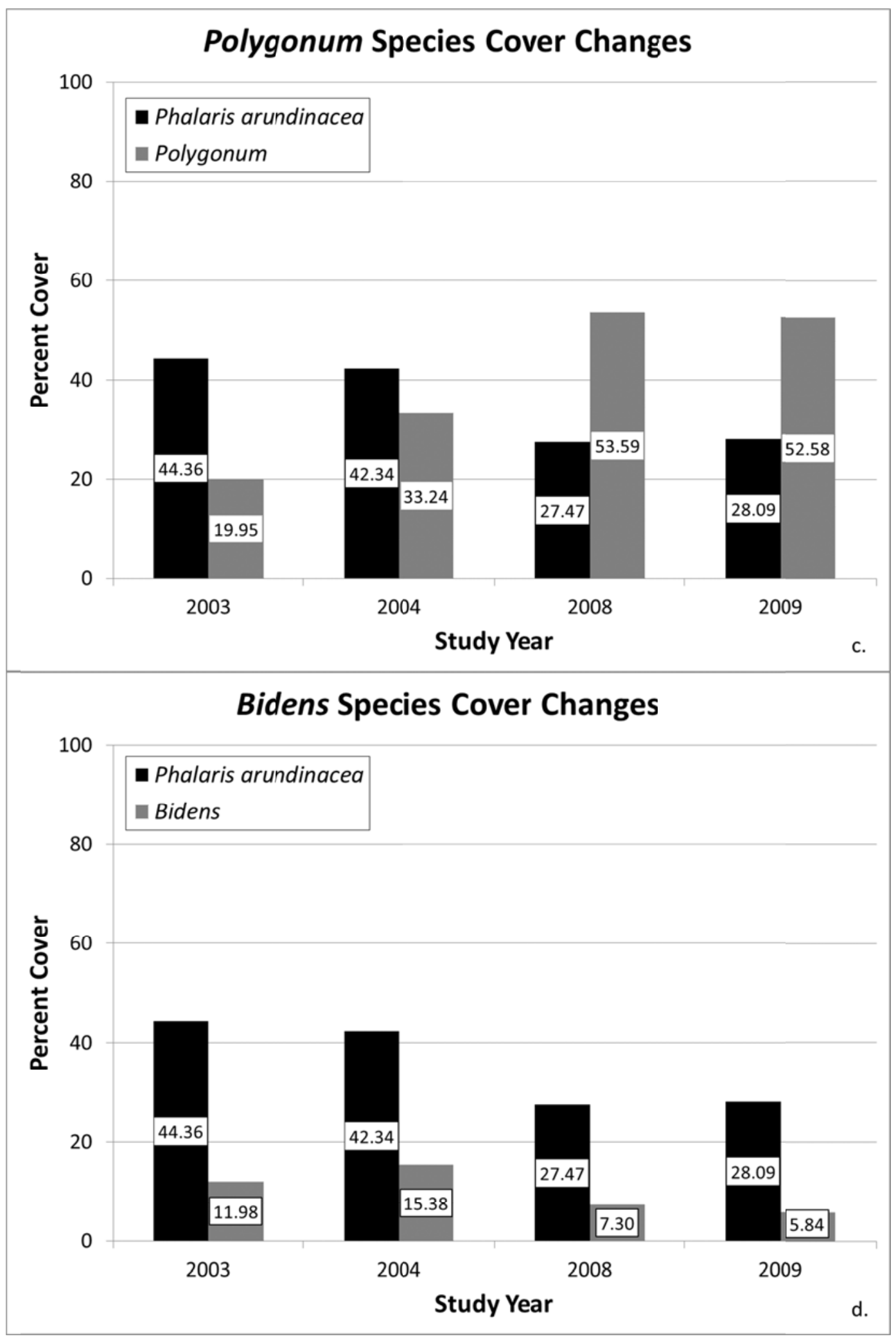




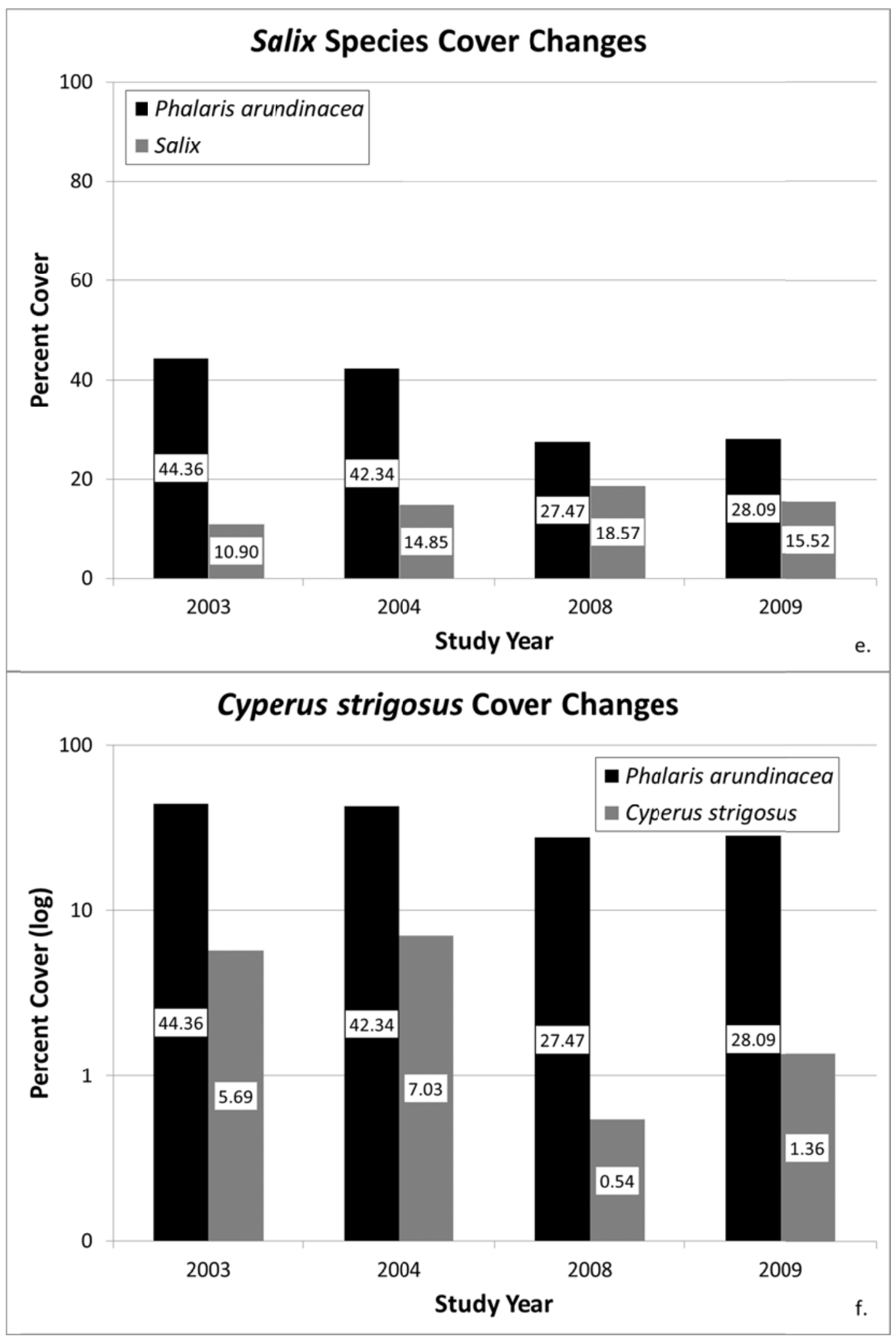




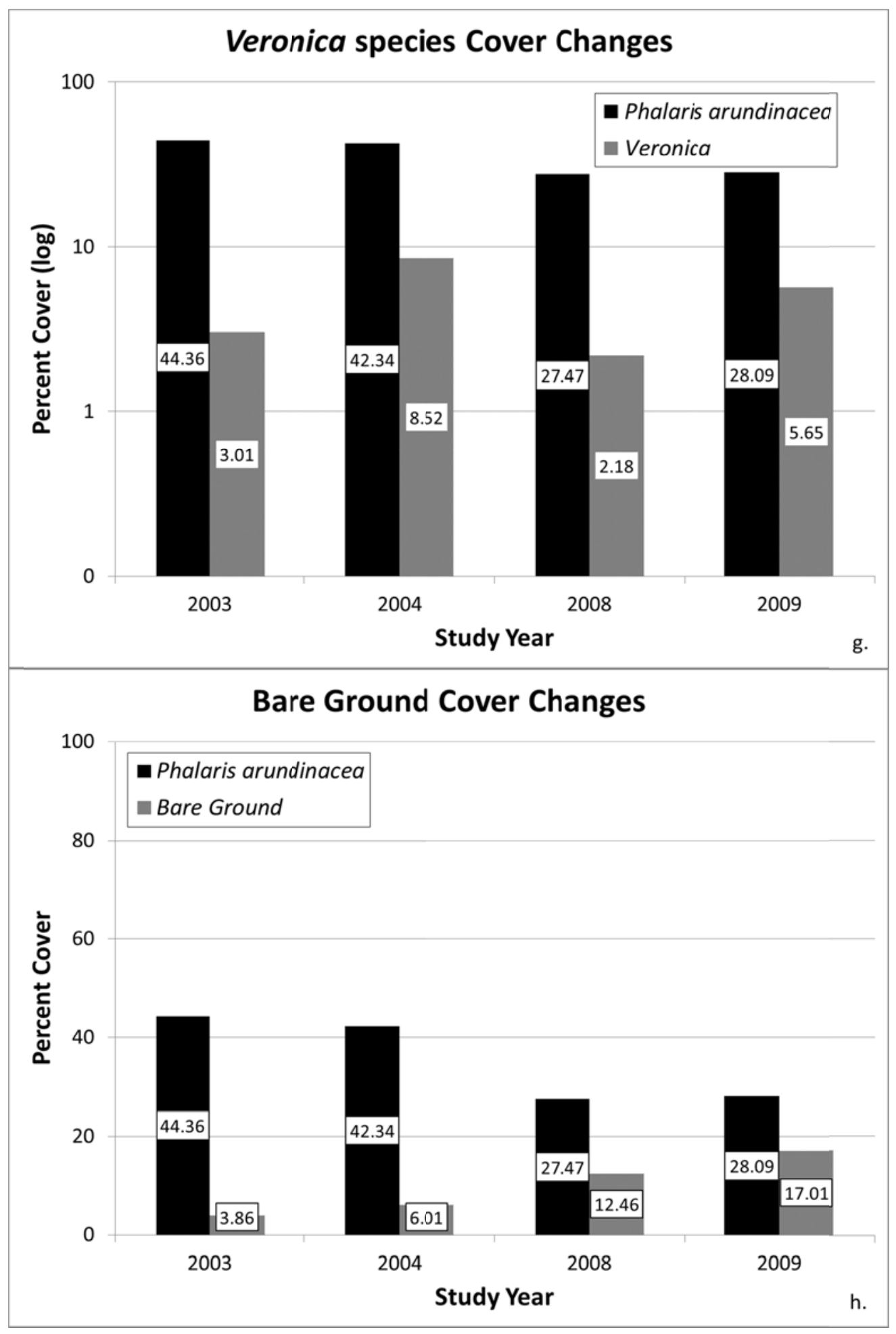

Figure 11 a.-h.: Major Cover Changes.

This figure shows the dominant species and bare ground overall percent cover by study year. The X-axis is the year of data collection for the study. The Y-axis is percent cover. Note that the y-axes in Figure $11 \mathrm{f}$ and Figure $11 \mathrm{~g}$ are in $\log$ scale. 
The percent cover of invasive plant species also changed throughout the study years (Table 9 and Figure 12). Iris pseudacorus, Lysimachia nummularia L., Lythrum salicaria, and Myriophyllum aquaticum ${ }^{16}$ increased in percent cover. Cirsium species, Lotus corniculatus, Rubus armeniacus Focke, and Solanum species decreased in abundance overall. There were differences among invasive response between Smith Lake and Bybee Lake (Appendix B). Generally, the cover of invasive plants that are more likely to occur in uplands decreased while invasive plants that are more likely to be found in wetlands increased. Invasive species that are equally likely to occur in wetlands or uplands (FAC species) decreased in cover.

\footnotetext{
${ }^{16}$ M. aquaticum percent cover is from the Smith subset of the study area as M. aquaticum populations within the Bybee subset were treated with herbicide during study years.
} 
Table 9: Invasive Species Cover Changes.

Percent cover of invasive plants for each of the years for which vegetation data are available. Bold indicates that the percent cover change is significant ( $p$-value $<0.05$ ). Species are listed in order according to the likelihood that they occur in wetlands, beginning with the least likely to be found in wetlands according to the National List of Plants the Occur in Wetlands, Region 9 (USFWS 1988, USFWS 1993).

\begin{tabular}{|c|c|c|c|c|c|c|c|c|}
\hline Species & $\begin{array}{l}\text { Wetland } \\
\text { Indicator } \\
\text { Status } \\
\text { (Upland } \\
\rightarrow \\
\text { Wetland) }\end{array}$ & $\begin{array}{l}2003 \\
\text { Percent } \\
\text { Cover }\end{array}$ & $\begin{array}{l}2004 \\
\text { Percent } \\
\text { Cover }\end{array}$ & $\begin{array}{l}2008 \\
\text { Percent } \\
\text { Cover }\end{array}$ & $\begin{array}{l}2009 \\
\text { Percent } \\
\text { Cover }\end{array}$ & $\begin{array}{l}\text { Percent } \\
\text { Cover } \\
\text { Change } \\
2004-- \\
2003\end{array}$ & $\begin{array}{l}\text { Percent } \\
\text { Cover } \\
\text { Change } \\
2008- \\
2003\end{array}$ & $\begin{array}{l}\text { Percent } \\
\text { Cover } \\
\text { Change } \\
2009- \\
2003\end{array}$ \\
\hline $\begin{array}{l}\text { Hypericum } \\
\text { perforatum }\end{array}$ & NOL & 0.05 & 0.00 & 0.00 & 0.00 & -0.05 & -0.05 & -0.05 \\
\hline $\begin{array}{l}\text { Rubus } \\
\text { armeniacus }\end{array}$ & FACU & 0.63 & 0.39 & 0.03 & 0.01 & -0.23 & -0.59 & -0.61 \\
\hline $\begin{array}{l}\text { Cirsium } \\
\text { species }\end{array}$ & $\begin{array}{l}\text { FACU+, } \\
\text { FACU }\end{array}$ & 1.04 & 0.65 & 0.15 & 0.05 & -0.39 & -0.89 & -0.98 \\
\hline $\begin{array}{l}\text { Dipsacus } \\
\text { fullonum }\end{array}$ & FAC & 0.10 & 0.00 & 0.00 & 0.00 & -0.10 & -0.10 & -0.10 \\
\hline $\begin{array}{l}\text { Lotus } \\
\text { corniculatus }\end{array}$ & FAC & 1.54 & 0.74 & 0.00 & 0.00 & -0.79 & -1.54 & -1.54 \\
\hline $\begin{array}{l}\text { Solanum } \\
\text { species }\end{array}$ & FAC + & 1.37 & 2.46 & 0.54 & 0.40 & 1.08 & -0.83 & -0.98 \\
\hline $\begin{array}{l}\text { Lysimachia } \\
\text { nummularia }\end{array}$ & FACW & 0.02 & 0.05 & 0.21 & 0.23 & 0.03 & 0.19 & 0.22 \\
\hline $\begin{array}{l}\text { Lythrum } \\
\text { salicaria }\end{array}$ & FACW+ & 0.05 & 0.16 & 0.12 & 0.28 & 0.11 & 0.07 & 0.23 \\
\hline $\begin{array}{l}\text { Iris } \\
\text { pseudacorus }\end{array}$ & $\overline{\mathrm{OBL}}$ & 0.00 & 0.01 & 0.18 & 0.31 & 0.01 & 0.18 & 0.31 \\
\hline $\begin{array}{l}\text { Myriophyllum } \\
\text { aquaticum }\end{array}$ & $\overline{\mathrm{OBL}}$ & 0.37 & 0.98 & 6.34 & 5.31 & 0.61 & 5.97 & 4.94 \\
\hline
\end{tabular}




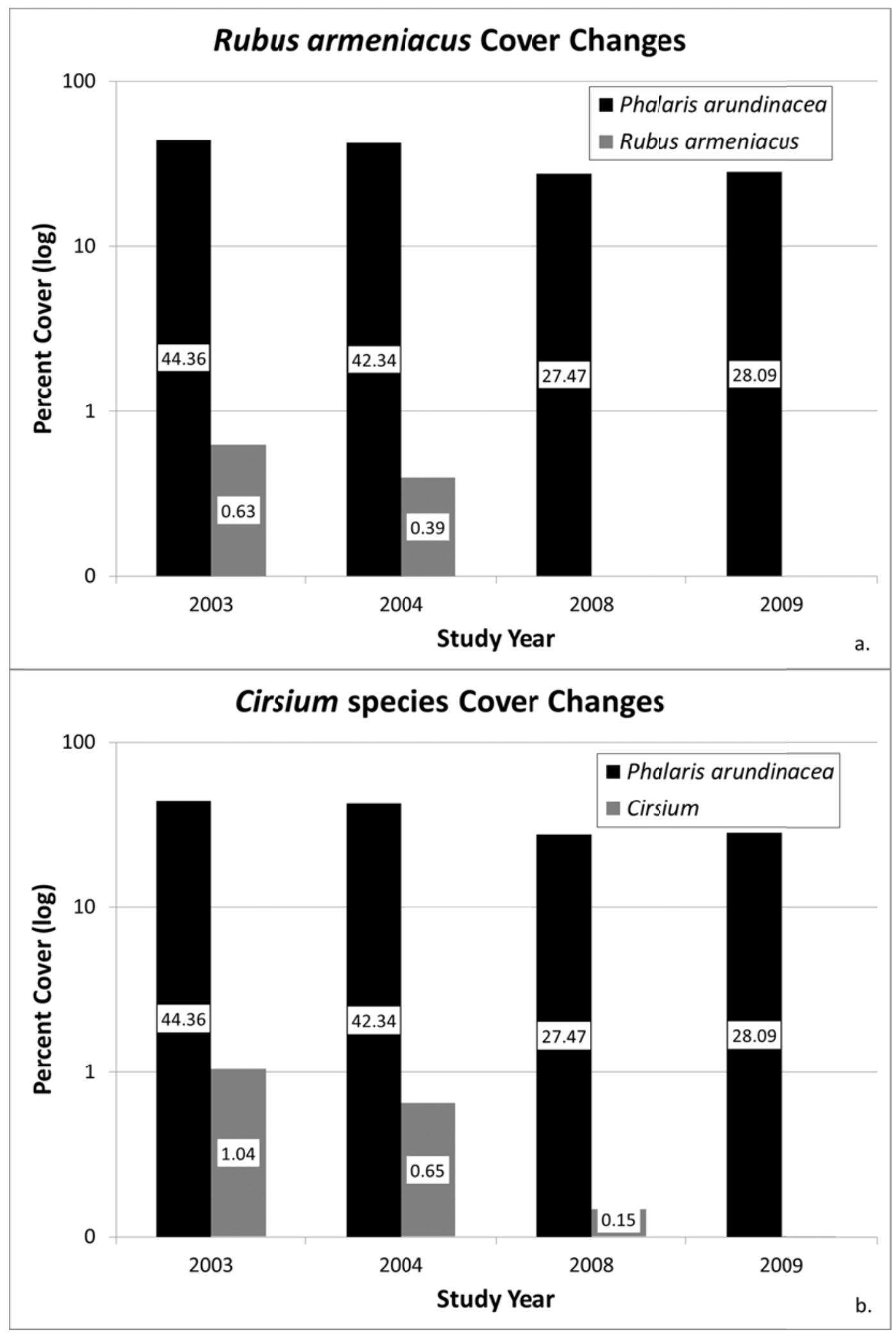




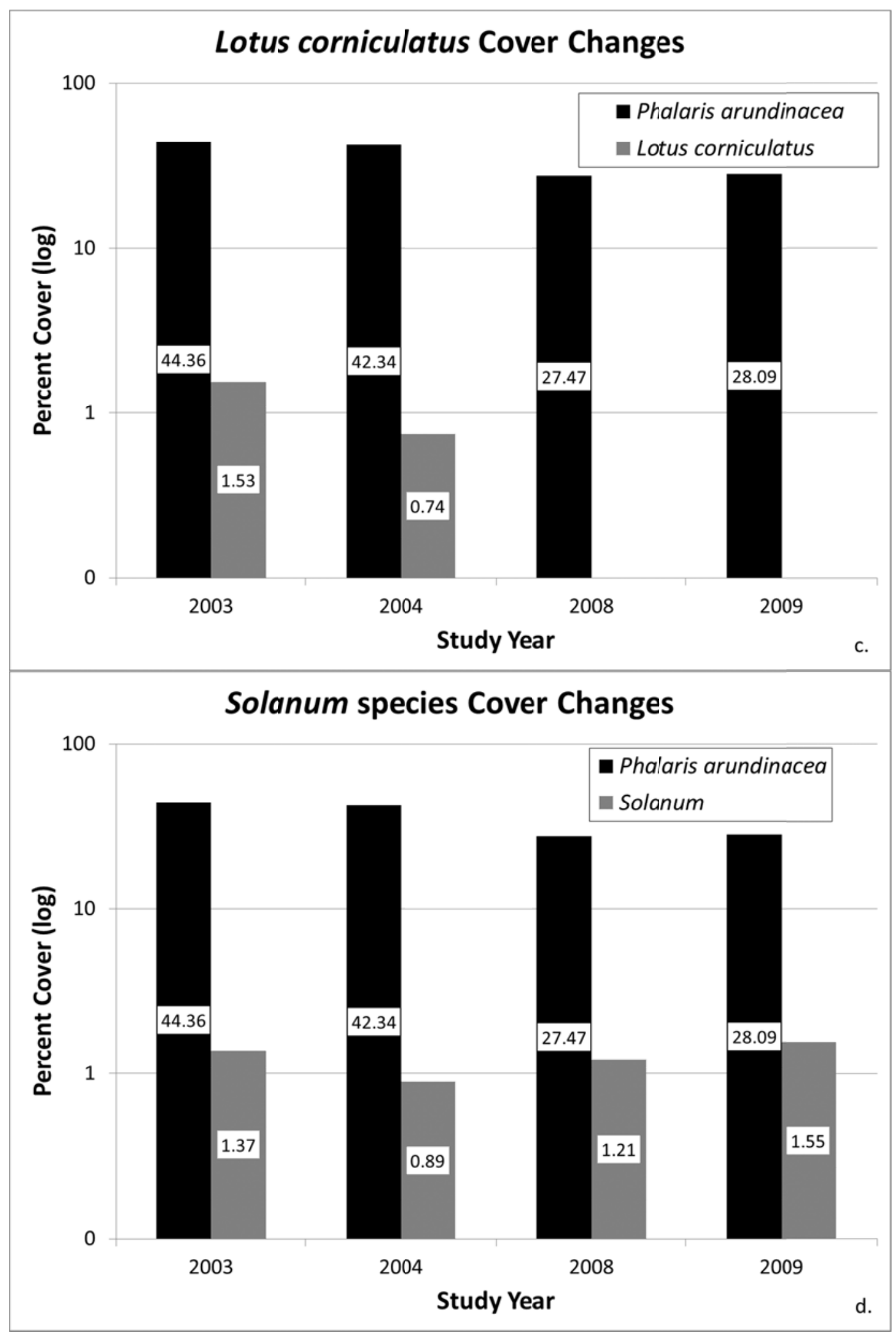




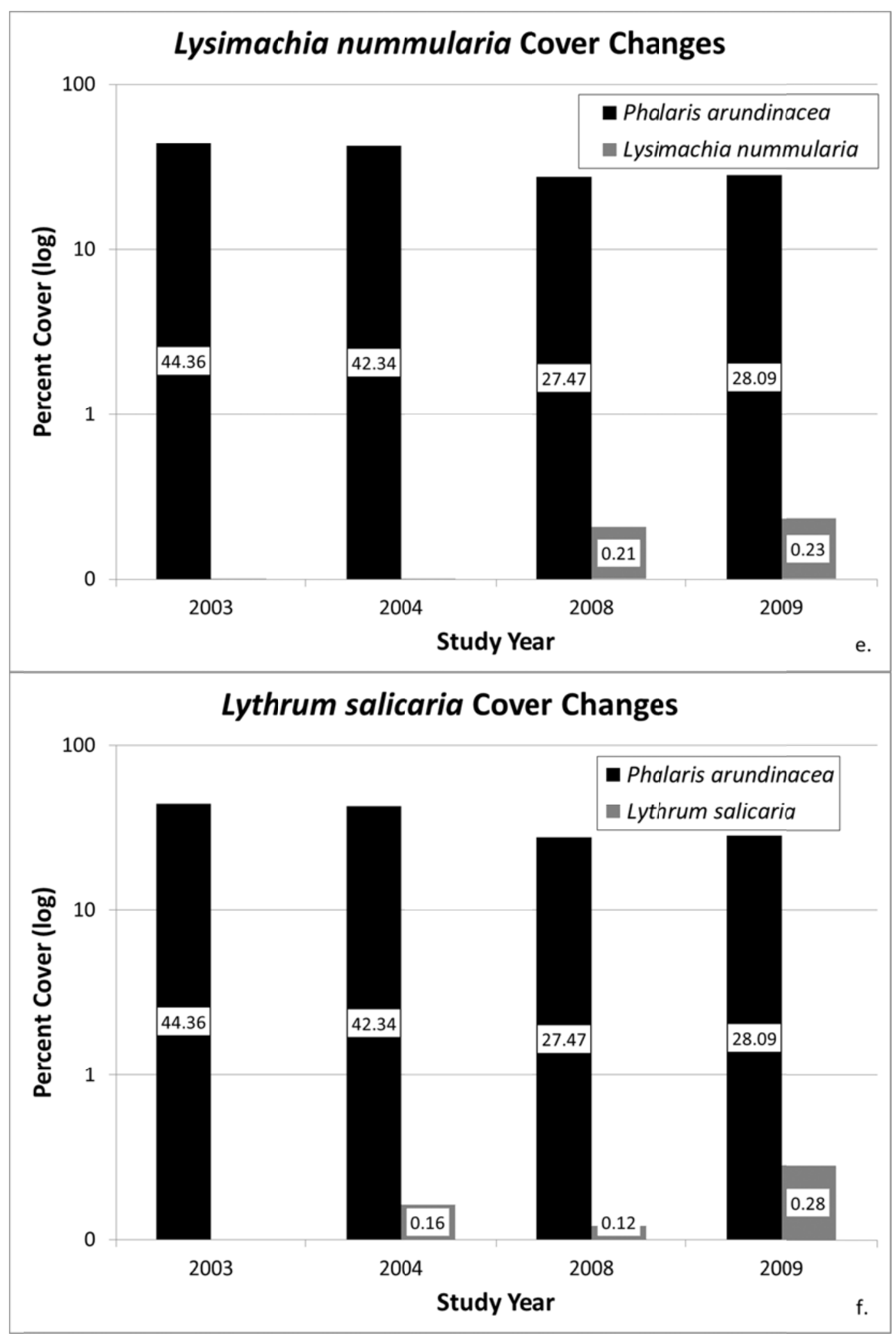




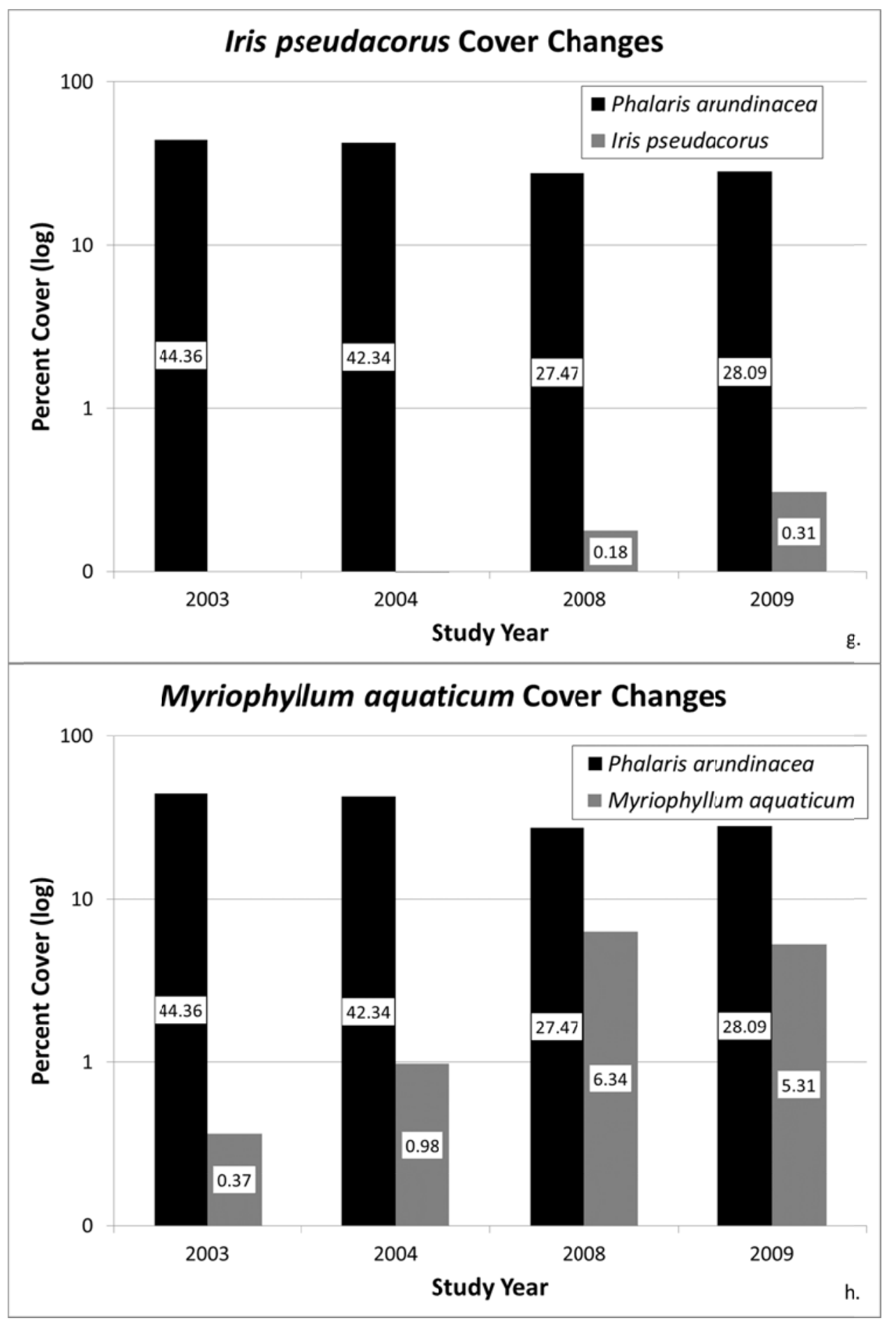

Figure 12 a.-h.: Invasive Species Cover Changes.

This figure shows the overall percent cover of invasive species (log scale) by study year. The X-axis is the year of data collection for the study. The Y-axis is percent cover. Note: Hypericum perforatum and Dipsacus fullonum are not included in the figure as their extremely small cover values precluded graphical representation. Myriophyllum aquaticum cover is only from Smith Lake. 
The percent cover of rare species and other species that are target components of the native bottomland community also changed between 2003 and 2009 (Table 10 and Figure 13). In some cases, such as with Carex and Fraxinus latifolia, the presumed response to the new water regime resulted in an increase in overall cover. Other species, such as Leersia oryzoides, Myosotis laxa, and Deschampsia cespitosa, disappeared from the transects altogether between 2003 and 2009. There were notable differences between rare and other native bottomland species responses between Smith Lake and Bybee Lake (Appendix B). 
Table 10: Minor Cover Changes.

This table shows the percent cover of rare and/or native bottomland species for each of the years for which vegetation data are available. Bold indicates that the percent cover change is significant ( $\mathrm{p}$-value $<0.05$ ).

\begin{tabular}{|c|c|c|c|c|c|c|c|}
\hline Species & $\begin{array}{l}2003 \\
\text { Percent } \\
\text { Cover } \\
\end{array}$ & $\begin{array}{l}2004 \\
\text { Percent } \\
\text { Cover }\end{array}$ & $\begin{array}{l}2008 \\
\text { Percent } \\
\text { Cover }\end{array}$ & $\begin{array}{l}2009 \\
\text { Percent } \\
\text { Cover }\end{array}$ & $\begin{array}{l}\text { Percent } \\
\text { Cover } \\
\text { Change, } \\
2004- \\
2003\end{array}$ & $\begin{array}{l}\text { Percent } \\
\text { Cover } \\
\text { Change, } \\
2008- \\
2003\end{array}$ & $\begin{array}{l}\text { Percent } \\
\text { Cover } \\
\text { Change, } \\
2009- \\
2003\end{array}$ \\
\hline \multicolumn{8}{|c|}{ Herbaceous Species } \\
\hline \multicolumn{8}{|c|}{ Increase in Cover } \\
\hline $\begin{array}{l}\text { Carex } \\
\text { species }\end{array}$ & 0.33 & 1.03 & 2.53 & 2.35 & 0.70 & 2.20 & 2.02 \\
\hline $\begin{array}{l}\text { Gnaphalium } \\
\text { species }\end{array}$ & 0.85 & 1.42 & 3.09 & 4.18 & 0.57 & 2.24 & 3.33 \\
\hline $\begin{array}{l}\text { Rorippa } \\
\text { curvisiliqua }\end{array}$ & 1.71 & 2.05 & 2.00 & 1.87 & 0.34 & 0.29 & 0.16 \\
\hline \multicolumn{8}{|c|}{ Decrease in cover following an initial (2004) increase in cover } \\
\hline $\begin{array}{l}\text { Deschampsia } \\
\text { cespitosa }\end{array}$ & 0.00 & 0.09 & 0.00 & 0.00 & 0.09 & 0.00 & 0.00 \\
\hline $\begin{array}{l}\text { Eleocharis } \\
\text { species }\end{array}$ & 3.54 & 4.60 & 1.74 & 2.50 & 1.05 & -1.80 & -1.05 \\
\hline $\begin{array}{l}\text { Eragrostis } \\
\text { hypnoides }\end{array}$ & 0.00 & 4.44 & 0.01 & 2.10 & 4.44 & 0.01 & 2.10 \\
\hline $\begin{array}{l}\text { Leersia } \\
\text { oryzoides }\end{array}$ & 0.12 & 0.61 & 0.00 & 0.00 & 0.49 & -0.12 & -0.12 \\
\hline $\begin{array}{l}\text { Myosotis } \\
\text { laxa }\end{array}$ & 0.04 & 0.30 & 0.00 & 0.00 & 0.26 & -0.04 & -0.04 \\
\hline \multicolumn{8}{|c|}{ Decrease in cover } \\
\hline $\begin{array}{l}\text { Eleocharis } \\
\text { palustris }\end{array}$ & 1.84 & 0.41 & 0.86 & 1.27 & -1.43 & -0.98 & -0.57 \\
\hline $\begin{array}{l}\text { Epilobium } \\
\text { ciliatum }\end{array}$ & 0.84 & 0.60 & 0.01 & 0.08 & -0.24 & -0.83 & -0.76 \\
\hline $\begin{array}{l}\text { Ranunculus } \\
\text { species }\end{array}$ & 1.22 & 0.03 & 0.00 & 0.00 & -1.18 & -1.22 & -1.21 \\
\hline $\begin{array}{l}\text { Rumex } \\
\text { species }\end{array}$ & 2.36 & 1.04 & 0.20 & 0.88 & -1.32 & -2.16 & -1.47 \\
\hline \multicolumn{8}{|c|}{ Shrub and Tree Species } \\
\hline $\begin{array}{l}\text { Cornus } \\
\text { sericea }\end{array}$ & 0.00 & 0.05 & 0.30 & 0.30 & 0.05 & $\mathbf{0 . 3 0}$ & 0.30 \\
\hline $\begin{array}{l}\text { Spiraea } \\
\text { douglasii }\end{array}$ & 0.00 & 0.00 & 0.06 & 0.08 & 0.00 & 0.06 & 0.08 \\
\hline $\begin{array}{l}\text { Fraxinus } \\
\text { latifolia }\end{array}$ & 0.29 & 0.54 & 1.48 & 1.77 & 0.25 & 1.19 & 1.48 \\
\hline $\begin{array}{l}\text { Populus } \\
\text { balsamifera }\end{array}$ & 0.93 & 0.84 & 1.00 & 0.97 & -0.08 & 0.07 & 0.05 \\
\hline
\end{tabular}




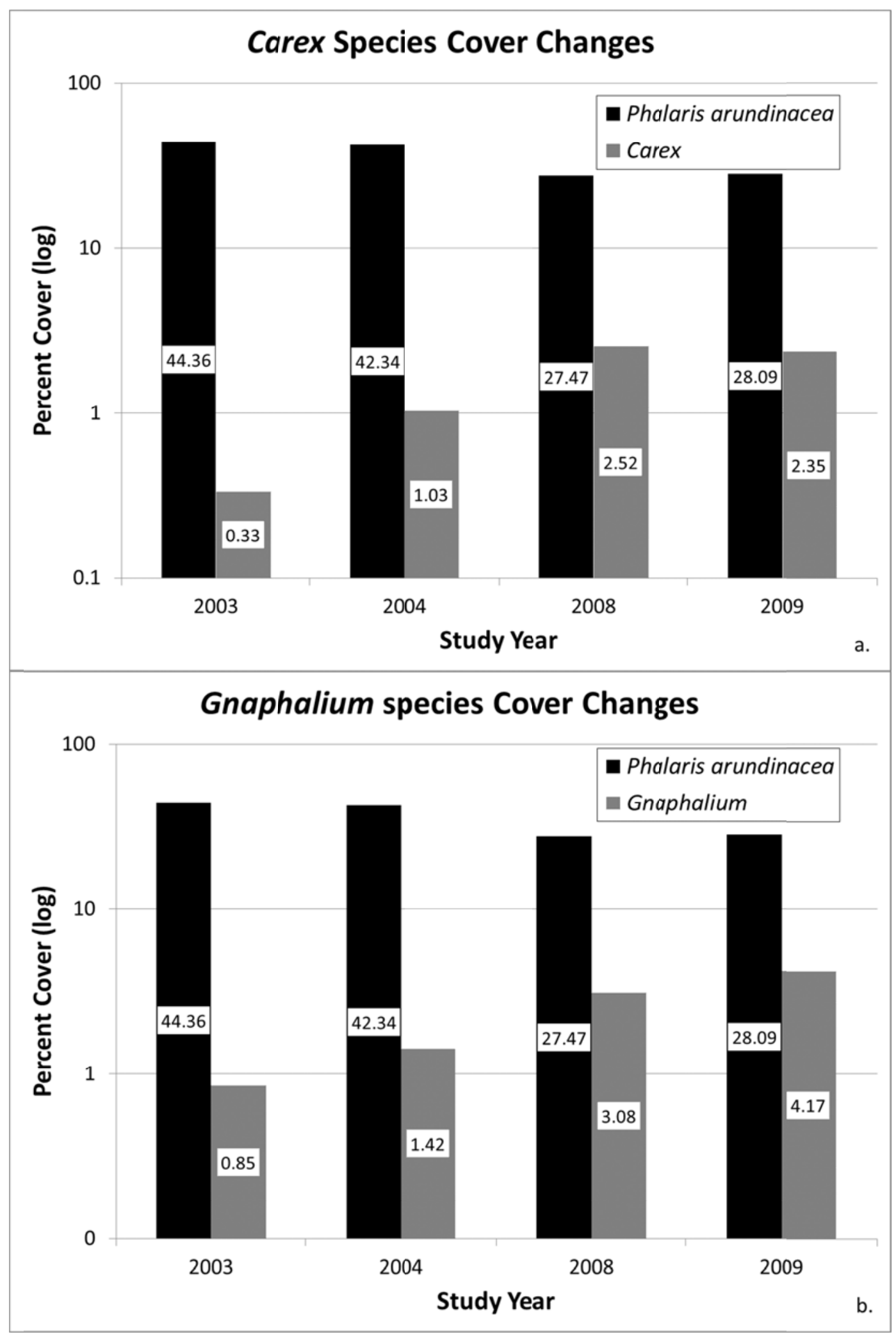




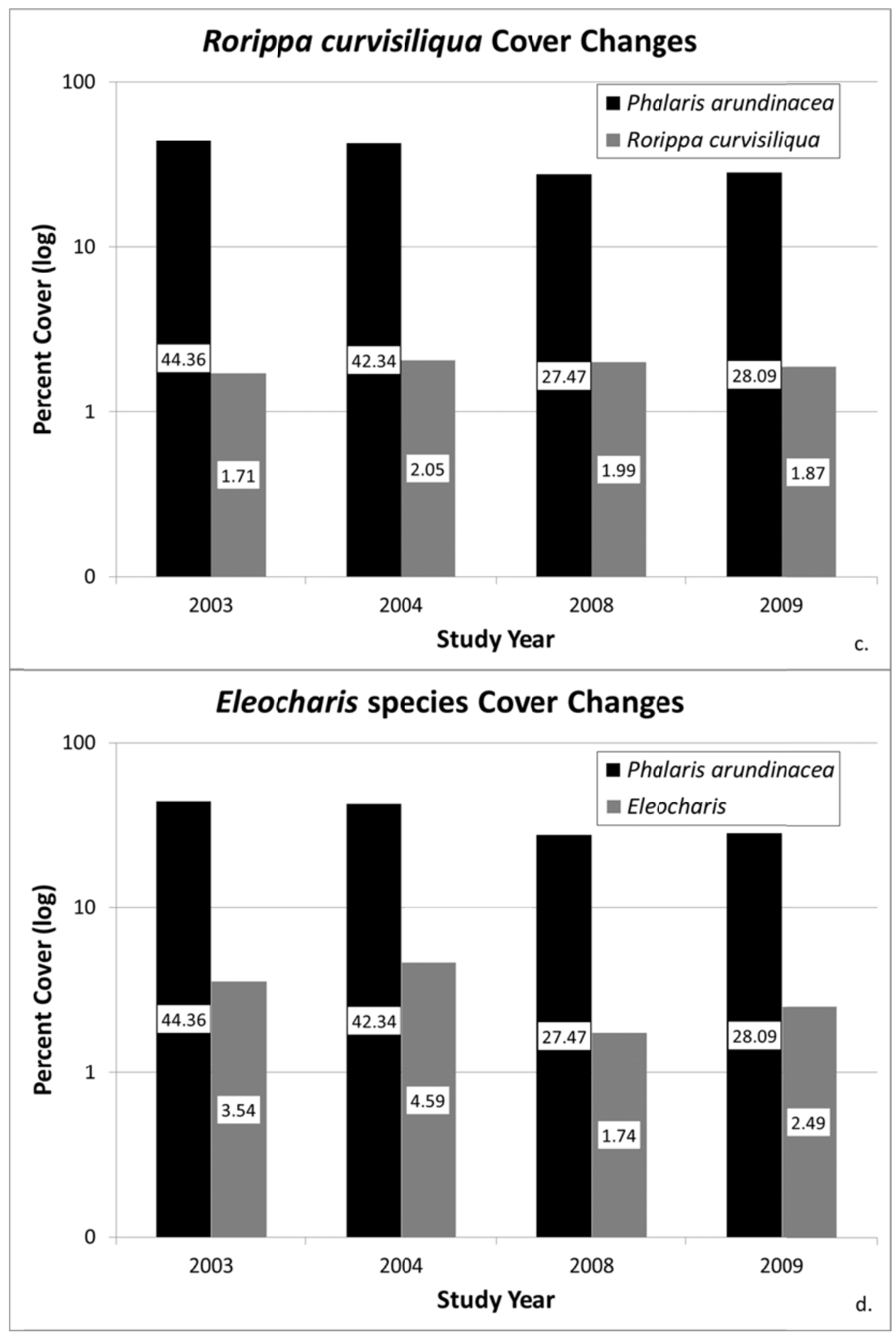




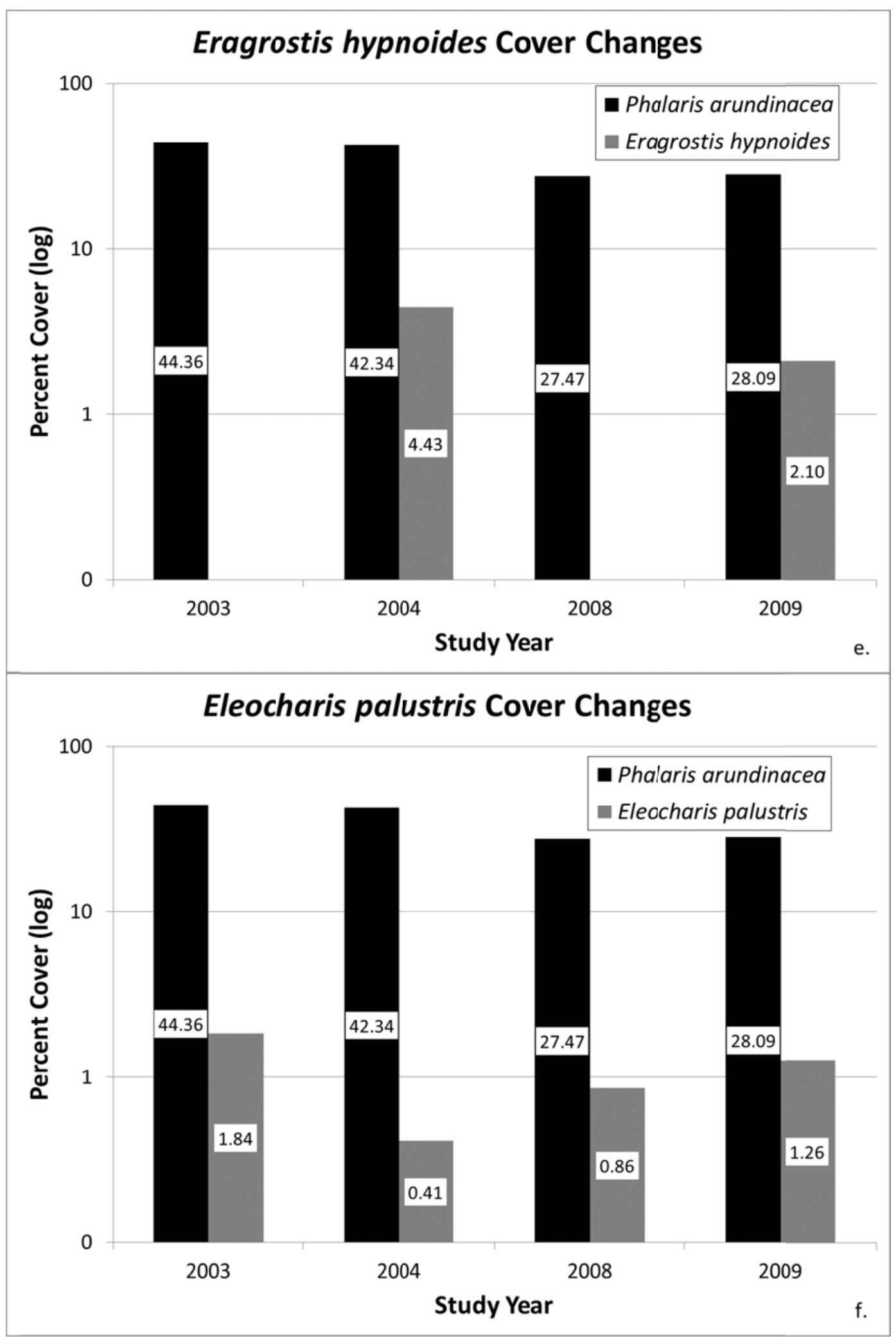




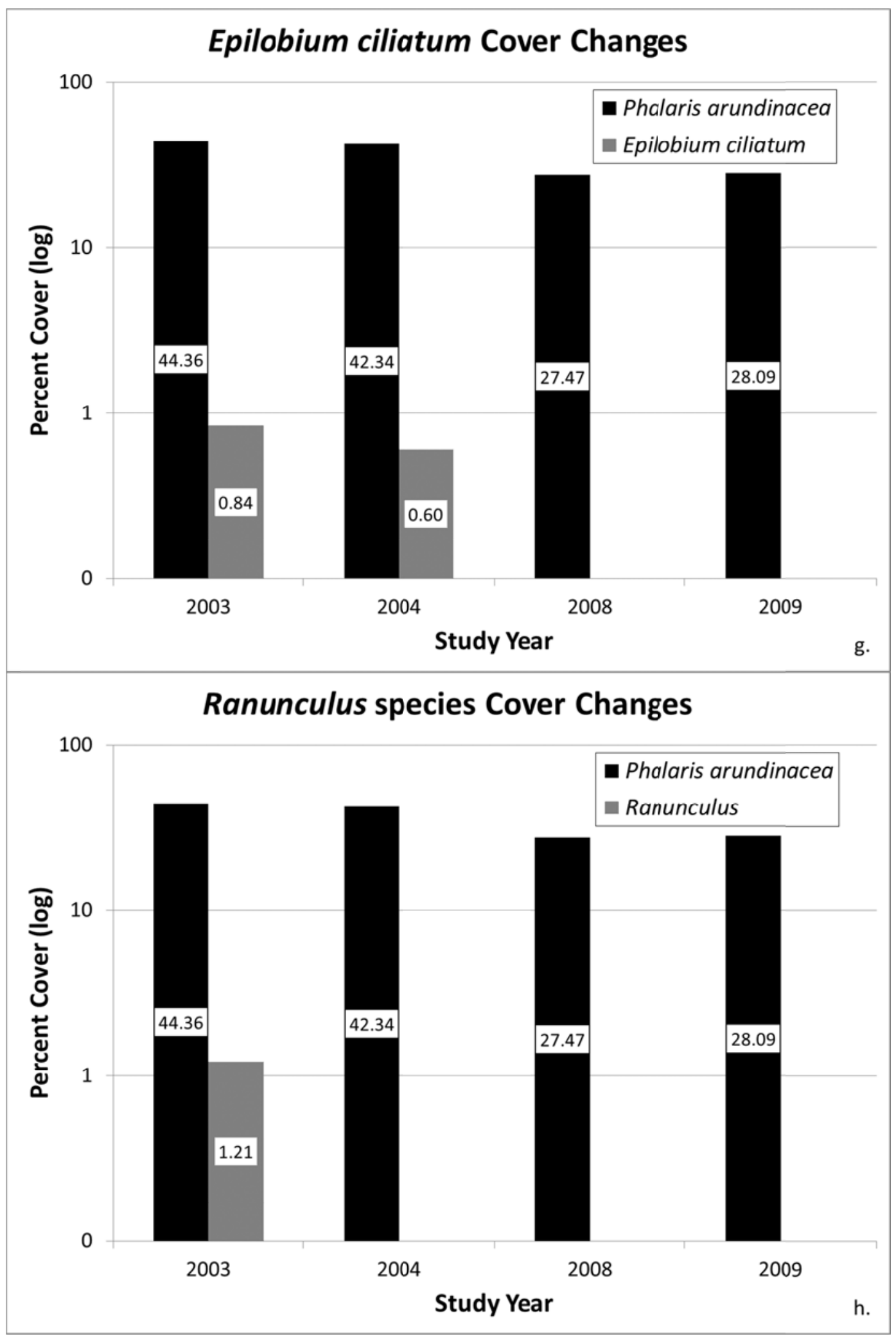




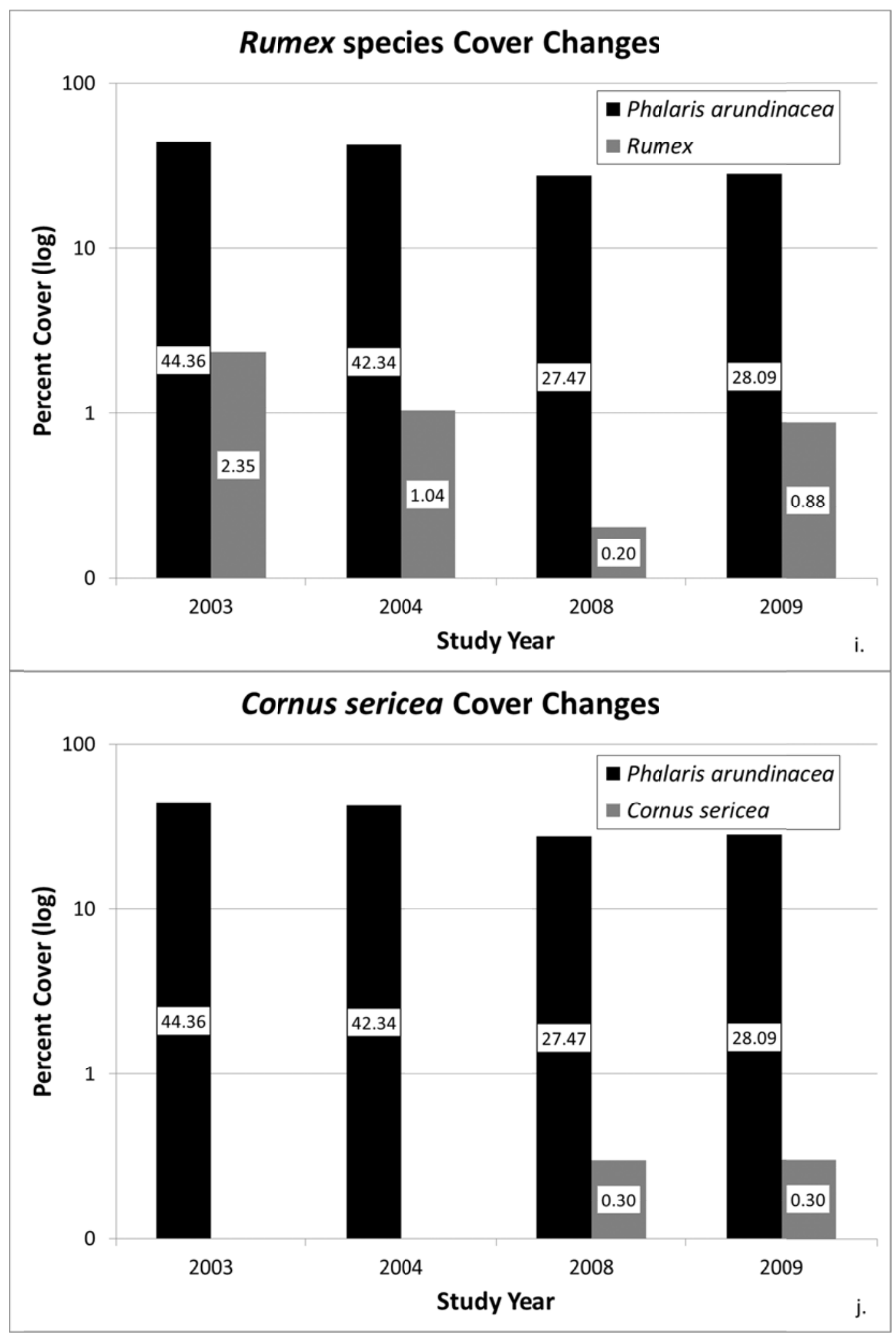




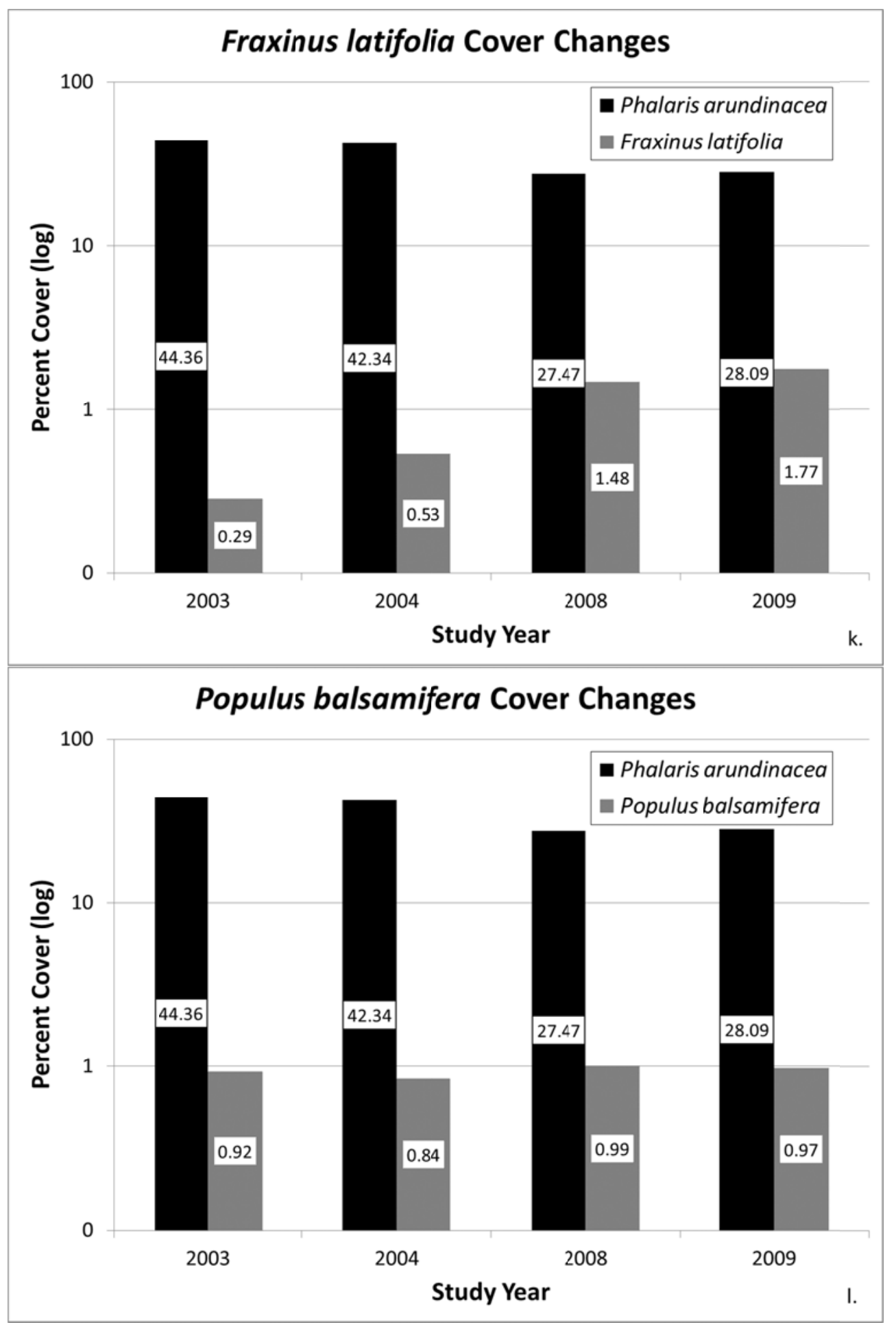

Figure 13 a.-1.: Minor Cover Changes.

This figure shows the overall percent cover of rare and/or native bottomland species by study year. The Xaxis is the year of data collection for the study. The Y-axis is percent cover. Only species with enough cover to be visualized graphically are represented in this figure. 
The percent cover changes and results of the McNemar test for the significance of these changes are summarized in Table 11 for each species found within the full study area. Most importantly for this study, Phalaris decreased significantly in cover in response to the new water management regime. In contrast, Polygonum, Salix, and Carex increased significantly.

Table 11: Cover Change Significance.

This table shows the relative cover changes and McNemar chi-squared test results for species in the overall study area.

\begin{tabular}{|c|c|c|c|c|c|c|}
\hline \multirow[b]{2}{*}{ Species } & \multicolumn{3}{|c|}{2003 to 2008} & \multicolumn{3}{|l|}{2003 to 2009} \\
\hline & $\begin{array}{l}\text { \% Cover } \\
\text { Change } \\
\end{array}$ & $\begin{array}{l}\text { McNemar } \\
\text { chi-sq }\end{array}$ & p-value & $\begin{array}{l}\text { \% Cover } \\
\text { Change }\end{array}$ & $\begin{array}{l}\text { McNemar } \\
\text { chi-sq }\end{array}$ & $\begin{array}{l}p \text { - } \\
\text { value }\end{array}$ \\
\hline \multicolumn{7}{|l|}{ Non-Natives } \\
\hline \multicolumn{7}{|l|}{ Decrease in Cover } \\
\hline Phalaris arundinacea & -16.9 & 2743.8 & $<0.001$ & -16.3 & 2587.5 & $<0.001$ \\
\hline Louts corniculatus & -1.5 & 368.0 & $<0.001$ & -1.5 & 368.0 & $<0.001$ \\
\hline Cirsium species & -0.9 & 162.0 & $<0.001$ & -1.0 & 210.8 & $<0.001$ \\
\hline Solanum species & -0.8 & 93.2 & $<0.001$ & -1.0 & 128.8 & $<0.001$ \\
\hline Rubus armeniacus & -0.6 & 126.8 & $<0.001$ & -0.6 & 140.3 & $<0.001$ \\
\hline Dipsacus fullonum & -0.1 & 21.0 & $<0.001$ & -0.1 & 21.0 & $<0.001$ \\
\hline Mentha arvensis & -0.1 & 22.0 & $<0.001$ & -0.1 & 22.0 & $<0.001$ \\
\hline Hypericum perforatum & -0.1 & 11.1 & $<0.001$ & -0.1 & 11.1 & $<0.001$ \\
\hline \multicolumn{7}{|l|}{ Increase in Cover } \\
\hline M. aquaticum ${ }^{17}$ & 5.5 & 719.7 & $<0.001$ & 4.6 & 565.5 & $<0.001$ \\
\hline Iris pseudacorus & 0.2 & 41.0 & $<0.001$ & 0.3 & 72.0 & $<0.001$ \\
\hline Lythrum salicaria & 0.1 & 5.4 & 0.02 & 0.2 & 36.0 & $<0.001$ \\
\hline \multicolumn{7}{|l|}{ No Significant Change } \\
\hline Taraxacum officinale & $<-0.1$ & 2.3 & 0.13 & $<-0.1$ & 2.3 & 0.13 \\
\hline Medicago lupulina & $<0.1$ & 1.3 & 0.25 & $<0.1$ & 1.3 & 0.25 \\
\hline Betula species & $<-0.1$ & 0 & 1 & $<-0.1$ & 0 & 1 \\
\hline Clematis vitalba & $<0.1$ & 0 & 1 & 0 & NA & NA \\
\hline Mentha species & 0 & NA & NA & 0 & NA & NA \\
\hline Hypochaeris radicata & 0 & NA & NA & $<0.1$ & 0.5 & 0.48 \\
\hline
\end{tabular}

${ }^{17}$ M. aquaticum cover is only for the Smith Lake portion of the study area. 
Table 11: Cover Change Significance.

This table shows the relative cover changes and McNemar chi-squared test results for species in the overall study area.

\begin{tabular}{|c|c|c|c|c|c|c|}
\hline \multirow[b]{2}{*}{ Species } & \multicolumn{3}{|c|}{2003 to 2008} & \multicolumn{3}{|l|}{2003 to 2009} \\
\hline & $\begin{array}{l}\text { \% Cover } \\
\text { Change }\end{array}$ & $\begin{array}{l}\text { McNemar } \\
\text { chi-sq }\end{array}$ & p-value & $\begin{array}{l}\text { \% Cover } \\
\text { Change }\end{array}$ & $\begin{array}{l}\text { McNemar } \\
\text { chi-sq }\end{array}$ & $\begin{array}{l}\text { p- } \\
\text { value }\end{array}$ \\
\hline \multicolumn{7}{|l|}{ Native Species } \\
\hline \multicolumn{7}{|l|}{ Increase in Cover } \\
\hline Polygonum & 33.7 & 6502.4 & $<0.001$ & 32.7 & 6103.7 & $<0.001$ \\
\hline Salix & 7.7 & 910.1 & $<0.001$ & 4.6 & 339.8 & $<0.001$ \\
\hline Carex & 2.2 & 444.6 & $<0.001$ & 2.0 & 409.8 & $<0.001$ \\
\hline Fraxinus latifolia & 1.2 & 275.4 & $<0.001$ & 1.5 & 349.1 & $<0.001$ \\
\hline Cornus sericea & 0.3 & 70.0 & $<0.001$ & 0.3 & 71.0 & $<0.001$ \\
\hline Spiraea douglasii & 0.1 & 12.1 & $<0.001$ & 0.1 & 18.1 & $<0.001$ \\
\hline \multicolumn{7}{|l|}{ Decrease in Cover } \\
\hline Bidens & -4.7 & 69.6 & $<0.001$ & -6.2 & 325.0 & $<0.001$ \\
\hline Cyperus strigosus & -5.1 & 1029.5 & $<0.001$ & -4.3 & 660.2 & $<0.001$ \\
\hline Eleocharis palustris & -1.0 & 85.5 & $<0.001$ & -0.6 & 26.5 & $<0.001$ \\
\hline Eleocharis species & -1.8 & 155.7 & $<0.001$ & -1.1 & 45.7 & $<0.001$ \\
\hline Epilobium ciliatum & -0.8 & 194.1 & $<0.001$ & -0.8 & 148.9 & $<0.001$ \\
\hline Leersia oryzoides & -0.1 & 26.0 & $<0.001$ & -0.1 & 26.0 & $<0.001$ \\
\hline Ludwigia palustris & -6.3 & 314.1 & $<0.001$ & -2.1 & 37.8 & $<0.001$ \\
\hline Myosotis laxa & $<-0.1$ & 8.1 & $<0.001$ & $<-0.1$ & 8.1 & $<0.001$ \\
\hline Rubus ursinus & -0.1 & 8.5 & $<0.001$ & -0.1 & 8.8 & $<0.001$ \\
\hline S. racemosa & $<-0.1$ & 7.1 & $<0.001$ & $<-0.1$ & 7.1 & $<0.001$ \\
\hline Typha latifolia & -0.1 & 30.0 & $<0.001$ & -0.1 & 30.0 & $<0.001$ \\
\hline \multicolumn{7}{|l|}{ Mixed Response } \\
\hline Eragrostis hypnoides & $<0.1$ & 0.5 & 0.48 & 2.1 & 504.0 & $<0.001$ \\
\hline Rorippa curvisiliqua & 0.3 & 4.9 & $<0.05$ & 0.2 & 1.4 & 0.23 \\
\hline S. tabernaemontani & $<-0.1$ & 5.1 & $<0.05$ & $<-0.1$ & 0.1 & 0.75 \\
\hline Veronica & -0.8 & 33.1 & $<0.001$ & 2.6 & 236.4 & $<0.001$ \\
\hline \multicolumn{7}{|l|}{ No Significant Change } \\
\hline Alisma species & $<0.1$ & 3.2 & 0.07 & 0 & NA & NA \\
\hline Deschampsia cespitosa & $<-0.1$ & 0 & 1 & $<-0.1$ & 0 & 1 \\
\hline Equisetum arvense & 0 & $\mathrm{NA}$ & NA & 0 & NA & NA \\
\hline Galium aparine & $<-0.1$ & 3.2 & 0.07 & $<-0.1$ & 3.2 & 0.07 \\
\hline Galium trifidum & 0 & NA & NA & 0 & NA & NA \\
\hline Populus balsamifera & $<0.1$ & 0.8 & 0.37 & $<0.1$ & 0.3 & 0.58 \\
\hline Ribes lacustre & $<-0.1$ & 0 & 1 & $<-0.1$ & 0 & 1 \\
\hline
\end{tabular}


Table 11: Cover Change Significance.

This table shows the relative cover changes and McNemar chi-squared test results for species in the overall study area.

\begin{tabular}{|c|c|c|c|c|c|c|}
\hline \multirow[b]{2}{*}{ Species } & \multicolumn{3}{|c|}{2003 to 2008} & \multicolumn{3}{|c|}{2003 to 2009} \\
\hline & $\begin{array}{l}\% \text { Cover } \\
\text { Change }\end{array}$ & $\begin{array}{l}\text { McNemar } \\
\text { chi-sq }\end{array}$ & p-value & $\begin{array}{l}\% \text { Cover } \\
\text { Change }\end{array}$ & $\begin{array}{l}\text { McNemar } \\
\text { chi-sq }\end{array}$ & $\begin{array}{l}\text { p- } \\
\text { value }\end{array}$ \\
\hline \multicolumn{7}{|l|}{ Unknown Species } \\
\hline \multicolumn{7}{|l|}{ Increase in Cover } \\
\hline Gnaphalium species & 2.2 & 349.1 & $<0.001$ & 3.3 & 589.7 & $<0.001$ \\
\hline \multicolumn{7}{|l|}{ Decrease in Cover } \\
\hline Juncus species & -0.6 & 146.1 & $<0.001$ & -0.6 & 149.0 & $<0.001$ \\
\hline Ranunculus species & -1.2 & 291.0 & $<0.001$ & -1.2 & 288.0 & $<0.001$ \\
\hline Rumex species & -2.2 & 436.3 & $<0.001$ & -1.5 & 160.9 & $<0.001$ \\
\hline \multicolumn{7}{|l|}{ Mixed Response } \\
\hline Unknown & 19.2 & 3085.7 & $<0.001$ & -1.0 & 27.2 & $<0.001$ \\
\hline
\end{tabular}

In all study years, areas with Salix, especially stands of more than 2 meters in length, had lower Phalaris cover. In 2003, the cover of Phalaris in Salix (Salix and Phalaris were present on the same decimeters) was 39.01 percent as opposed to 44.26 percent cover of Phalaris overall. In 2008, areas with Salix had 21.68 percent Phalaris cover and 27.33 percent cover of Phalaris overall. In 2009, areas with Salix had 22.29 percent Phalaris cover and 27.94 percent cover of Phalaris overall. In transect locations where Salix was present in both 2003 and the post management vegetation survey year (2008 or 2009), Phalaris was almost 2.5 times more likely to disappear than in the overall study area and over 3 times more likely to disappear than in transect locations without Salix. 


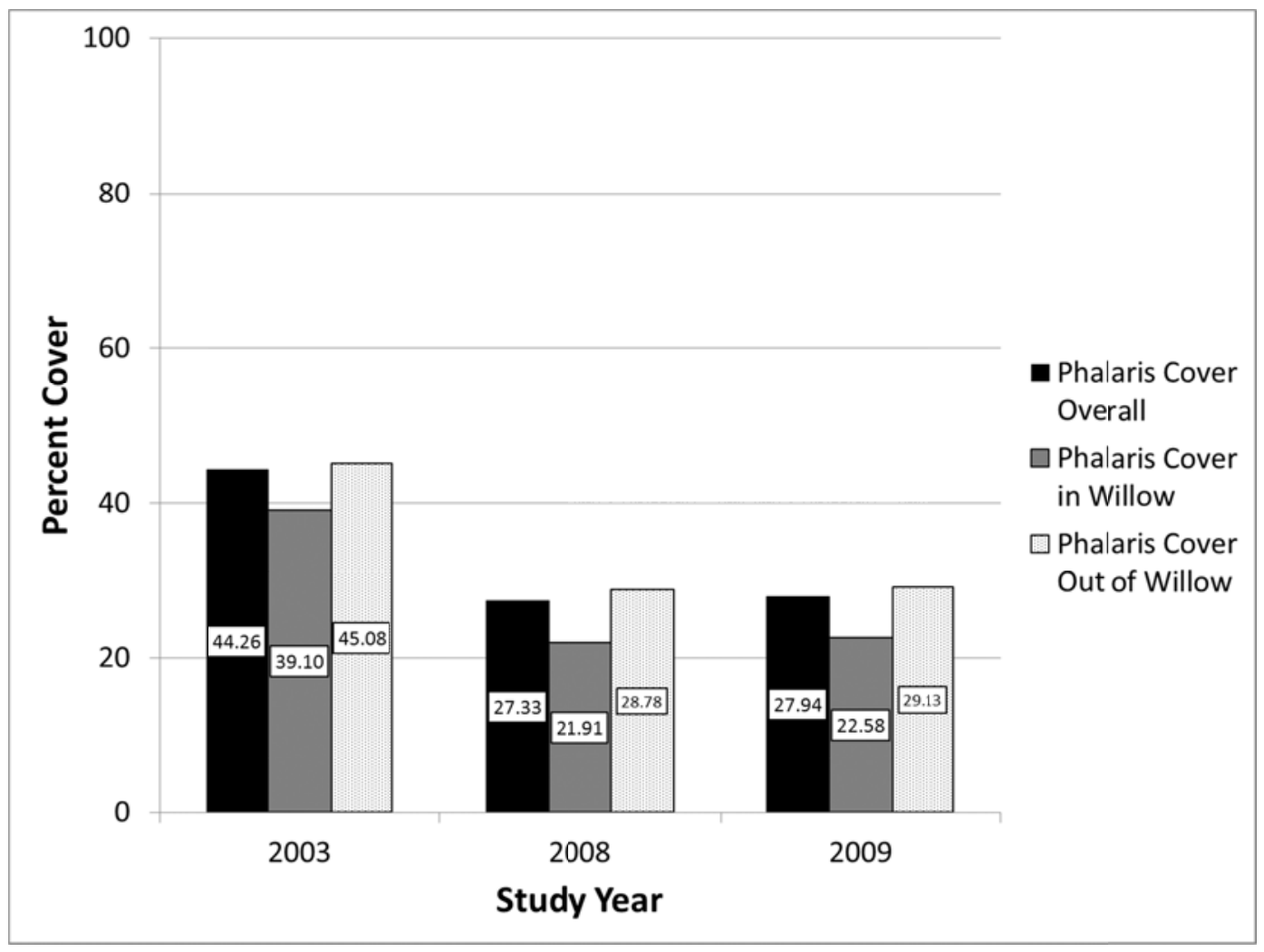

Figure 14: Phalaris and Salix Cover Relationship.

This figure shows Phalaris cover overall, in Salix, and outside of Salix for the 2003, 2008, and 2009 study years.

\section{Interaction of Phalaris arundinacea with Other Taxa}

The interaction of plant species with Phalaris in response to water management was varied. Some species were more likely to replace Phalaris in response to the new water management regime. Other species were more likely to be replaced by Phalaris in response to the new water management regime. I did not examine the physiological responses certain plant species have due to water table changes, and only report the measure of change in each instance where a species was replaced by or replaces Phalaris. These trends and their significances are reported in Table 12. 
Table 12: Phalaris Interactions.

This table shows the interaction between Phalaris arundinacea and other species and the significance of this interaction. The numbers in column 2 and column 5 represent decimeter sample locations where

Phalaris arundinacea was replaced by (first number) or replaced (second number) the given species.

\begin{tabular}{|c|c|c|c|c|c|c|}
\hline \multirow{2}{*}{$\begin{array}{l}\text { Species interacting } \\
\text { with Phalaris }\end{array}$} & \multirow{2}{*}{$\begin{array}{l}\text { \# Replacing } \\
\text { Phalaris/\# } \\
\text { Replaced by } \\
\text { Phalaris }\end{array}$} & 2008 & 2008 & \multirow{2}{*}{$\begin{array}{l}\text { \# Replacing } \\
\text { Phalaris/\# } \\
\text { Replaced } \\
\text { by Phalaris }\end{array}$} & 2009 & \multirow{2}{*}{$\begin{array}{l}2009 \\
p \text {-value }\end{array}$} \\
\hline & & $\begin{array}{l}\text { Chi- } \\
\text { squared }\end{array}$ & p-value & & $\begin{array}{l}\text { Chi- } \\
\text { squared }\end{array}$ & \\
\hline \multicolumn{7}{|c|}{ Species Replacing Phalaris } \\
\hline Polygonum & $2369 / 49$ & 2224.1 & $<0.01$ & $2362 / 53$ & 2205.7 & $<0.01$ \\
\hline Salix & $933 / 11$ & 898.6 & $<0.01$ & $648 / 17$ & 596.8 & $<0.01$ \\
\hline Carex & $57 / 20$ & 16.8 & $<0.01$ & $59 / 13$ & 28.1 & $<0.01$ \\
\hline Veronica & $153 / 11$ & 121.2 & $<0.01$ & $197 / 2$ & 189.1 & $<0.01$ \\
\hline Bidens & $341 / 60$ & 195.5 & $<0.01$ & $332 / 79$ & 154.5 & $<0.01$ \\
\hline Gnaphalium spp. & $172 / 37$ & 85.9 & $<0.01$ & $201 / 40$ & 106.2 & $<0.01$ \\
\hline Ludwigia palustris & $623 / 126$ & 328.5 & $<0.01$ & $713 / 96$ & 469.0 & $<0.01$ \\
\hline Rorippa curvisiliqua & $112 / 0$ & 110.0 & $<0.01$ & $111 / 1$ & 106.1 & $<0.01$ \\
\hline Cornus sericea & $31 / 0$ & 29.0 & $<0.01$ & $31 / 0$ & 29.0 & $<0.01$ \\
\hline Fraxinus latifolia & $21 / 0$ & 19.0 & $<0.01$ & $39 / 0$ & 37.0 & $<0.01$ \\
\hline Lythrum salicaria & $7 / 0$ & 5.1 & $<0.05$ & $8 / 0$ & 6.1 & $<0.05$ \\
\hline \multicolumn{7}{|c|}{ Species Replaced by Phalaris } \\
\hline Cirsium species & $3 / 41$ & 31.1 & $<0.01$ & $4 / 45$ & 32.7 & $<0.01$ \\
\hline Dipsacus fullonum & $0 / 6$ & 4.2 & $<0.05$ & $0 / 6$ & 4.2 & $<0.05$ \\
\hline Juncus species & $0 / 17$ & 15.1 & $<0.01$ & $0 / 10$ & 8.1 & $<0.05$ \\
\hline Rubus ursinus & $0 / 12$ & 10.1 & $<0.05$ & $1 / 12$ & 7.7 & $<0.01$ \\
\hline \multicolumn{7}{|c|}{ Mixed Results (Changes in Inter-Annual Trend or Significance) } \\
\hline Rumex species & $24 / 15$ & 1.6 & 0.20 & $130 / 15$ & 89.6 & $<0.01$ \\
\hline Eleocharis species & $84 / 66$ & 1.9 & 0.17 & $158 / 58$ & 45.4 & $<0.01$ \\
\hline Eragrostis hypnoides & $0 / 0$ & NA & NA & $50 / 0$ & 48.0 & $<0.01$ \\
\hline Cyperus strigosus & $29 / 72$ & 17.5 & $<0.01$ & $78 / 85$ & 0.2 & 0.64 \\
\hline Epilobium ciliatum & $0 / 8$ & 6.1 & $<0.05$ & $8 / 11$ & 0.2 & 0.64 \\
\hline Eleocharis palustris & $21 / 45$ & 8.0 & $<0.01$ & $46 / 40$ & 0.3 & 0.59 \\
\hline Iris pseudacorus & $4 / 0$ & 2.3 & 0.13 & $9 / 0$ & 7.1 & $<0.01$ \\
\hline Solanum species & $18 / 28$ & 1.8 & 0.18 & $4 / 19$ & 8.5 & $<0.01$ \\
\hline Unknown & $1294 / 289$ & 636.8 & $<0.01$ & $290 / 384$ & 12.8 & $<0.01$ \\
\hline \multicolumn{7}{|l|}{ No Significant Trend } \\
\hline M. aquaticum & $5 / 10$ & 1.1 & 0.30 & $55 / 54$ & 0 & 1 \\
\hline Populus balsamifera & $8 / 15$ & 1.6 & 0.21 & $10 / 16$ & 1.0 & 0.33 \\
\hline Rubus armeniacus & $6 / 8$ & 0.1 & 0.79 & $2 / 5$ & 0.6 & 0.45 \\
\hline
\end{tabular}


Polygonum, Salix, Bidens, Carex, Veronica, Gnaphalium, Ludwigia palustris, Rorippa curvisiliqua, Rumex species, Cornus sericea, and Fraxinus latifolia were much more likely (p-values less than 0.01) to replace Phalaris. Of these, Bidens and Ludwigia palustris had a negative response overall to the new water management regime (both decreased significantly in cover). Cirsium species, Dipsacus fullonum, Juncus species, and Rubus ursinus were more likely to be replaced by Phalaris. Some species showed mixed responses. Eleocharis species, Iris pseudacorus, and Eragrostis hypnoides more often replaced Phalaris, but only significantly so in one study year. Cyperus strigosus, Epilobium ciliatum, Solanum species, and Eleocharis palustris were replaced by Phalaris more often, but only significantly so in one study year. Figure 15 a. shows the species that have major interactions with Phalaris, including Bidens, Ludwigia, Polygonum, and Salix. Figure 15 b.-d. shows the species with minor, but significant interactions with Phalaris. 


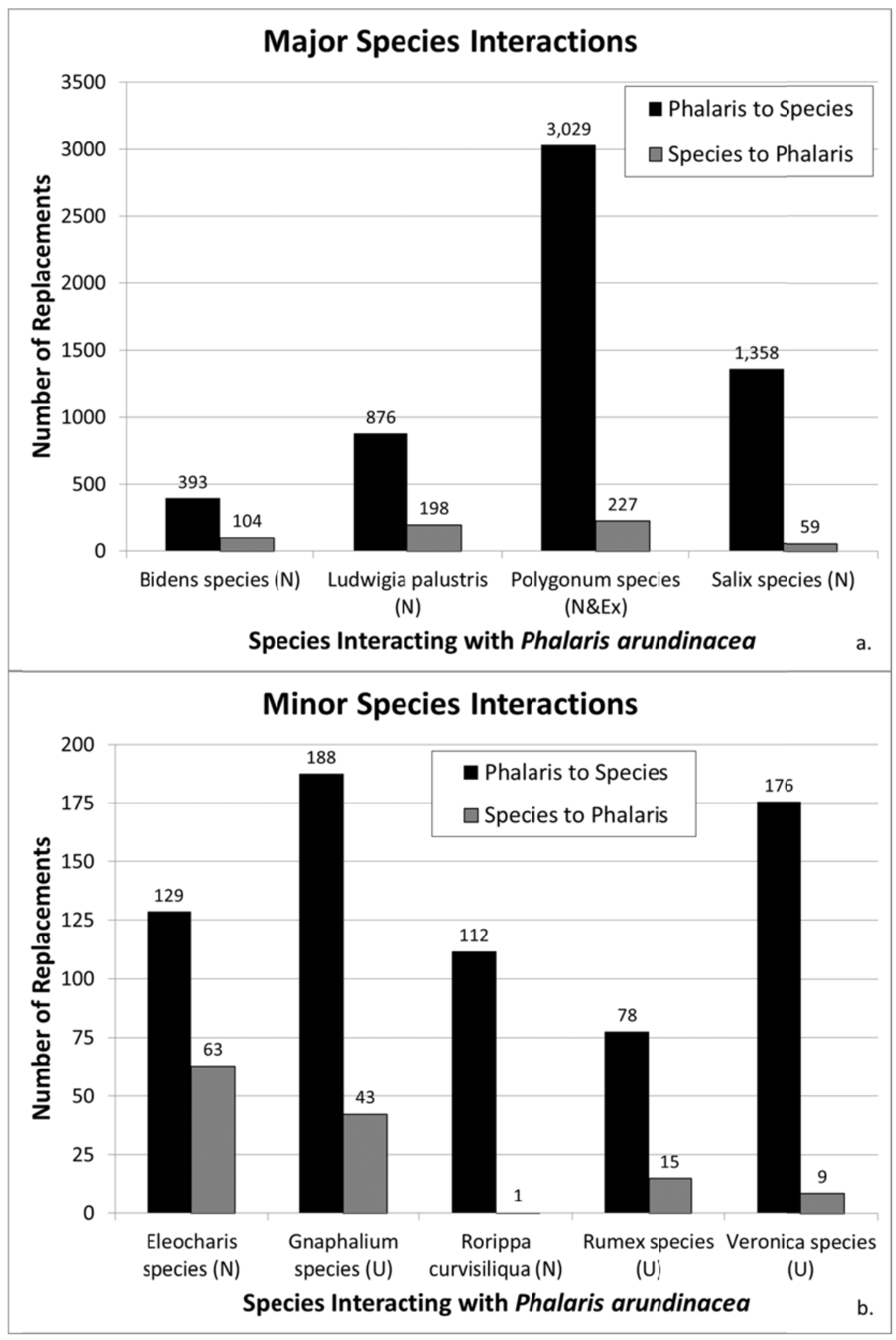




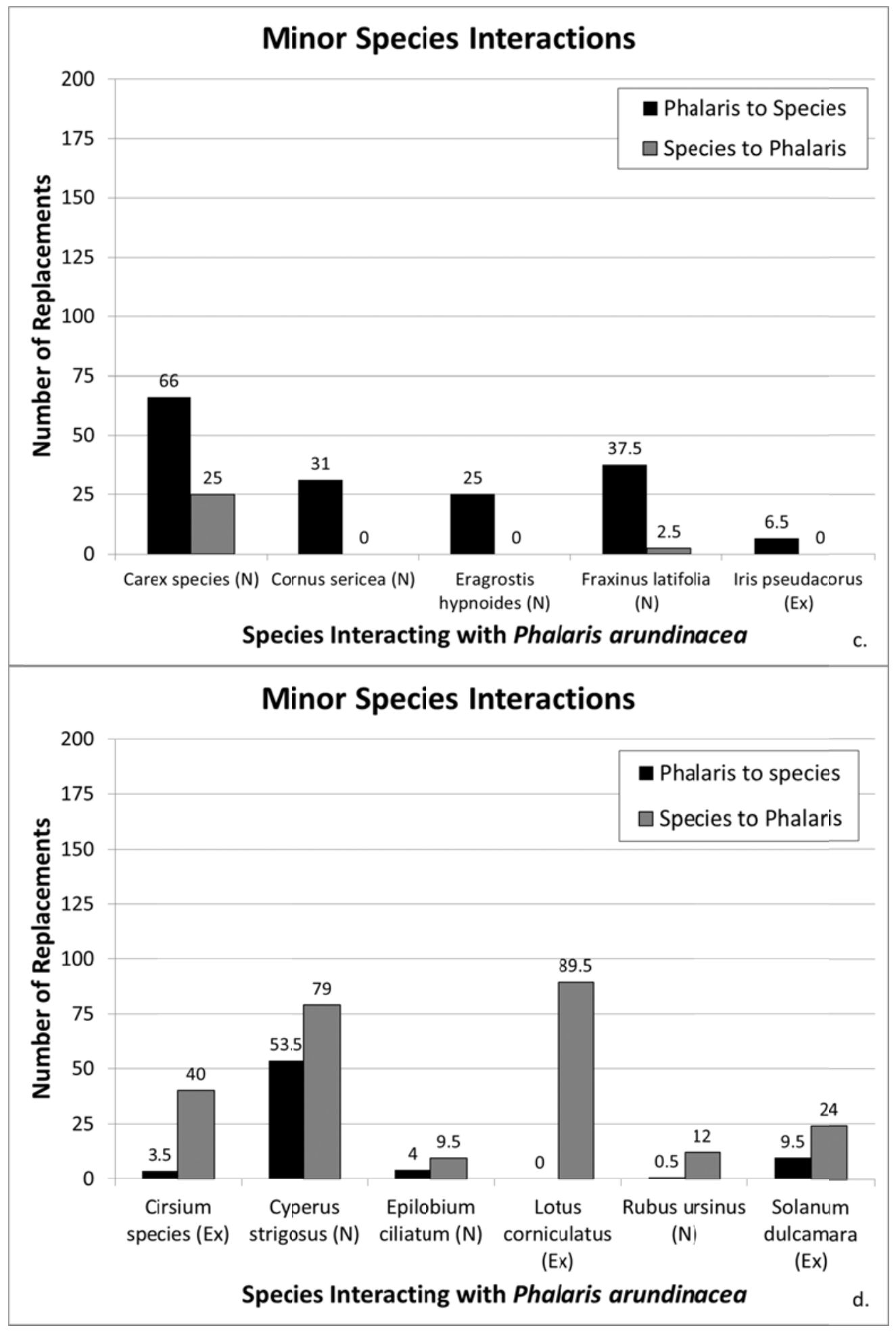

Figure 15 a.-d.: Phalaris Interactions.

Shown are species Interactions with Phalaris. Native (N), Exotic (Ex), and Unknown Origin (U) species status are noted. 


\section{Phalaris arundinacea Response to Shading and Hydrology}

The following results are based on hydrological data from 2009 and do not account for variations resulting from differences between Smith Lake and Bybee Lake due to the beaver dam. All data from Smith Lake, including data from below the elevation affected by the beaver dam, are included in this analysis. The results of multinomial logistic regression using maximum inundation and Salix presence/absence (in both 2003, prior to water management, and 2009, six years following initiation of water management) as the predictor variables and Phalaris change as the response variable are shown in Table 13. As described in the Methods section, an odds ratio value greater than 1 indicates that the Case is more likely to occur while an odds ratio value less than 1 indicates that the Case is less likely to occur than the reference case, (the reference case has a value of 1). The results indicate that deeper inundation is most likely to reduce cover of or prevent establishment of Phalaris. Salix cover was most likely to reduce the cover of Phalaris rather than prevent its establishment (except in Smith where it is more likely that Phalaris will be absent both years), increase its cover, or have no change on its presence. 
Table 13: Relationship Between Shading, Maximum Inundation, and Phalaris Cover.

This table shows the odds ratios for the multinomial logistic regression of Phalaris change, Salix cover, and hydrology. The predictor variables were Salix presence in both years (i.e., in both 2003 and 2009) and the maximum inundation for each point on the transects. The response variable for the regression is Phalaris cover change for each point on the transects. The reference case is where Phalaris was present in 2003 but absent in 2009. All odds ratios are relative to the reference case. Case 2 is where Phalaris was absent both years, Case 3 is where Phalaris was absent in 2003 but present in 2009, and Case 4 is where Phalaris was present both years. Bold indicates that the particular case is more likely to occur than the reference case.

\begin{tabular}{|c|c|c|c|c|}
\hline \multirow[b]{2}{*}{ Variable } & \multirow[b]{2}{*}{ Case } & Overall & Smith & Bybee \\
\hline & & \multicolumn{3}{|c|}{ Odds Ratio } \\
\hline Maximum Inundation & 1 & 1.00 & 1.00 & 1.00 \\
\hline Maximum Inundation & 2 & 9.05 & 8.60 & 16.8 \\
\hline Maximum Inundation & 3 & 0.02 & 0.02 & 0.02 \\
\hline Maximum Inundation & 4 & 0.01 & 0.01 & 0.01 \\
\hline Salix Present & 1 & 1.00 & 1.00 & 1.00 \\
\hline Salix Present & 2 & 0.53 & 1.54 & 0.25 \\
\hline Salix Present & 3 & 0.10 & 0.06 & 0.12 \\
\hline Salix Present & 4 & 0.07 & 0.18 & 0.03 \\
\hline
\end{tabular}

\section{Phalaris arundinacea - Polygonum species Interaction and Hydrology}

The results of a multinomial logistic regression of maximum inundation and the interaction between Phalaris and Polygonum are shown in Table 14. Generally, it was much less likely that either Phalaris or Polygonum would appear under the deepest or the longest periods of inundation. However, it was more likely that Polygonum would replace Phalaris in areas that were inundated for longer duration and greater depth than it is for Phalaris to replace Polygonum.

According to the data, it was most likely that both Phalaris and Polygonum remained absent under the wettest conditions (odds ratio $=1263.6$ ). Compared to the reference case (where Phalaris is replaced by Polygonum), it was more likely that Phalaris remained absent and Polygonum appeared where it was not present in 2003 (odds ratio $=3.1$ ), disappeared where it was present in 2003 (odds ratio $=106.0$ ), or maintained its presence where it was in 2003 (odds ratio $=2.0$ ). In the wettest conditions, 
it was also more likely that Phalaris disappeared where it was present in 2003 and

Polygonum remained absent (odds ratio $=3.4$ ) compared to the reference case.

Table 14: Maximum Inundation and Phalaris/Polygonum Interaction.

This table shows the odds ratios for multinomial logistic regression of Phalaris-Polygonum species interaction and Hydrology. The reference case $\left({ }^{*}\right)$ is where Phalaris is replaced by Polygonum species. Bold indicates that the particular case is more likely to occur than the reference case.

\begin{tabular}{|l|c|c|c|r|}
\hline Variable & Case & Phalaris $(\mathbf{2 0 0 3} \rightarrow \mathbf{2 0 0 9})$ & Polygonum $(\mathbf{2 0 0 3} \rightarrow \mathbf{2 0 0 9})$ & \multicolumn{1}{c|}{$\begin{array}{l}\text { Odds } \\
\text { Ratio }\end{array}$} \\
\hline Maximum Inundation & $1^{*}$ & Present $\rightarrow$ Absent & Absent $\rightarrow$ Present & 1.00 \\
\hline Maximum Inundation & 2 & Absent $\rightarrow$ Present & Present $\rightarrow$ Absent & 0.04 \\
\hline Maximum Inundation & $\mathbf{3}$ & Absent $\rightarrow$ Absent & Absent $\rightarrow$ Present & $\mathbf{3 . 1 1}$ \\
\hline Maximum Inundation & 4 & Present $\rightarrow$ Present & Absent $\rightarrow$ Present & 0.03 \\
\hline Maximum Inundation & 5 & Present $\rightarrow$ Absent & Present $\rightarrow$ Present & 0.74 \\
\hline Maximum Inundation & 6 & Present $\rightarrow$ Present & Present $\rightarrow$ Absent & 0.02 \\
\hline Maximum Inundation & 7 & Absent $\rightarrow$ Present & Present $\rightarrow$ Present & 0.06 \\
\hline Maximum Inundation & 8 & Absent $\rightarrow$ Present & Absent $\rightarrow$ Present & 0.06 \\
\hline Maximum Inundation & $\mathbf{9}$ & Present $\rightarrow$ Absent & Present $\rightarrow$ Absent & $\mathbf{2 5 . 7 1}$ \\
\hline Maximum Inundation & 10 & Absent $\rightarrow$ Present & Absent $\rightarrow$ Absent & $<0.01$ \\
\hline Maximum Inundation & $\mathbf{1 1}$ & Absent $\rightarrow$ Absent & Absent $\rightarrow$ Absent & $\mathbf{1 2 6 3 . 5 6}$ \\
\hline Maximum Inundation & $\mathbf{1 2}$ & Present $\rightarrow$ Absent & Absent $\rightarrow$ Absent & $\mathbf{3 . 4 3}$ \\
\hline Maximum Inundation & $\mathbf{1 3}$ & Absent $\rightarrow$ Absent & Present $\rightarrow$ Absent & $\mathbf{1 0 5 . 9 6}$ \\
\hline Maximum Inundation & $\mathbf{1 4}$ & Absent $\rightarrow$ Absent & Present $\rightarrow$ Present & $\mathbf{2 . 0 1}$ \\
\hline Maximum Inundation & 15 & Present $\rightarrow$ Present & Absent $\rightarrow$ Absent & 0.01 \\
\hline Maximum Inundation & 16 & Present $\rightarrow$ Present & Present $\rightarrow$ Present & 0.04 \\
\hline
\end{tabular}

\section{Cover Changes by Maximum Inundation/Duration of Inundation}

In addition to the overall response of a given species to the new water management

regime at SBW, I looked at the response of the species in relation to maximum

inundation/duration of inundation. Table 15 shows the maximum inundation and the

duration of inundation for the range of elevations along transects. 
Table 15: Elevation, Depth, and Duration in 2009.

This table shows the relationship between transect elevation, maximum inundation, and duration of inundation for the 2008/2009 water year. It can be referenced for Figure 16 and Figure 17.

\begin{tabular}{|c|r|r|}
\hline $\begin{array}{c}\text { Transect } \\
\text { Elevation (m) }\end{array}$ & $\begin{array}{c}\text { Maximum } \\
\text { Inundation, } \\
\mathbf{2 0 0 9}(\mathbf{m})\end{array}$ & $\begin{array}{c}\text { Duration of } \\
\text { Inundation, } \\
\mathbf{2 0 0 9} \text { (days) }\end{array}$ \\
\hline 1.75 & 1.94 & 257 \\
\hline 2.00 & 1.69 & 250 \\
\hline 2.10 & 1.59 & 241 \\
\hline 2.25 & 1.44 & 223 \\
\hline 2.50 & 1.19 & 204 \\
\hline 2.75 & 0.94 & 194 \\
\hline 3.00 & 0.69 & 183 \\
\hline 3.25 & 0.44 & 166 \\
\hline 3.50 & 0.19 & 140 \\
\hline 3.75 & 0 & 0 \\
\hline 4.00 & 0 & 0 \\
\hline
\end{tabular}

The vegetation at SBW responded differently to the water management based on the particular species examined and the maximum depth or duration of flooding. Figure 16 shows the changes in vegetation distribution based on transect elevation, and thus depth and duration of flooding. In some cases, as with Polygonum, Carex, and Fraxinus latifolia, there was an overall increase in distribution. In other cases, as with Phalaris, Salix, Ludwigia, and Bidens, there was a shift in distribution based on elevation or a different response at different elevations. 


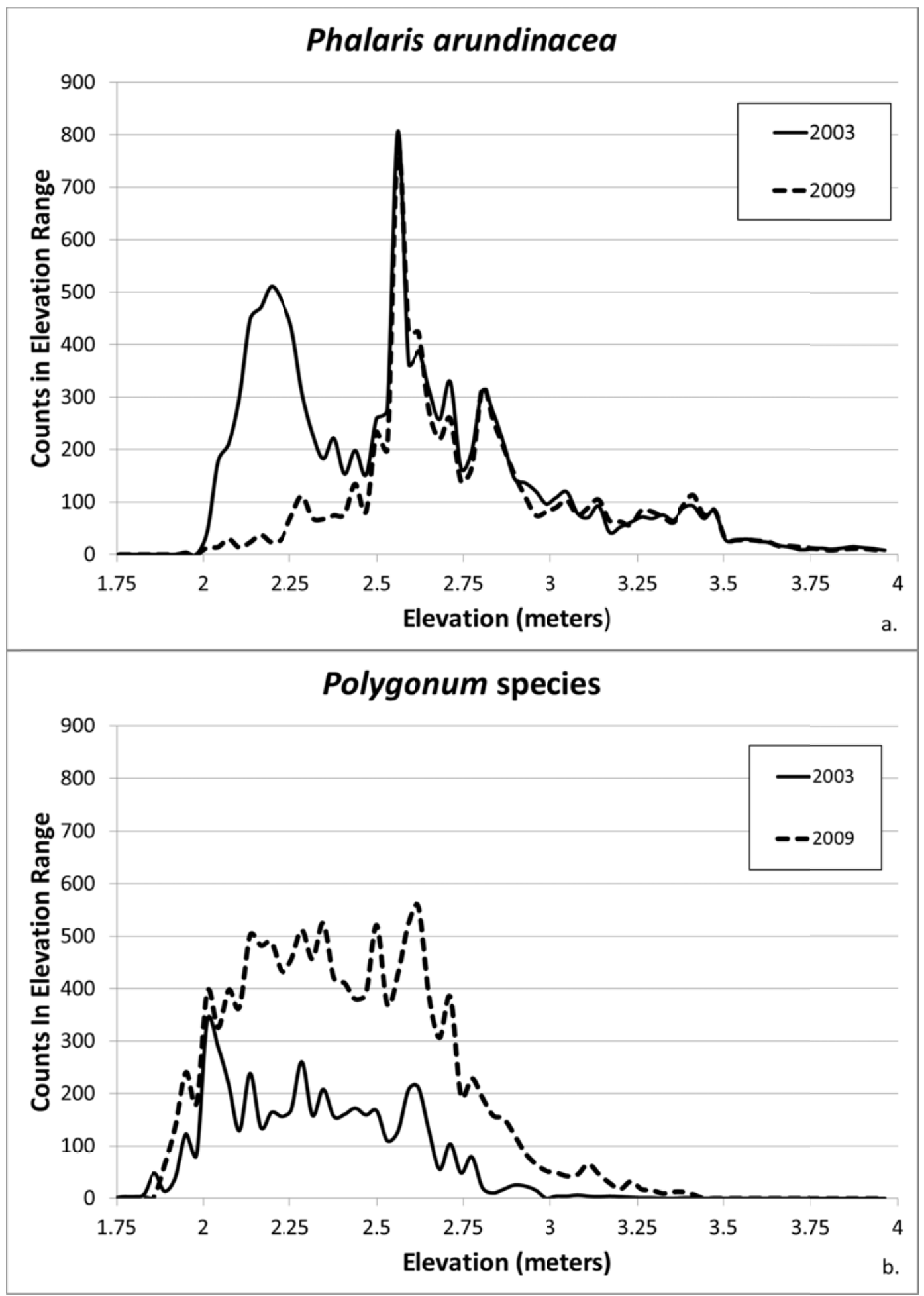




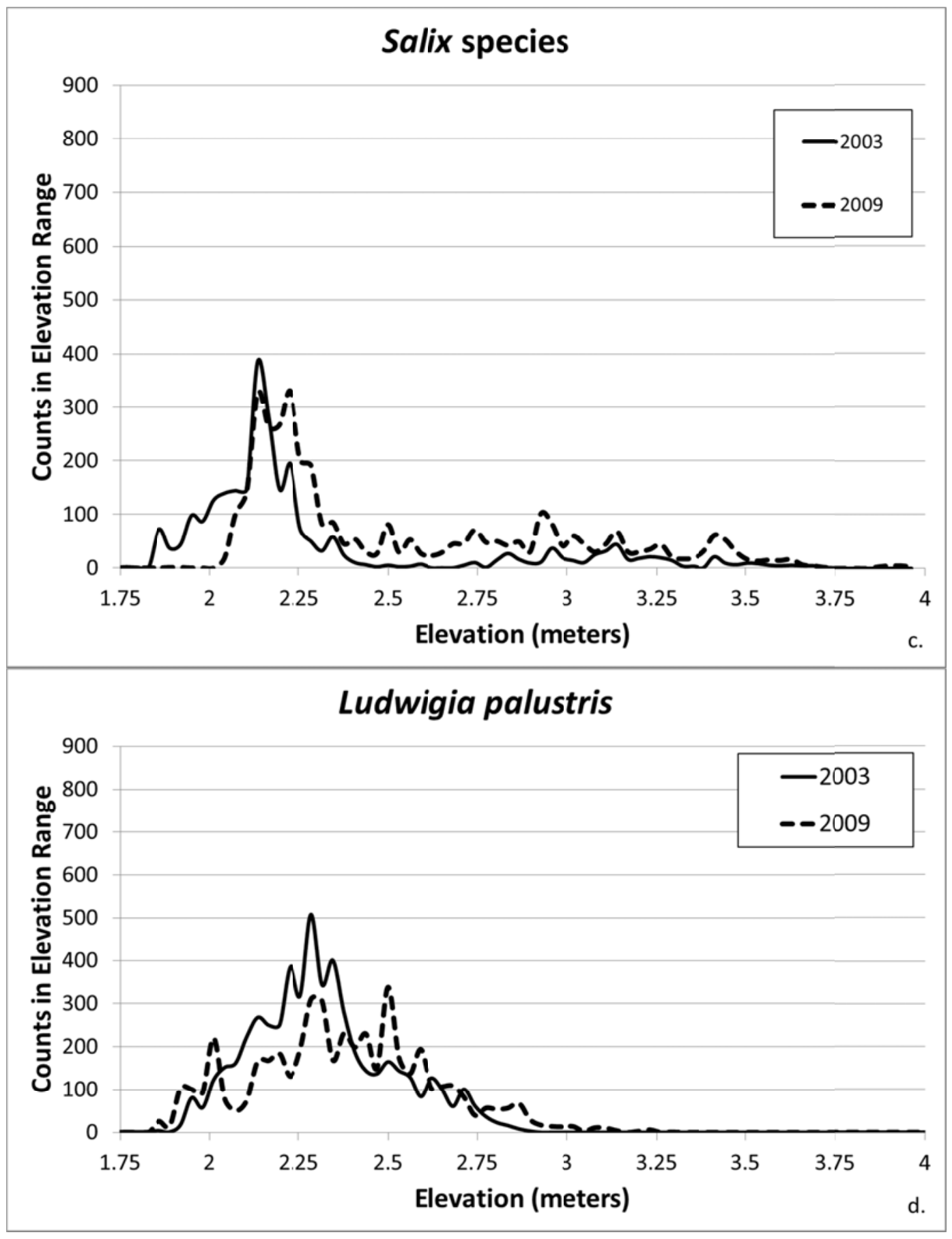




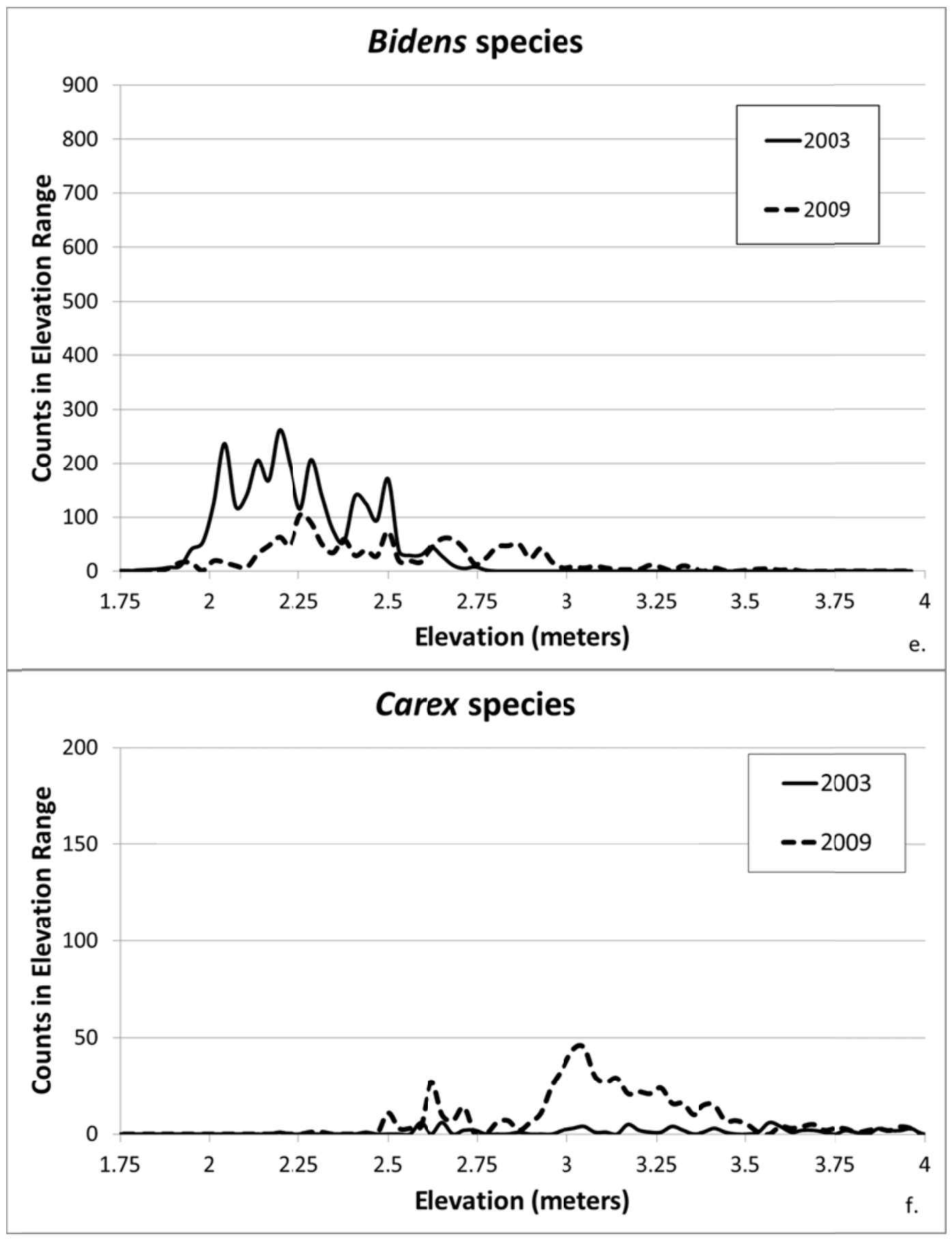




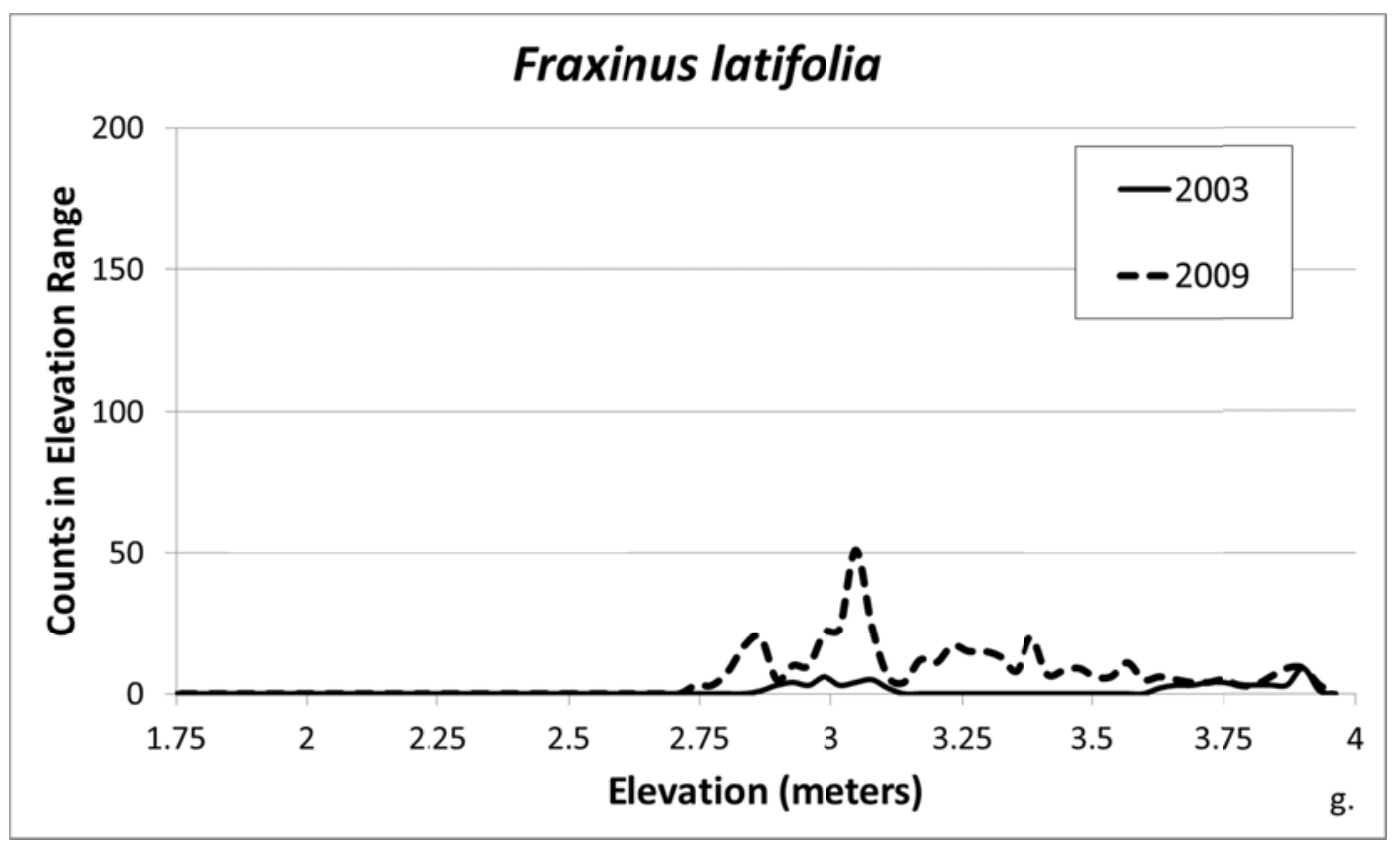

Figure 16 a.-g.: Elevation-Based Vegetation Profiles in 2003 and 2009.

Shown are the histograms of the counts within transect elevation ranges for important species in 2003 and 2009. Elevation ranges are divided into 0.03 meter intervals. The $x$-axis is the transect elevation; the $y$-axis is the number of counts in the 0.03 meter interval elevation range. Figure $16 \mathrm{f}$. and g. use a different scale due to the small number of counts overall. Table 15 may be referenced for the corresponding maximum inundation and duration of inundation.

The results of the McNemar and heterogeneity testing for the overall population (Table 16) showed that several differences in vegetation response based on transect elevation were significant. Below 3.1 meters elevation Phalaris was more likely to decline in cover, while above 3.1 meters it was more likely to increase in cover. Salix was more likely to decline below 2.1 meters elevation but more likely to increase in cover above 2.1 meters. Although Bidens decreased in overall cover, when only the population above 2.5 meters elevation was examined, Bidens was more likely to increase in cover. Similarly, Ludwigia decreased in overall cover, but above 2.4 meters elevation was more likely to increase in cover. The differences between Smith and Bybee lakes are available in Appendix B. 
Table 16: Elevation-Based Cover Change Significance.

This table shows the significance of cover changes of major species based on elevation/maximum inundation/duration of flooding. The population of each species was split based on an apparent difference in response above and below a certain elevation. The elevation split was observed in the field and on the elevation profiles in Figure 16. The McNemar chi-squared test was used to determine significance.

\begin{tabular}{|c|c|c|c|c|c|c|c|}
\hline \multirow[b]{2}{*}{ Species } & \multirow[b]{2}{*}{$\begin{array}{l}\text { Elevation } \\
\text { Split }\end{array}$} & \multicolumn{2}{|c|}{2008} & \multicolumn{2}{|c|}{2009} & 2008 & 2009 \\
\hline & & $\chi^{2}$ & p-value & $\chi^{2}$ & p-value & \multicolumn{2}{|c|}{$\begin{array}{c}\text { Direction of } \\
\text { Change }\end{array}$} \\
\hline Polygonum & above 2.0 & 6172.4 & $<0.001$ & 6088.2 & $<0.001$ & $\uparrow$ & $\uparrow$ \\
\hline Polygonum & below 2.0 & 353.1 & $<0.001$ & 124.0 & $<0.001$ & $\uparrow$ & $\uparrow$ \\
\hline Phalaris & above 2.5 & 21.3 & $<0.001$ & 36.2 & $<0.001$ & $\downarrow$ & $\downarrow$ \\
\hline Phalaris & below 2.5 & 3657.4 & $<0.001$ & 3396.8 & $<0.001$ & $\downarrow$ & $\downarrow$ \\
\hline Phalaris & above 3.1 & 28.1 & $<0.001$ & 21.9 & $<0.001$ & $\uparrow$ & $\begin{array}{c}\uparrow \\
\end{array}$ \\
\hline Phalaris & below 3.1 & 2953.9 & $<0.001$ & 2819.4 & $<0.001$ & $\downarrow$ & $\downarrow$ \\
\hline Salix & above 2.1 & 1919.2 & $<0.001$ & 1312.0 & $<0.001$ & $\uparrow$ & $\uparrow$ \\
\hline Salix & below 2.1 & 107.9 & $<0.001$ & 425.8 & $<0.001$ & $\downarrow$ & $\downarrow$ \\
\hline Bidens & above 2.5 & 502.4 & $<0.001$ & 284.3 & $<0.001$ & $\uparrow$ & $\bar{\uparrow}$ \\
\hline Bidens & below 2.5 & 1024.9 & $<0.001$ & 1267.3 & $<0.001$ & $\downarrow$ & $\downarrow$ \\
\hline Carex & above 3.6 & 0.6 & Not sig. & 6.2 & $<0.05$ & $\uparrow$ & $\uparrow$ \\
\hline Carex & below 3.6 & 455.9 & $<0.001$ & 410.9 & $<0.001$ & $\uparrow$ & $\uparrow$ \\
\hline Ludwigia & above 2.4 & 195.0 & $<0.001$ & 146.8 & $<0.001$ & $\uparrow$ & $\uparrow$ \\
\hline Ludwigia & below 2.4 & 1024.1 & $<0.001$ & 264.9 & $<0.001$ & $\downarrow$ & $\downarrow$ \\
\hline
\end{tabular}

In many cases, the relationship between Phalaris response and other species responses was notable (Figure 17). Particularly, the negative response of Phalaris was opposite the positive response of Polygonum in lower transect elevations. Similarly, the positive response of Salix, except in the lowest transect elevations, was opposite the negative Phalaris response. Ludwigia palustris, Bidens, and Veronica each showed an increase in cover in some of the lower transect elevations where Phalaris declined. Polygonum, Salix, Ludwigia palustris, and Carex all increased in cover in some transect elevations where Phalaris also increased in cover. Figure 17 shows the change from 2003 to 2009 in several important species graphed against the change in Phalaris for the same time period. This figure differs from Figure 8 in that only change, not the original 
distribution of the species, is shown. Maximum inundation in 2009 is the elevation-based increment used in the figure, but it is interchangeable with transect elevation and duration of inundation in 2009 (refer to Table 15). 

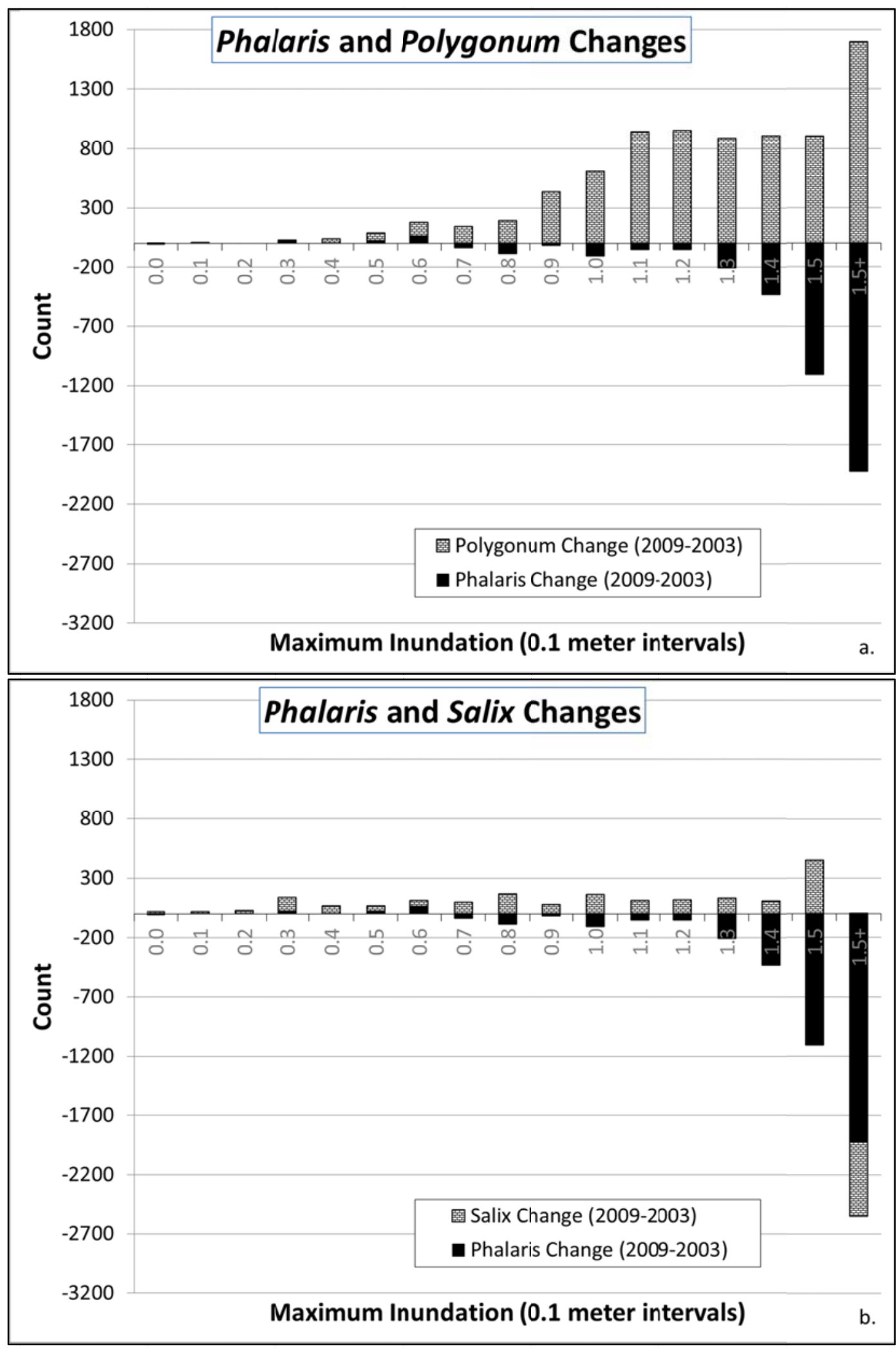

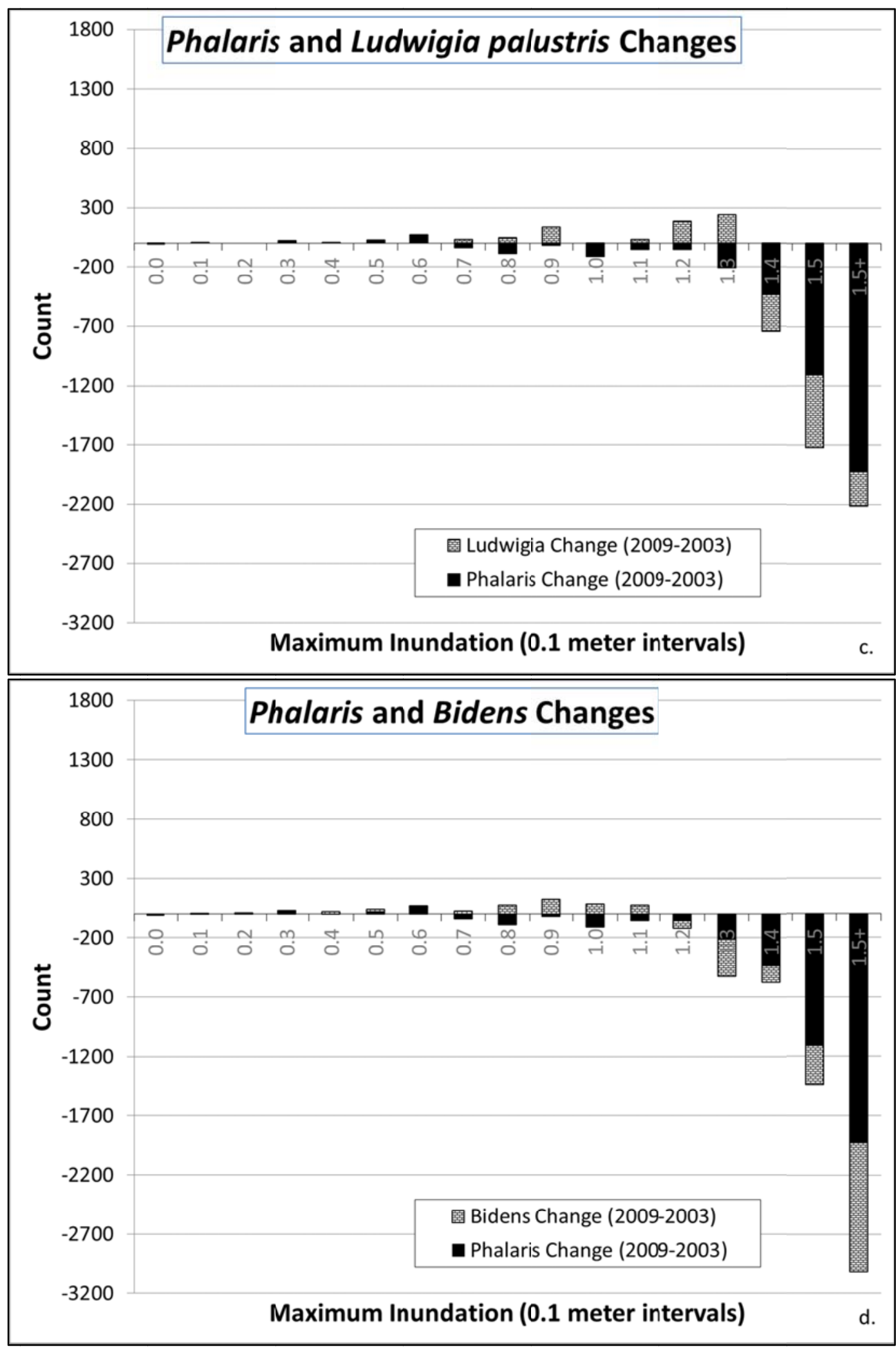

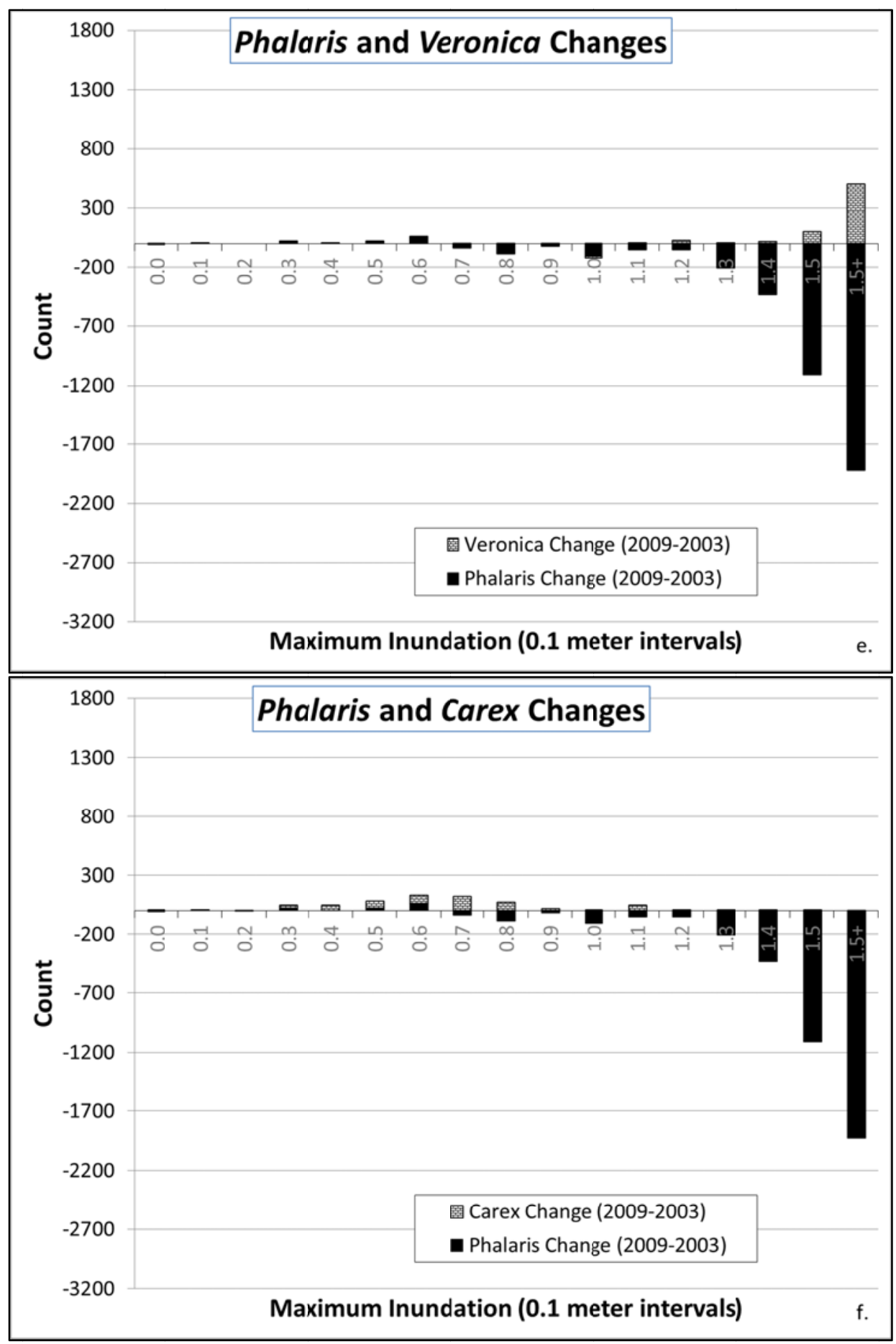

Figure 17: Stacked Graphs of Cover Changes Based on Maximum Inundation.

The cover changes are based on count changes in the maximum inundation interval ( 0.10 meter intervals) from 2003 to 2009. Each species is graphed with Phalaris change during the same time period in the corresponding maximum inundation intervals. The maximum inundation intervals are based on 2009 hydrology, with the deeper end of the inundation interval shown (e.g. ' $0.7 \mathrm{~m}$ ' is the interval from $0.6 \mathrm{~m}$ to $0.7 \mathrm{~m}$ of maximum inundation). 


\section{Chapter 4: Discussion and Conclusions}

\section{Hydrology}

The WCS was, on average, able to change the hydrology of SBW to more closely resemble the historic pattern of spring flooding and summer drying. Inter-annual variations in precipitation and Columbia River dam releases will likely continue to cause irregular annual hydrology at SBW. However, these variations do not diminish the overall hydrology trend. The restoration of hydrology and/or reconnection to the surrounding watershed is vitally important to the restoration of bottomland wetland functions (Hunter et al. 2008). Based on the hydrology achieved at SBW in the years following installation of the WCS, improvement was observed in all the following factors: the wetland functions of water storage and delay, sediment stabilization and phosphorus retention, resident and anadromous fish habitat support, amphibian and turtle habitat, breeding waterbird support, wintering and migrating waterbird support, and support of characteristic vegetation (Adamus et al. 2001).

Only half of SBW was managed completely as intended. Bybee Lake had a direct connection to the WCS and could therefore be drawn down and flooded as prescribed. Smith Lake was indirectly connected to the WCS. Separating Smith Lake from the WCS were an inter-lakes channel and Bybee Lake. Beaver activity in the channel resulted in the partial impoundment of Smith Lake. Vegetation data from Smith Lake could only be correlated to the overall SBW hydrology down to the elevation of the top of the beaver dam. Below that elevation, hydrology in Smith Lake was undetermined, affected primarily by evapotranspiration. Beaver were a historic part of the hydrology of the area 
(Christy 2004). They played an important role in the dynamic system of sloughs, wetlands, lakes, and backwaters that filled the Columbia River bottomlands. However, their activity during the study made it difficult to correlate hydrology to vegetation data in Smith Lake. Future studies should monitor hydrology in addition to vegetation in Smith Lake to more closely examine the relationship between vegetation response and hydrology there. This could be implemented with a pressure transducer and/or a permanent staff gauge. It should be noted that we did install such a meter near the beaver dam, but it failed due to corrosion of the transducer.

\section{Phalaris arundinacea Response to Water Management}

This study showed that within 5 years of annual water management, Phalaris cover was reduced in areas with 0.6 meters or more of maximum inundation. This finding was important in that it refined the magnitude of water management recommended by Jenkins et al. (2008) to successfully reduce Phalaris cover from 0.85 meters or more of maximum inundation to 0.6 meters. This means that within the same site, a much greater area should experience reduced Phalaris cover after several years than previously thought with only one year of data. The 0.6 meter maximum inundation corresponded to a transect elevation of approximately 3.1 meters (NGVD 29) and a duration of approximately 180 days under water. Since initiation of water management, water usually reached its maximum level around March, with water held within SBW between December and June. This flooding period allowed inundation of Phalaris during the cool season growth period. 
Areas with the deepest maximum inundation showed the most dramatic reductions in Phalaris. In these areas, Phalaris often either was replaced by a single species of Polygonum or by unvegetated areas (either open water or mudflat with sparse, immature vegetation). These alternative cover types are preferred from a management perspective because they provide valuable habitat elements for native species. For example, Polygonum provides winter forage for water birds, open water provides increased water storage and delay, and mudflats provide an excellent source of habitat for migrating shore birds.

Areas that experienced less than 0.6 meters of inundation showed a small but significant increase in Phalaris cover. Previously there was concern that the changed water regime might allow for an advance of the Phalaris zone further upland around SBW. The results of this study, however, do not indicate that this should be a major concern.

Inadequately flooded areas are vulnerable to invasion and Phalaris in these areas is stimulated to make morphological adaptations which further increase its invasiveness (Kercher and Zedler 2004). Several studies have shown that when Phalaris is flooded the shoot:root ratio increases (Lefor 1987, Coops and van der Velde 1995, Coops et al. 1996, and Miller and Zedler 2003), giving it a competitive edge over less adaptable species once water recedes and normal growth can resume. It is unclear if, in areas with less than 0.6 meters of flooding, a decrease in root allocation was still weakening the plant or if the Phalaris population was stable in relation to water affects. As the root reserves are slowly depleted in these areas with less than 0.6 meters inundation, Phalaris 
may experience a greater decline up to a threshold minimum depth that has yet to be determined.

The reduction of Phalaris in areas with greater than 0.6 meters of maximum inundation was also significant in that it contributed to the sparse body of literature pertaining to water management of Phalaris. Besides the Jenkins et al. (2008) study, only a few researchers have documented specific water depths or durations which show a reduced Phalaris cover. Also, there are even fewer results based on field experiments. Lefor (1987), Coops et al. (1996), and Antieau (2003) reported reduced cover with $30 \mathrm{~cm}$ of water. The Lefor (1987) and Antieau (2003) studies were in field settings, however the former was an observational study and the latter was a Washington State Department of Transportation report that was not subjected to the peer-review process. Coops and van der Velde (1995) showed that Phalaris seedlings stopped growth when submerged under $10 \mathrm{~cm}$ of water. Cooke (1997) asserted that Phalaris declines under prolonged flooding through a growing season. Paveglio and Kilbride (2000) reported on a field experiment that found that a depth of $50 \mathrm{~cm}$, held through the winter and early spring, over three years was enough to almost completely eliminate Phalaris. However, the Paveglio and Kilbride (2000) methods included other Phalaris management activities including disking and herbicide application. Stannard and Crowley (2001) claimed that with continual inundation the roots of Phalaris will eventually die. In pot studies, Miller and Zedler (2003) found that the group with the longest flooding (20 weeks with $15 \mathrm{~cm}$ of water) had the lowest biomass when compared to the groups with saturation only, low water, or cyclic flooding. However, Phalaris under the flooded conditions was still productive when compared to other species. 
Overall Phalaris cover decreased dramatically between 2003 and the years of this study, 2008 and 2009. Cover decreased by over one-third from 2003 to 2009. Though significant, Jenkins et al. (2008) noted only a modest 2.1 percent cover decrease in 2004, the first year after water management began at SBW. Jenkins et al. (2008) also examined the phenological response of Phalaris subjected to deeper inundation. They found that Phalaris exposed to deeper mid-season inundation had reduced erectness in late season growth. Although Phalaris was still present in these areas in 2004, the reduced vigor foreshadowed the results of this study and suggested that Phalaris would continue to decrease in cover the longer it was exposed to the new water management regime. The Tanner et al. (2002) study also demonstrates that the longer water management is employed, the greater the reduction in cover. Future data collection will reveal if Phalaris continues to decline overall, or if it has reached a steady state with only slight inter-annual variation due to differences in annual hydrology.

The response of Phalaris to the new water management regime when Salix was present was much more pronounced than the response of Phalaris overall. As in the Jenkins et al. (2008) study, I found that Phalaris cover within Salix stands was lower than Phalaris cover overall. In addition, I found that the reduction in Phalaris cover was much greater within Salix stands than it was outside of Salix stands as in the Jenkins et al. (2008) study. If Phalaris is pushed upland, it would be interesting to look at areas where shading from woody species other than Salix may prevent or reduce its establishment. Populus balsamifera in particular may do this as it forms large stands in upland location under which there is much reduced light penetration. 


\begin{abstract}
Abundance
The most notable change in abundance following the initiation of water management at SBW was that Polygonum replaced Phalaris as the dominant species. This primarily occurred in the lowest/wettest sampled locations, to which Polygonum species (especially P. amphibium) are particularly suited (Mitchell 1976, Carter and Grace 1990, Partridge 2001). By 2008, Polygonum occupied even more area than Phalaris had prior to the new water regime of deeper and longer duration inundation. Barnes (1999) found that with fewer flooded days, Phalaris replaced a Polygonum species. In restored prairie pothole wetlands (Mulhouse and Galatowitsch 2003), Polygonum distribution after 12 years was similar to that of SBW. It was located between open water, dominated by floating aquatic species, and wet meadows, dominated by Phalaris and other species less tolerant of flooding.
\end{abstract}

The abundance response of Salix was also notable. It increased in cover overall, but shifted to slightly higher elevations that experience less depth and duration of inundation. Below 2 meters transect elevation, Salix virtually disappeared. The peak of the Salix population is now between 2.1 meters and 2.3 meters of transect elevation. This elevation range experiences approximately 1.4 meters to 1.7 meters of maximum inundation and approximately 215 to 250 days of inundation. Timoney and Argus (2006) found a similar Salix response in the Peace-Athabasca Delta. Salix there responded to decade-scale water conditions, dying back in areas that were flooded for extended periods and going through establishment phases in areas that were drier. Keddy and Fraser (2000) also noted that the duration of flooding led to vegetation zonation that pushed woody species further upland. 
The native species Bidens and Ludwigia palustris both declined in overall cover. However, these species had different responses at different elevations. For Bidens, cover dramatically declined below 2.6 meters transect elevation (approximately 200 days duration of inundation). However, above 2.6 meters elevation Bidens increased in cover. It appears that at SBW, Bidens prefers locations with at least 160 days out of water. This is slightly shorter than the life span noted in the Gratani et al. (2008) study, where researchers found that Bidens needed 200 days for life cycle completion, 100 of which were needed for the flowering and fruiting period. There are obvious climatic differences between central Italy (the Gratani site) and the Pacific Northwest, and Bidens species here may be specifically adapted to a shorter cycle. Observationally, I noted that the majority of the Bidens individuals encountered on transects were of short stature with very few, if any, flowers. Because of the short duration of drawdown, many Bidens individuals may not complete a full phenological cycle, and those that do may be producing far fewer seeds than typical for the species.

For Ludwigia palsutris, cover declined somewhat between 2 meter and 2.4 meters of transect elevation but increased above and below this elevation. Its distribution is more evenly distributed between 1.9 meters and 2.8 meters of transect elevation than it was prior to water management when the more pronounced peak was between 2.1 meters and 2.4 meters elevation. Guard (1995) noted that the species is able to tolerate a wide variety of water levels, but little other information is available pertaining to the response of this species to flooding. At SBW, Ludwigia was one of the few species able to coexist under the dense stands of Polygonum, and often dominated gaps in the dense Polygonum cover. 
Carex species and Fraxinus latifolia are two locally rare species that experienced considerable increases in cover at SBW. In the case of Carex (Carex aperta), this was especially significant because the species is currently so rare in the Columbia River bottomlands. In restored locations where an invasive species had dominated, Hall and Zedler (2010) noted that increases in Carex resulted only from vegetative spread. They found that in these areas, the Carex seed bank had been depleted and that active seeding and/or replanting was necessary for the species to recover. Although this may be true at SBW, in locations where Carex was absent prior to management the species showed a 7fold increase in cover overall. Carex was present on nineteen of the twenty-six transects, and on nine of these nineteen transects it appeared only after water management began.

Fraxinus latifolia is an important component of the Columbia River bottomland community, so the 6-fold increase it made at SBW is significant for the region. It is the dominant species in late successional riparian forests along the Willamette River according to Fierke and Kauffman (2006). They found that Phalaris inhibited the growth of Fraxinus latifolia in the understory, interfering with the successional process. SBW managers have noted a lack of understory recruitment of tree species in other portions of the site (Elaine Stewart, personal communication). Based on the results of vegetation data analysis, it appears that Fraxinus latifolia cover and other native woody species are increasing in the understory.

Some native species appeared for the first time on transects following initiation of water management. However, the general trend at SBW following initiation of water management was a decline in overall species richness and abundance. Far fewer species increased in overall cover than decreased. Further, only a few species appeared for the 
first time on the transects compared to the number of species that completely or nearly disappeared from the transects after water management began. This fits with other research indicating that passive restoration, without seeding, planting, or other management activities may not be adequate to restore the full range of species found in natural systems (Galatowitsch and van der Valk 1996, Mulhouse and Galatowitsch 2003, Nedland et al. 2007, Gerard et al. 2008a, Gerard et al. 2008b, and Hall and Zedler 2010). The few species that did increase in overall cover were almost entirely perennial or woody species, another aspect shared by other wetland restoration studies (Galatowitsch and van der Valk 1996, Mulhouse and Galatowitsch 2003, and Nedland et al. 2007). Lythrum salicaria, Iris pseudacorus, and Myriophyllum aquaticum are three invasive species found at SBW in relatively low abundance. However, as these species are extremely noxious and found extensively in the surrounding areas, their populations should be monitored closely. L. salicaria cover increased 5-fold during this study. Schooler et al. (2006) found an inverse relationship between Phalaris and L. salicaria at sites where Phalaris was abundant, $L$. salicaria was not, at sites where $L$. salicaria was abundant Phalaris was not. Based on the results of their research they strongly suggest that management of both species simultaneously is needed to avoid an infestation of one of the species while trying to control the other. Cover of M. aquaticum increased dramatically in Smith, indicating that the new water regime, or the water regime in Smith resulting from beaver activity, may benefit this species. The species virtually disappeared from Bybee, however this is likely due to herbicide treatment. Only Bybee was treated with herbicide because only this portion of SBW completely drained, facilitating application. I. pseudacorus was not present in any locations along the transects during 
baseline vegetation data collection. By 2009, cover was 0.3 percent. While still low in overall cover, its aggressive growth should be monitored while the invasion is still minor.

\section{Response to Depth vs. Duration}

In this thesis, I reported results as a response to depth of inundation or duration of inundation interchangeably. In fact, I found that maximum inundation had a linear relationship with the duration of inundation. Deep maximum inundation at SBW is highly correlated with a long duration of inundation. I was not able to conclude that one or the other is the more critical in vegetation response or if they both are needed to achieve the results. This was largely because of the difficulty in discerning to which factor or factors correlated to depth or duration the vegetation responded. In pot or greenhouse studies, it is theoretically easier to distinguish the effects of the depth of inundation and the duration of inundation. Variables associated with depth or duration that could influence vegetation response including local turbidity, light penetration, substrate, currents, interspecific competition responses, specific vegetation tolerances or phenological requirements, genetic variations, slope, and aspect can be more precisely controlled. In situ, however, many of these variables are nearly impossible to control. Even if all of these variables were to be monitored along with depth and duration, there are so many factors that it would be quite challenging to analyze the effects, even with multivariate analysis.

It is likely that duration of inundation may be the more critical factor for most species as very few appear able to withstand continual inundation. Most species need at least a short period without inundation to increase or maintain cover. Annual or biennial 
species such as Bidens and Epilobium that are not able to germinate early enough in the growing season due to long duration of inundation may not complete a full phenological cycle. These species experience reduced cover over the years as the seed bank is depleted. In this study and others (Keddy and Reznicek 1986, Keddy and Fraser 2000, Crawford 2003, Timoney and Argus 2006), woody species such as Salix and some herbaceous perennials demonstrate the need for at least a short period during the growing season without anoxic conditions. Salix virtually disappeared in areas without at least 120 days without flooding. Likewise, Carex only increased in cover in areas that had at least 150 days exposed.

Herbaceous perennials tolerant of flooding may respond to both depth and duration of inundation. Light penetration is one of the signals needed to initiate above ground growth for certain perennial species (Crawford 2003). With deep and long inundation, the below ground tissue of these light sensitive species may not be triggered to grow as it would with only shallow and long inundation. In this study, Polygonum was the (rooted) species most tolerant of deep and prolonged flooding. Even so, it had a lower limit to distribution based on elevation at SBW. Even when mudflats below this elevation limit were exposed, the species did not appear in large numbers. Again, it is difficult to determine if this distribution is the result of deeper inundation or a longer duration of inundation. In the case of Phalaris, deep inundation may be necessary to reduce its abundance as the species has been shown to grow and exhibit phenotypic plasticity in shallow water (Herr-Turoff and Zedler 2007, Jenkins et al. 2008). The Jenkins et al. (2008) study noted that Phalaris under deep inundation during the middle 
growing season showed decreased growth and changes in structure later in the growing season.

Possibly other factors such as the seasonal timing of maximum inundation or the specific months during the growing season that experience inundation, might also influence the abundance response of Phalaris. If deep inundation were only held for a short period in the early growing season, it would likely not be effective to reduce the cover of Phalaris. Without greenhouse studies or varying water management regimes and resulting vegetation analysis, I am not able to conclude that it was depth, duration, timing of flooding, or some combination of the three that produced the results of this study.

\section{Diversity}

Diversity declined since initiation of water management at SBW. One reason that diversity did not increase is that in the wetter portions of SBW Phalaris, the major dominant species that formed monotypic stands prior to the study, was replaced by Polygonum, an obligate wetland species that also forms dense, monotypic stands. There was a strong negative association between the density and abundance of Phalaris and plant diversity as shown in other studies (Green and Galatowitsch 2002, Werner and Zedler 2002, Houlahan and Findlay 2004, Kercher and Zedler 2004, Schooler et al. 2006, and Jenkins et al. 2008). Project data revealed this negative correlation between Phalaris cover and diversity in 2003 and 2004. However, by 2008 and 2009 there was no longer a negative correlation because the abundance and density of the species had decreased so dramatically. Instead, the 2008 and 2009 vegetation data showed a negative correlation 
between Polygonum cover and diversity where there was no correlation in 2003 and 2004. Project data showed that one extremely dominant/monotypic species was replaced by another (Phalaris by Polygonum) and that as cover of a single competitive species increased, diversity decreased. In particular, when the largest stands of either Phalaris or Polygonum (comprising $80 \%$ or more of the cover for the transect) were removed from the correlation analysis, there was no longer a negative relationship between diversity and cover. The large monotypic stands of these species were driving down the measure of diversity for the site. Houlahan and Findlay (2004) also found that stand-forming, highly competitive species such as Phalaris threatened diversity, but that this type of species could be exotic or native. This result suggests that if increased diversity is a desired outcome, one must consider controlling all species that competitively exclude other species.

Another reason diversity did not increase is that areas that are inundated for long periods tend to be dominated by one or two dominant species (van der Valk et al. 1994, Nielsen and Chick 1997, Barrett et al 2010). As previously discussed, monotypic stands of the obligate wetland species Polygonum replaced the facultative wetland species Phalaris in the wettest portions of SBW. In addition, several other species that were present in wettest parts of SBW including Salix, Ludwigia, and Bidens either declined in abundance (Ludwigia and Bidens) and/or shifted to slightly drier locations (Salix, Ludwigia, and Bidens). Tanner et al (2002) noted a loss in forest cover following hydrological restoration; however, they reported an increase in diversity several years following restoration. 
SBW experienced both increased hydrology and increases in sedimentation, both of which could affect diversity. In the wettest areas the number of emergent/ephemeral species declines and there are few opportunities for species recruitment (Nielsen and Chick 1997, Bornette et al 1998, and Brock et al. 2005). There is a resultant reduced abundance and diversity of species (Bornette et al 1998 and Casanova and Brock 2000). The species that do thrive in these zones are those which spread through vegetative growth. Polygonum, the dominant species in this zone at SBW, is a species which has been noted to spread almost exclusively through vegetative means, often forming large stands generated from a single clone (Carter and Grace 1990, Partridge 2001). Peterson and Baldwin suggest (2004) suggest that increased hydrology and sedimentation may be responsible for the loss of seed bank species expression. As little as 3-10 cm of flooding in the spring has been shown to reduce the diversity and abundance of annual species (Baldwin et al. 2001). Jurik et al. (1994) reported that as little as $0.25 \mathrm{~cm}$ deep reduced the number of species and the number of individuals expressed from a seed bank sample. Aronson and Galatowitsch (2008) found that restored prairie pothole wetlands increased in diversity and species richness in the first 12 years following establishment. During this phase, the rate of increase was approximately 14 species per year. After the establishment phase, species declined at a rate of approximately 1.5 species per year. However, during the establishment phase the most efficient guilds (including introduced/invasive perennials, submersed and floating aquatics, and emergent perennial in this study) established much more rapidly than less efficient guilds (including wet prairie, sedge meadow, and woody species). Diversity appeared to follow a similar pattern at SBW, though the establishment phase was much reduced. An initial increase in 
diversity compared to baseline vegetation data was noted by the Jenkins et al. (2008) study based on year 1 vegetation data. The results reported in this thesis, based on year 5 and year 6 vegetation data, showed a decrease in diversity below the levels prior to water management and a small, but significant, increase in sedge meadow and woody species. Future data collection should focus on these "inefficient" communities of sedge meadow and woody species to determine if the new water management ultimately benefits them.

An increase in diversity was a possible outcome as hydrology restoration has been theorized to maximize the diversity of a community adapted to a specific level of disturbance (Denslow 1985). However, even when monotypic stands were removed from the overall diversity analysis, diversity did not increase in 2008 or 2009. Initially, diversity appeared to be increasing as seen in diversity measures from 2004. However, in later years (2008 and 2009) diversity decreased to levels below those prior to managed flooding. Future study of diversity trends at SBW is warranted.

\section{Conclusions/Management Implications}

Phalaris was shown to be effectively controlled with flooding alone, provided that the depth and duration of flooding were adequate. However, in locations that were not flooded for enough time or with deep enough water, Phalaris slightly increased in abundance. Knowing this, natural area managers could couple flood control with selected plantings and other methods of control such as early season mowing or herbicide application in areas that will not be subjected to adequate flooding. Polygonum, especially Polygonum amphibium, and Salix are ideal candidates for selected plantings as both were shown to be highly competitive with Phalaris. 
Diversity decreased following flood control of Phalaris without active management of desired natives. Bare ground and open water increased dramatically, especially in lower elevations subject to greater depth and longer duration of flooding. In these areas, a single or a few perennial species increased in abundance. These species were exclusively obligate wetland species with a tendency towards vegetative reproduction through clonal growth. Ecologically desirable species intolerant of deep and long duration of inundation that reproduce primarily through seeds were reduced in cover in these lower elevations. Annual, facultative wetland species were largely pushed out by the more aggressive obligate perennials. In low elevation areas where they were present, they were extremely small in stature and may not have had the opportunity to set seed. To both increase diversity and the abundance these species, SBW managers may wish to hold water in the site for less duration. If the drawdown were initiated around the same time in early summer but completed more quickly, more of these ephemeral species could complete a full phenological cycle, providing a more substantial seed bank for the next growing season. In areas with the appropriate hydrology, these species were shown to increase in cover at SBW. However, active management such as further water management modification, seeding, and planting may be necessary to assure that the species do not continue to decline overall or to decline below a level that can withstand severe annual variations in hydrology. 


\section{References}

Adams, Carrie Reinhardt and Susan M. Galatowitsch. 2005. Phalaris arundinacea (reed canary grass): rapid growth and growth pattern in conditions approximating newly restored wetlands. Ecoscience 12(4): 569-573.

Adams, Carrie Reinhardt and Susan M. Galatowitsch. 2006. Increasing the effectiveness of reed canary grass (Phalaris arundinacea L.) control in wet meadow restorations. Restoration Ecology, Vol 14, Issue 3, pp. 441-451.

Antieau, C.J. 2003. Biology and management of reed canarygrass, and implications for ecological restoration. Washington State Department of Transportation, Seattle, WA.

Aronson, Myla F J and Susan Galatowitsch. 2008. Long-Term Vegetation Development of restored prairie pothole wetlands. Wetlands Vol 28, No 4, pp. 883-895.

Baldwin, Andrew H, Michael S Egnotovich, and Ernest Clarke. 2001. Hydrologic change and vegetation of tidal freshwater marshes: field, greenhouse, and seed-bank experiments. Wetlands Vol 21 no 4, pp. 519-531.

Barclay, A.M. and R.M.M. Crawford. 1982. Plant growth and survival under strict anaerobiosis. Journal of Experimental Botany Vol 33 No 134 pp. 541-549.

Barnes W J. 1999. The rapid growth of a population of reed canarygrass (Phalaris arundinacea) and its impact on some riverbottom herbs. J Torrey Botanical Society 126: 133-138.

Barrett, Rose, Daryl L. Nielsen, and Roger Croome. 2010. Associations between the plant communities of floodplain wetlands, water regime and wetland type. River Research and Applications. 26:866-876 (2010).

Bayley, P.B. 1995. Understanding large river-floodplain ecosystems. BioScience 45:153-158.

Blossey, Bernd. 1999. Before, during and after: the need for long-term monitoring in invasive plant species management. Biological Invasions 1:301-311.

Bornette G, C Amoros, and N Lamouroux. 1998. Aquatic plant diversity in riverine wetlands: the role of connectivity. Freshwater Biology 39: 267-283. 
Brandel, Markus. 2004. The role of temperature in the regulation of dormancy and germination of two related summer-annual mudflat species. Aquatic botany 79 (2004) 15-32.

Brock, MA, DL Nielsen, and K Crossle. 2005. Changes in biotic communities developing from freshwater wetland sediments under experimental salinity and water regimes. Freshwater Biology 50:1376-1390.

Buijse, A D, H. Coops, M. Staras, L. H. Jans, G. J. van Geest, R. E. Grift, B. W. Ibelings, W. Oosterberg, and F. C. J. M. Roozen. 2002. Restoration strategies for river floodplains along large lowland rivers in Europe. Freshwater Biology 47, 889-907.

Carlson, I T, R N Oram, and J Surprenant. 1996. Reed canarygrass and other Phalaris species. Agron Monograph 34: 569-604.

Carter, Mark F. and James B. Grace. 1990. Relationships between flooding tolerance, life history, and short-term competitive performance in three species of Polygonum. American Journal of Botany 77(3): 381-387.

Casanova, Michelle T and Margaret A Brock. 2000. How do depth, duration and frequency of flooding influence the establishment of wetland plant communities. Plant Ecology 147:237-250.

Christy, John A. 2004. Native freshwater wetland plant associations of northwestern Oregon. Oregon Natural Heritage Information Center, Oregon State University.

Cooke, S. S. 1997. A Field Guide to the Common Wetland Plants of Western Washington and Northwestern Oregon. Seattle Audubon Society, Seattle, WA.

Coops, Hugo and Gerard van der Velde. 1995. Seed dispersal, germination and seedling growth of six helophyte species in relation to water-level zonation. Freshwater Biology 34, 13-20.

Coops, H., F. W. B. van den Brink, and G. van der Velde. 1996. Growth and morphological responses of four helophyte species in an experimental water-depth gradient. Aquatic Botany 54:11-24.

Crawford, R.M.M. 2003. Seasonal differences in plant responses to flooding and anoxia. Canadian Journal of Botany 81:1224-1246.

Dahl, Thomas E. 1990. Wetlands losses in the United States 1780's to 1980's. U.S. Department of the Interior, Fish and Wildlife Service, Washington, D.C. Jamestown, ND: Northern Prairie Wildlife Research Center Online. 
http://www.npwrc.usgs.gov/resource/wetlands/wetloss/index.htm. (Version 16JUL97). Accessed March 13, 2011.

Dech, J. P. and P. Nosko. 2004. Rapid growth and early flowering in an invasive plant, purple loosestrife (Lythrum salicaria L.) during an El Nino spring. 2004. Int J Biometoerol (2004) 49:26-31.

DiTomaso, Joseph M. and Evelyn A. Healy. 2003. Aquatic and Riparian Weeds of the West. University of California Agriculture and Natural Resources, Oakland, CA.

Elzinga, C. L., D. W. Salzer, and J. W. Willoughby. 1998. Measuring and Monitoring Plant Populations. U. S. Department of the Interior, Bureau of Land Management. Denver, CO.

Environmental Protection Agency. 2009. Integrated Pest Management (IPM) Principles Webpage. Available URL: http://www.epa.gov/pesticides/factsheets/ipm.htm.

Fierke, MK and JB Kauffman. 2006. Riverscape-level patterns of riparian plant diversity along a successional gradient, Willamette River, Oregon. Plant Ecology, 185:85-95.

Fink, Daniel F and William J Mitsch. 2004. Hydrology, biogeochemistry, and plant community development in a created river diversion oxbow wetland in the Ohio River basin, USA.

Fishman Environmental Services, Ogden Beeman and Associates, Inc., Shannon and Wilson, Inc., Scientific Resources, Inc., Philip K. Gaddis. 1987. Smith and Bybee Lakes Environmental Studies Technical Appendicies.

Fraser, Lauchlan H and Jason P Karnezis. 2005. A comparative assessment of seedling survival and biomass accumulation for 14 wetland plant species grown under minor water-depth differences. Wetlands Vol 25 No 3 Sept 2005 pp. 520-530.

Galatowitsch, Susan M and Arnold G van der Valk. 1996. The vegetation of restored and natural prairie wetlands. Ecological Applications 6(1) pp. 102-112.

Galatowitsch, Susan M., Neil O. Anderson, and Peter D. Ascher. 1999. Invasiveness in wetland plants in temperate North America. Wetlands, Vol 19, No 4, Dec 1999, pp. 733755 .

Gerard, Marian, Mohssine El Kahloun, Joke Rymen, Oliver Beauchard, and Patrick Meire. 2008a. Importance of mowing and flood frequency in promoting species richness in restored floodplains. Journal of Applied Ecology 45 1780-1789. 
Gerard, M, M El Kahloun, W Mertens, B Verhagen, P Meire. 2008b. Impact of flooding on potential and realised grassland species richness. Plant Ecology 194:85-98.

Gratani, L., M.F. Crescente, G. Fabrini, and L. Varone. 2008. Growth pattern of Bidens cernua L.: relationships between relative growth rate and its physiological and morphological components. Photosynthetica 46 (2): 179-184.

Gratani, L., M.F. Crescente, G. Fabrini, A. Bonito, and L. Varone. 2009. Growth analysis of a reestablished population versus a natural population of Bidens cernua L. Plant Biosystems, Vol. 143, Supplement, 2009, pp. S63-68.

Green and Galatowitsch. 2002. Effects of Phalaris arundinacea and nitrate-N addition on the establishment of wetland plant communities. Journal of Applied Ecology, Vol 39, Issue 1, 134-144.

Guard, B. Jennifer. 1995. Wetland Plants of Oregon and Washington. Lone Pine Publishing, Renton, WA.

Hall, Steven J. and Joy B. Zedler. 2010. Constraints on sedge meadow self-restoration in urban wetlands. Restoration Ecology Vol 18 No 5 pp671-680.

Hanhijarvi, Anne M. and Kurt V. Fagerstedt. 1994. Comparison of the effect of natural and experimental anoxia on carbohydrate and energy metabolism in Iris pseudacorus rhizomes. Physiologia plantarum. 90:437-444.

Harris, S. W. and W. H. Marshall. 1963. Ecology of water-level manipulations on a northern marsh. Ecology 44:331-43.

Healy, Michael T and Joy B Zedler. 2010. Setbacks in replacing Phalaris arundinacea monotypes with sedge meadow vegetation. Restoration Ecology Vol 18 No 2 pp. 1551654.

Henderson, R A. 1990. Controlling reed canarygrass in a degraded oak savanna (Wisconsin). Restoration Management Notes 8: 123-124.

Henning, J. A., R. E. Gresswell, and I. A. Fleming. 2007. Use of seasonal freshwater wetlands by fishes in a temperate river floodplain. Journal of Fish Biology, Vol 71, Issue 2, pp. 476-492.

Herr-Turoff, Andrea and Joy B Zedler. 2007. Does morphological plasticity of the Phalaris arundinacea canopy increase invasiveness? Plant Ecology 193: 265-277.

Herubin, C. A. 1982. Principles of Surveying. Reston Publishing Co., Reston, VA. 
Houlahan, Jeff E and C Scott Findlay. 2004. Effect of invasive plant species on temperate wetland plant diversity. Conservation Biology, Volume 18, No 4, pp. 11321138.

Hunter, R.G., S.P. Faulkner, and K.A. Gibson. 2008. The importance of hydrology in restoration of bottomland hardwood wetland function. Wetlands 28:605-615.

Jenkins, N. J. 2005. First season effects of managed flooding on the invasive species Phalaris arundinacea $\mathrm{L}$. and shoreline vegetation communities in an urban wetland. Environmental Sciences and Resources. Portland State University. M. S. thesis. Portland, OR.

Jenkins, N.J., J.A. Yeakley, and E.M. Stewart. 2008. First-year responses to managed flooding of Lower Columbia River bottomland vegetation dominated by Phalaris arundinacea. Wetlands 28:1018-1027.

Katterer, T and O Andren. 1999. Growth dynamics of reed canarygrass (Phalaris arundinacea) and its allocation of biomass and nitrogen below-ground in a field receiving daily irrigation and fertilization. Nutrient Cycling Agroecosystems 54: 21-29.

Keddy, P. A. and T. H. Ellis. 1984. Seedling recruitment of 11 wetland plant species along a water level gradient: shared or distinct responses? Canadian Journal of Botany 63:1876-1879.

Keddy, P and Lauchlan H. Fraser. 2000. Four general principles for the mangement and conservation of wetlands in large lakes: the role of water levels, nutrients, competitive hierarchies and centrifugal organization. Lakes \& Reservoirs: Research and Management 2000 5:177-185.

Keddy, P. A. and A. A. Reznicek. 1986. Great Lakes vegetation dynamics: the role of fluctuating water levels and buried seeds. Journal of Great Lakes Research, 12(1):25-36.

Kercher, Suzanne M and Joy B Zedler. 2004a. Flood tolerance in wetland angiosperms: a comparison of invasive and noninvasive species. Aquatic Botany 80:89-102.

Kercher, Suzanne M and Joy B Zedler. 2004b. Multiple disturbances accelerate invasion of reed canary grass (Phalaris arundinacea L.) in a mesocosm study. Oecologia 138: 455-464.

Kilbride and Paveglio. 1999. Integrated pest management to control reed canary grass in seasonal wetlands of southwestern Washington. Wildlife Society Bulletin. 27: 292-297. 
Kim, KD, K Ewing, and DE Giblin. 2006. Controlling Phalaris arundinacea (reed canarygrass) with live willow stakes: A density-dependent response. Ecological Engineering Vol 27, Issue 3, pps 219-227.

Kuzovkina-Eischen, Yulia A. 2003. Stress Tolerance and Horticultural Evaluation of the Genus Salix. The Ohio State University Dissertation Degree Doctor of Philosophy in the Graduate School.

Lavergne and Molofsky. 2004. Reed canary grass (Phalaris arundinacea) as a biological model in the study of plant invasions. Critical Reviews in Plant Sciences. 23: 415-429.

Lavergne and Molofsky. 2006. Control Strategies for the invasive reed canary grass (Phalaris arundinacea) in North American Wetlands: the need for an integrated management plan. Natural Areas Journal. 26(2): 208-214.

Leck, Mary Allessio. 2003. Seed-bank vegetation development in a created tidal freshwater wetland on the Delaware River, Trenton, New Jersey, USA. Wetlands Vol 23 No 2 pp. 310-343.

Lefor, M. W. 1987. Phalaris arundinacea L. (reed canary grass - gramineae) as a hydrophyte in Essex, Connecticut, USA. Environmental Management 11:771-73.

Lesica. 1997. Spread of Phalaris arundinacea adversely impacts the endangered plant Howellia aquatilis. Great Basin Naturalist. 57: 366-368.

Leung, Brian, David M. Lodge, David Finnoff, Jason F. Shogren, Mark A. Lewis, and Gary Lamberti. 2002. An ounce of prevention or a pound of cure: bioeconomic risk analysis of invasive species. Proceedings of the Royal Society of Biological Sciences. $269,2407-2413$.

Lev, E., J. Fugate, M. P. Hayes, D. Smith, L. Wilson, and R. Wissemann. 1994. The biota of Smith and Bybee Lakes Management Area. Metro, Portland, OR.

Levine, Jonathan M., Montserrat Vila, Carla M. D. Antonio, Jeffrey S. Dukes, Karl Grigulis, and Sandra Lavorel. 2003. Mechanisms underlying the impacts of exotic plant invasions. Proceedings of the Royal Society of Biological Sciences. 270, 775-781.

Lewontin, R. C. and L. C. Birch. 1966. Hybridization as a source of variation for adaptation to new environments. Evolution, Vol 20, No 3 (Sept 1966), pp. 315-336.

Lindig-Cisneros, R and J B Zedler. 2002. Relationships between canopy complexity and germination microsites for Phalaris arundinacea. Oceologia 133: 159-1667. 
Lockwood, Julie L., Martha F. Hoopes, and Michael P. Marchetti. 2007. Invasion Ecology. Blackwell Publishing, Malden, MA. 304pp.

Los Alamos National Laboratory. 2003. Online GPS guide. URL:

http://www.gislab.lanl.gov/gps_guide.html. Last revised November 17, 2003; most recent access May 16, 2005.

Magee, Teresa K. and Mary E. Kentula. 2005. Response of wetland plant species to hydrologic conditions. Wetlands Ecology and Management 13: 163-181.

Merigliano M F and P Lesica. 1998. The native status of reed canary grass (Phalaris arundinacea) in the inland Northwest, USA. Natural Areas Journal 18:223-230.

Michener, W.K. and R.A. Haeuber. 1998. Flooding: natural and managed disturbances. BioScience 48:677-680.

Miller and Zedler. 2003. Responses of native and invasive wetland plants to hydroperiod and water depth. Plant Ecology. 167:57-69.

Mitsch, W J and R F Wilson. 1996. Improving the success of wetland creation and restoration with know-how, time, and self-design. Ecological Application 6:77-83.

Mitchell, Richard S. 1976. Submergence experiments on nine species of semi-aquatic Polygonum. American Journal of Botany 63(8): 1158-1165.

Molofsky, Morrison, and Goodnight. 1999. Genetic and environmental controls on the establishment of the invasive grass, Phalaris arundinacea. Biological Invasions. 1: 181-188.

Montague, J. L., S.C.H. Barrett, and C.G. Eckert. 2007. Re-establishment of clinal variation in flowering time among introduced populations of purple loosestrife (Lythrum salicaria, Lythraceae). Journal of Evolutionary Biology, 21, 234-245.

Moog, P. R. and P. Janiesch. 1990. Root growth and morphology of Carex species as influenced by oxygen deficiency. Functional Ecology 1990, 4, 201-208.

Moorhead, K.K., D.W. Bell, and R.N. Thorn. 2008. Floodplain hydrology after restoration of a southern Appalachian mountain stream. Wetlands 28:632-639.

National Oceanic and Atmospheric Administration, United States Department of Commerce (NOAA). 2011. Tidal Station Locations and Ranges. Oregon and Washington, Columbia River. http://co-ops.nos.noaa.gov/tides04/tab2wc1b.html. Site Accessed March 15, 2011. 
Nedland, Thomas S, Amy Wolf, and Tara Reed. 2007. A Reexamination of restored wetlands in Manitowoc County, Wisconsin. Wetlands, Vol 27, No 4, December 2007, pp. 999-1015.

Nielsen D and A Chick. 1997. Flood-mediated changes in aquatic macrophyte community structure. Marine Freshwater Research 48: 153-157.

Nygaard, Bettina and Rasmus Ejrnaes. 2009. The impacts of hydrology and nutrients on species composition and richness: evidence from a microcosm experiment. Wetlands Vol 29, No 1, pp. 187-195.

O’Neill, M. P. 1999. Distribution of native and non-native plant species in rural and urban riparian zones. Environmental Sciences and Resources. Portland State University. M. S. thesis. Portland, OR.

Office of Coast Survey (OCS). 2010. Historical Map and Chart Project. Available URL: http://historicalcharts.noaa.gov/historicals/historical_zoom.asp. Site Accessed 5/22/2010.

Ostrem, L. 1987. Studies on genetic variation in reed canary grass, Phalaris arundinacea. I. Alkaloid type and concentration. Hereditas 107: 235-248.

Partridge, James W. 2001. Persicaria amphibia (L.) Gray (Polygonum amphibium L.). Biological Flora of the British Isles. List Br. Vasc. Pl. (1958) no. 320, 8. Journal of Ecology 89, 487-501

Paveglio and Kilbride. 2000. Response of vegetation to control of reed canary grass in seasonally managed wetlands of southwestern Washington. Wildlife Society Bulletin. 28: $730-740$.

Perry L G and S M Galatowitsch. 2003. A test of two annual cover crops for controlling Phalaris arundinacea invasion in restored sedge meadow wetlands. Restoration Ecology 11: 297-307.

Pimentel, David, Lori Lach, Rodolfo Zuniga, and Doug Morrison. 2000. Environmental and economic costs of nonindigenous species in the United States. BioScience 50(1):5365 .

Rathcke, Beverly and Elizabeth P Lacey. 1985. Phenological patterns of terrestrial plants. Annual Review of Ecology and Systematics Vol 16 pp179-214.

Rice, J. S. and B. W. Pinkerton. 1993. Reed canary grass survival under cyclic inundation. Journal of Soil and Water Conservation 48:132-35. 
Sain, Riley E, William J Fonferek, Maurice S Simpson, K Wade Whittinghill. 1984. First-year vegetation following exposure of the Edmondson lake bed, Washington County, Virginia. Castanea Vol 49 No 4 pp. 158-166.

Schooler, Shon S, Peter B McEvoy, and Eric M Coombs. 2006. Negative per capita effects of purple loosestrife and reed canary grass on plant diversity of wetland communities. Diversity and Distributions, 12:351-363.

Shadel, William Paul and Jane Molofsky. 2002. Habitat and population effects on the germination and early survival of the invasive weed, Lythrum salicaria L. (purple loosestrife). Biological Invasions 4:413-423.

Shamsi, R A and F H Whitehead. 1974. Comparative eco-physiology of Epilobium hirsutum L. and Lythrum salicaria L.: I. general biology, distribution, and germination. Journal of Ecology Vol 62, no 1.

Sharp, M. M. 2002. Effect of physical soil properties on the distribution of native and non-native plants in urban riparian areas. Portland State University. M. S. thesis. Portland, OR.

Simmonds, N. W. 1945. Polygonum persicaria L. Journal of Ecology, Vol 33, No. 1 (Oct., 1945), pp. 121-131

Spyreas, Greg, Brian W Wilm, Allen E Plocher, David M Ketzner, Jeffrey W Matthews, James L Ellis, and Edward J Heske. 2010. Biological consequences of invasion by reed canarygrass (Phalaris arundinacea). Biological Invasions 12:1253-1267.

Stannard, M. and W. Crowder. 2001. Biology, history, and suppression of reed canarygrass (Phalaris arundinacea L.). U. S. Department of Agriculture, Natural Resources Conservation Service, Boise, ID, USA. TN Plant Materials No. 40.

Stewart, Elaine. 2010. Personal Communication. Metro Regional Government.

StreamNet GIS Data. 2010. Metadata for StreamNet Generalized Fish Distribution, All Species Combined. Portland, OR: StreamNet, July 2010. Site Accessed February 15, 2011. Available URL:

ftp://ftp.streamnet.org/pub/streamnet/gisdata/map_data_biological/StreamNet_FishDist_J uly2010.zip

Sultan S. E. and F. A. Bazzaz. 1993. Phenotypic plasticity in Polygonum persicaria. II. Norms of reaction to soil moisture and the maintenance of genetic diversity. Evolution, 47(4), 1993, pp. 1032-1049. 
Sutherland, William J. 1990. Iris pseudacorus L. British Ecological Society. Journal of Ecology, Vol 78, No 3 (Sep 1990) 833-848.

Tanner, C.D., J.R. Cordell, J. Rubey, and L. Tear. 2002. Restoration of freshwater intertidal habitat functions at Spencer Island, Everett, Washington. Restoration Ecology 10:564-576.

Theoharides, K.A., and J.S. Dukes. 2007. Plant invasion across space and time: factors affecting nonindigenous species success during four stages of invasion. New Phytologist 176: 256-273.

Timoney, K. 2002. A dying delta? A case study of a wetland paradigm. Wetlands 22:282-300.

Timoney, Kevin P. and George Argus. 2006. Willows, water regime, and recent cover change in the Peace-Athabasca Delta. Ecoscience 13(3): 308-317.

Timson, J. 1964. Germination in Polygonum. The University of Leicester, received 10 March 1964.

United States Army Corps of Engineers, Northwest Division (USACE). 2010. Columbia River at Vancouver Stage Height Records. Available URL: http://www.nwdwc.usace.army.mil/perl/dataquery.pl. Site Accessed 5/20/2010.

United States Environmental Protection Agency (USEPA). 2010. Wetlands Program Website. Available URL: http://www.epa.gov/OWOW/wetlands/vital/status.html. Site Accessed 5/12/2010.

United States Fish and Wildlife Service (USFWS). 1988. National list of vascular plant species that occur in wetlands. U.S. Fish \& Wildlife Service Biological Report 88 (26.9).

United States Fish and Wildlife Service (USFWS). 1993. 1993 supplement to list of plant species that occur in wetlands: Northwest (Region 9). Supplement to U.S. Fish \& Wildlife Service Biological Report 88 (26.9).

Van der Valk, A, L Squires, and C Welling. 1994. Assessing the impacts of an increase in water level on vegetation. Ecological Applications 4: 525-534.

Ward, J V, K Tockner, and F Schiemer. 1999. Biodiversity of floodplain river ecosystems: ecotones and connectivity. Regulated rivers: research and Management 15:125-139. 
Warren, R.S., P.E. Fell, R. Rozsa, A.H. Brawley, A.C. Orsted, E.T. Olson, V. Swamy, and W.A. Niering. 2002. Salt marsh restoration in Connecticut: 20 years of science and management. Restoration Ecology 10:497-513.

Water Science and Technology Board, Board on Environmental Studies and Toxicology (WSTB). 2004. Managing the Columbia River: Instream Flows, Water Withdrawals, and Salmon Survival. The National Academies Press, Washington, D.C.

Weiher, Evan, Irene C. Wisheu, Paul A. Keddy, and Dwayne R. J. Moore. 1996.

Establishment, persistence, and management implications of experimental wetland plant communities. Wetlands, Vol 16, No 2, June 1996, pp. 208-218.

Werner and Zedler. 2002. How sedge meadow soils, microtopography, and vegetation respond to sedimentation. Wetlands. 22: 451-466.

Wilson, Barbara L., Richard Brainerd, Danna Lytjen, Bruce Newhouse, and Nick Otting. 2008. Field Guide to the Sedges of the Pacific Northwest. Oregon State University Press, Corvallis, OR.

Youngman, J. L. 2002. Biogeographic and land cover effects on urban riparian plant assemblages. Environmental Sciences and Resources. Portland State University. M. S. thesis. Portland, OR.

Zar, J H. 1998. Biostatistical Analysis. 4th Edition, Prentice Hall, Englewood Cliffs, NJ, USA.

Zedler, J B and J C Callaway. 1999. Tracking wetland restoration: do mitigation sites follow desired trajectories? Restoration Ecology 7:69-73.

Zedler and Kercher. 2004. Causes and consequences of invasive plants in wetlands: opportunities, opportunists, and outcomes. Critical Reviews in Plant Sciences. 23: 431452. 


\section{Appendix A: List of Plant Species Found on Transects}

Table A-1: List of plant Species Found on Transects.

\begin{tabular}{|c|c|c|c|}
\hline Scientific Name & $\begin{array}{l}\text { Native/ } \\
\text { Invasive/ } \\
\text { Unknown }\end{array}$ & Scientific Name & $\begin{array}{l}\text { Native/ } \\
\text { Invasive/ } \\
\text { Unknown }\end{array}$ \\
\hline Alisma species & Unknown & Lysimachia nummularia & Invasive \\
\hline Alisma triviale & Native & Lythrum salicaria & Invasive \\
\hline Azolla mexicana & Native & Medicago lupulina & Invasive \\
\hline Betula species & Invasive & Mentha arvensis & Invasive \\
\hline Bidens cernua & Native & Mentha spicata & Invasive \\
\hline Bidens frondosa & Native & Moss & Unknown \\
\hline Cardamine species & Unknown & Myosotis laxa & Native \\
\hline Carex aperta & Native & Myriophyllum aquaticum & Invasive \\
\hline Carex species & Native & Phalaris arundinacea & Invasive \\
\hline Cirsium arvense & Invasive & Polygonum amphibium & Native \\
\hline Cirsium species & Invasive & Polygonum persicaria & Invasive \\
\hline Cirsium vulgare & Invasive & Polygonum species & Unknown \\
\hline Clematis vitalba & Invasive & Populus balsamifera & Native \\
\hline Cornus sericea & Native & Ranunculus sceleratus & Native \\
\hline Cyperus strigosus & Native & Ranunculus species & Unknown \\
\hline Deschampsia cespitosa & Native & Ribes lacustre & Native \\
\hline Dipsacus fullonum & Invasive & Rorippa curvisiliqua & Native \\
\hline Eleocharis acicularis & Native & Rubus armeniacus & Invasive \\
\hline Eleocharis ovata & Native & Rubus ursinus & Native \\
\hline Eleocharis palustris & Native & Rumex maritimus & Native \\
\hline Epilobium ciliatum & Native & Rumex species & Unknown \\
\hline Equisetum arvense & Unknown & Salix lucida lasiandra & Native \\
\hline Eragrostis hypnoides & Native & Salix sessifolia & Native \\
\hline Fabacea species & Unknown & Salix species & Native \\
\hline Fanleaf & Unknown & Sambucus racemosa & Native \\
\hline Fraxinus latifolia & Native & Schoenoplectus tabernaemontani & Native \\
\hline Galium aparine & Native & Solanum dulcamara & Invasive \\
\hline Galium trifidum & Native & Solanum nigrum & Invasive \\
\hline Gnaphalium palustre & Native & Spiraea douglasii & Native \\
\hline Gnaphalium species & Unknown & Taraxacum officinale & Invasive \\
\hline Gnaphalium uliginosum & Invasive & Typha latifolia & Native \\
\hline Holcus species & Invasive & Unknown Dicot Species & Unknown \\
\hline Hypericum perforatum & Invasive & Unknown Grass Species & Unknown \\
\hline Hypochaeris radicata & Invasive & Unknown Species & Unknown \\
\hline Iris pseudacorus & Invasive & Veronica americana & Native \\
\hline Juncus effusus & Unknown & Veronica species & Unknown \\
\hline Juncus species & Unknown & Vicia species & Unknown \\
\hline Leersia oryzoides & Native & & \\
\hline Lemna minor & Native & & \\
\hline Liverwort species & Unknown & & \\
\hline Lotus corniculatus & Invasive & & \\
\hline Ludwigia palustris & Native & & \\
\hline
\end{tabular}




\section{Appendix B: Differences in Results between Lakes}

Table B-1: Percent Cover Change and Significance, Bybee Lake.

\begin{tabular}{|c|c|c|c|c|c|c|}
\hline \multirow{2}{*}{$\begin{array}{l}\text { Bybee } \\
\text { Species } \\
\end{array}$} & \multicolumn{3}{|c|}{2003 to 2008} & \multicolumn{3}{|c|}{2003 to 2009} \\
\hline & 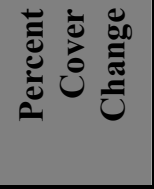 & 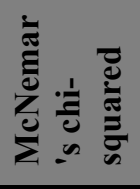 & p-value & 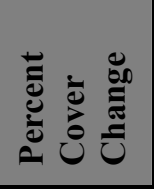 & 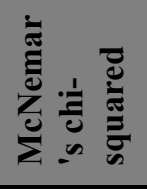 & p-value \\
\hline Phalaris & -16.62 & 998.71 & $<0.001$ & -13.34 & 668.66 & $<0.001$ \\
\hline Polygonum & 39.55 & 3364.56 & $<0.001$ & 43.02 & 3814.70 & $<0.001$ \\
\hline Salix & 5.16 & 321.42 & $<0.001$ & 5.41 & 339.15 & $<0.001$ \\
\hline Bidens & 4.70 & 206.27 & $<0.001$ & 2.64 & 80.23 & $<0.001$ \\
\hline Carex & 1.62 & 126.82 & $<0.001$ & 2.09 & 172.70 & $<0.001$ \\
\hline Cirsium species & -0.33 & 16.28 & $<0.001$ & -0.45 & 28.00 & $<0.001$ \\
\hline Cornus sericea & 0.00 & NA & Not Sig & 0.00 & NA & Not Sig \\
\hline Cyperus strigosus & -5.54 & 428.24 & $<0.001$ & -4.13 & 200.06 & $<0.001$ \\
\hline Eleocharis palustris & 0.12 & 0.52 & Not Sig & 1.72 & 80.75 & $<0.001$ \\
\hline Eleocharis species & -0.57 & 5.71 & $<0.05$ & -0.79 & 10.78 & $<0.05$ \\
\hline Epilobium ciliatum & -0.55 & 51.02 & $<0.001$ & -0.41 & 23.05 & $<0.001$ \\
\hline Eragrostis hypnoides & 0.00 & NA & Not Sig & 4.59 & 437.00 & $<0.001$ \\
\hline Fraxinus latifolia & 1.80 & 170.01 & $<0.001$ & 1.79 & 169.01 & $<0.001$ \\
\hline Gnaphalium species & 5.69 & 405.56 & $<0.001$ & 8.81 & 692.44 & $<0.001$ \\
\hline Iris pseudacorus & 0.20 & 17.05 & $<0.001$ & 0.28 & 25.04 & $<0.001$ \\
\hline Juncus species & -0.58 & 53.02 & $<0.001$ & -0.58 & 53.02 & $<0.001$ \\
\hline Ludwigia & 0.53 & 0.72 & Not Sig & 2.58 & 19.10 & $<0.001$ \\
\hline Lythrum salicaria & 0.03 & 0.31 & Not Sig & 0.40 & 28.52 & $<0.001$ \\
\hline M. aquaticum (Smith Only) & & - & Not Sig & NA & - & Not Sig \\
\hline Populus balsamifera & -0.87 & 77.29 & $<0.001$ & -0.80 & 59.84 & $<0.001$ \\
\hline Ranunculus species & -0.02 & 0.50 & Not Sig & -0.02 & 0.50 & Not Sig \\
\hline Rorippa curvisiliqua & 1.63 & 53.69 & $<0.001$ & 2.52 & 109.99 & $<0.001$ \\
\hline Rubus armeniacus & -0.02 & 0.50 & Not Sig & -0.02 & 0.50 & Not Sig \\
\hline Rumex species & -2.42 & 227.04 & $<0.001$ & -0.39 & 31.38 & $<0.001$ \\
\hline Rubus ursinus & -0.27 & 18.38 & $<0.001$ & -0.24 & 13.08 & $<0.001$ \\
\hline S. tabernaemontani & 0.00 & NA & Not Sig & 0.00 & NA & Not Sig \\
\hline Solanum species & -1.45 & 103.70 & $<0.001$ & -1.37 & 84.92 & $<0.001$ \\
\hline Unknown & 12.15 & 512.98 & $<0.001$ & -3.32 & 82.56 & $<0.001$ \\
\hline Veronica & -1.00 & 9.73 & $<0.05$ & 7.10 & 336.75 & $<0.001$ \\
\hline
\end{tabular}


Table B2: Percent Cover Change and Significance, Smith Lake.

\begin{tabular}{|c|c|c|c|c|c|c|}
\hline \multirow{2}{*}{$\begin{array}{l}\text { Smith } \\
\\
\text { Species }\end{array}$} & \multicolumn{3}{|c|}{2003 to 2008} & \multicolumn{3}{|c|}{2003 to 2009} \\
\hline & 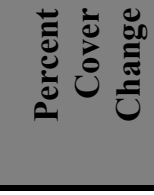 & 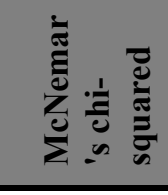 & p-value & 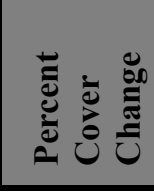 & 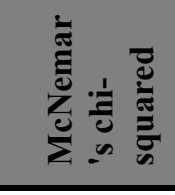 & p-value \\
\hline Phalaris & -17.07 & 1752.25 & $<0.001$ & -18.20 & 1992.01 & $<0.001$ \\
\hline Polygonum & 29.76 & 3194.72 & $<0.001$ & 25.82 & 2471.20 & $<0.001$ \\
\hline Salix & 9.31 & 612.36 & $<0.001$ & 4.09 & 123.97 & $<0.001$ \\
\hline Bidens & -10.84 & 841.60 & $<0.001$ & -11.91 & 1062.83 & $<0.001$ \\
\hline Carex & 2.57 & 316.20 & $<0.001$ & 1.97 & 235.72 & $<0.001$ \\
\hline Cirsium species & -1.25 & 159.03 & $<0.001$ & -1.33 & 185.25 & $<0.001$ \\
\hline Cornus sericea & 0.49 & 70.01 & $<0.001$ & 0.50 & 71.01 & $<0.001$ \\
\hline Cyperus strigosus & -4.89 & 599.93 & $<0.001$ & -4.47 & 480.50 & $<0.001$ \\
\hline Eleocharis palustris & -1.69 & 133.00 & $<0.001$ & -2.07 & 229.95 & $<0.001$ \\
\hline Eleocharis species & -2.59 & 210.87 & $<0.001$ & -1.21 & 35.69 & $<0.001$ \\
\hline Epilobium ciliatum & -1.01 & 141.17 & $<0.001$ & -0.97 & 129.10 & $<0.001$ \\
\hline Eragrostis hypnoides & 0.01 & 0.50 & Not Sig & 0.46 & 65.01 & $<0.001$ \\
\hline Fraxinus latifolia & 0.79 & 103.97 & $<0.001$ & 1.28 & 178.26 & $<0.001$ \\
\hline Gnaphalium species & -0.04 & 0.09 & Not Sig & -0.28 & 20.93 & $<0.001$ \\
\hline Iris pseudacorus & 0.16 & 22.04 & $<0.001$ & 0.32 & 45.02 & $<0.001$ \\
\hline Juncus species & -0.01 & 91.09 & $<0.001$ & -0.01 & 94.01 & $<0.001$ \\
\hline Ludwigia & -10.71 & 596.03 & $<0.001$ & -5.19 & 142.65 & $<0.001$ \\
\hline Lythrum salicaria & 0.09 & 4.97 & $<0.05$ & 0.12 & 7.76 & $<0.05$ \\
\hline M. aquaticum (Smith Only) & 0.06 & 719.65 & $<0.001$ & 0.05 & 565.47 & $<0.001$ \\
\hline Populus balsamifera & 0.68 & 42.25 & $<0.001$ & 0.59 & 30.69 & $<0.001$ \\
\hline Ranunculus species & -2.00 & 289.00 & $<0.001$ & -2.00 & 286.03 & $<0.001$ \\
\hline Rorippa curvisiliqua & -0.59 & 16.55 & $<0.001$ & -1.39 & 123.27 & $<0.001$ \\
\hline Rubus armeniacus & -0.97 & 124.84 & $<0.001$ & -1.00 & 138.32 & $<0.001$ \\
\hline Rumex species & -1.98 & 215.63 & $<0.001$ & -2.18 & 281.28 & $<0.001$ \\
\hline Rubus ursinus & 0.02 & 0.17 & Not Sig & -0.01 & 0.00 & Not Sig \\
\hline S. tabernaemontani & -0.05 & 5.14 & $<0.05$ & -0.02 & 0.10 & Not Sig \\
\hline Solanum species & -0.43 & 15.19 & $<0.001$ & -0.71 & 46.94 & $<0.001$ \\
\hline Unknown & 23.77 & 2775.42 & $<0.001$ & 0.47 & 3.50 & Not Sig \\
\hline Veronica & -0.29 & 38.77 & $<0.001$ & -0.73 & 4.58 & $<0.05$ \\
\hline
\end{tabular}


Table B-3: Elevation-Based Cover Change Significance, By Lake.

\begin{tabular}{|c|c|c|c|c|c|c|c|c|}
\hline \multirow[b]{2}{*}{ Species } & \multirow[b]{2}{*}{ Lake } & \multirow[b]{2}{*}{$\begin{array}{l}\text { Elevation } \\
\text { Split }\end{array}$} & \multirow{2}{*}{$\begin{array}{l}2008 \\
\chi^{2} \\
\end{array}$} & \multirow{2}{*}{$\begin{array}{l}2008 \\
\text { p-value }\end{array}$} & \multirow{2}{*}{$\begin{array}{l}2009 \\
\chi^{2} \\
\end{array}$} & \multirow{2}{*}{$\begin{array}{l}2009 \\
\text { p-value }\end{array}$} & 2008 & 2009 \\
\hline & & & & & & & \multicolumn{2}{|c|}{$\begin{array}{l}\text { Direction of } \\
\text { Change }\end{array}$} \\
\hline Phalaris & Smith & above 2.7 & 1.59 & Not Sig & 11.70 & $<0.001$ & $\downarrow$ & $\downarrow$ \\
\hline Phalaris & Smith & below 2.7 & 1930.34 & $<0.001$ & 2148.33 & $<0.001$ & $\downarrow$ & $\downarrow$ \\
\hline Phalaris & Bybee & above 2.4 & 0.06 & Not Sig & 8.81 & $<0.05$ & $\uparrow$ & $\uparrow$ \\
\hline Phalaris & Bybee & below 2.4 & 1502.78 & $<0.001$ & 1197.45 & $<0.001$ & $\downarrow$ & $\downarrow$ \\
\hline Salix & Smith & above 2.1 & 1609.10 & $<0.001$ & 1005.42 & $<0.001$ & $\uparrow$ & $\uparrow$ \\
\hline Salix & Smith & below 2.1 & 214.21 & $<0.001$ & 750.55 & $<0.001$ & $\downarrow$ & $\downarrow$ \\
\hline Salix & Bybee & above 2.1 & 312.72 & $<0.001$ & 306.16 & $<0.001$ & $\uparrow$ & $\uparrow$ \\
\hline Salix & Bybee & below 2.1 & 34.83 & $<0.001$ & 50.18 & $<0.001$ & $\uparrow$ & $\uparrow$ \\
\hline Bidens & Smith & above 2.5 & 201.582 & $<0.001$ & 108.02 & $<0.001$ & $\uparrow$ & $\uparrow$ \\
\hline Bidens & Smith & below 2.5 & 1445.66 & $<0.001$ & 1600.89 & $<0.001$ & $\downarrow$ & $\downarrow$ \\
\hline Bidens & Bybee & above 2.2 & 473.20 & $<0.001$ & 237.19 & $<0.001$ & $\uparrow$ & $\uparrow$ \\
\hline Bidens & Bybee & below 2.2 & 46.25 & $<0.001$ & 11.80 & $<0.001$ & $\downarrow$ & $\downarrow$ \\
\hline Ludwigia & Smith & above 2.4 & 23.77 & $<0.001$ & 125.61 & $<0.001$ & $\uparrow$ & $\uparrow$ \\
\hline Ludwigia & Smith & below 2.4 & 1358.70 & $<0.001$ & 721.54 & $<0.001$ & $\downarrow$ & $\downarrow$ \\
\hline Ludwigia & Bybee & above 2.1 & 10.59 & $<0.05$ & 0.16 & Not Sig & $\downarrow$ & $\uparrow$ \\
\hline Ludwigia & Bybee & below 2.1 & 30.38 & $<0.001$ & 44.10 & $<0.001$ & $\uparrow$ & $\uparrow$ \\
\hline
\end{tabular}




\section{Appendix C: Elevation Survey Details}

Table C-1: Bench Mark Summary.

Location, elevation, and source of Bench Marks used in the 2010 and 2004 elevation surveys. Elevations are presented in original datum elevation and NGVD 1929 (the datum used for this project).

\begin{tabular}{|c|c|c|c|c|c|c|}
\hline $\begin{array}{l}\text { Bench } \\
\text { Mark } \\
\text { \# on } \\
\text { Map }\end{array}$ & Datum & Elevation & $\begin{array}{l}\text { Elevation } \\
\text { NGBD } 29\end{array}$ & Transects & Location & $\begin{array}{l}\text { Source and Other } \\
\text { Information }\end{array}$ \\
\hline \multicolumn{7}{|c|}{$\begin{array}{l}\text { Bench Marks used for } 2010 \text { Elevation Survey. I used the closest and/or most accurate Bench } \\
\text { Marks available. }\end{array}$} \\
\hline 1 & COP & 30.861 & 29.486 & $\mathrm{~A}, \mathrm{~B}$ & $\begin{array}{l}\text { East side of N. } \\
\text { Portland Rd; in base } \\
\text { of bike path bollard; } \\
200^{\prime}+/ \text { - sly of RR } \\
\text { overpass }\end{array}$ & $\begin{array}{l}\text { City of Portland. COP } \\
\text { BM \# 4265. 2N 1E } \\
\text { 32D }\end{array}$ \\
\hline 2 & $\mathrm{COP}$ & 37.1 & 35.725 & $\begin{array}{l}\text { C, D, E, } \\
F, G\end{array}$ & $\begin{array}{l}\text { East side of N. } \\
\text { Portland Rd; in base } \\
\text { of bike path bollard; } \\
200^{\prime}+/- \text { nly of } \\
\text { Columbia Slough }\end{array}$ & $\begin{array}{l}\text { City of Portland. COP } \\
\text { BM \# 4280. 1N 1E } \\
05 B\end{array}$ \\
\hline 3 & $\begin{array}{l}\text { NAVD } \\
88\end{array}$ & 18.4 & 15.18 & $\begin{array}{l}\mathrm{G}, \mathrm{H}, \mathrm{I}, \mathrm{J} \\
\mathrm{K}\end{array}$ & $\begin{array}{l}\text { South side of Smith } \\
\text { Lake. Found by } \\
\text { following "bird } \\
\text { count trail" marked } \\
\text { with blue flags that } \\
\text { starts at the SE } \\
\text { corner of the landfill } \\
\text { by the stormwater } \\
\text { pond. }\end{array}$ & $\begin{array}{l}\text { Multnomah County } \\
\text { Surveyor's Office. } \\
\text { BM \# 3072. Marker is } \\
\text { a round brass disk set } \\
\text { in concrete with } \\
\text { T2NR1W and } \\
\text { T2NR1E, M.C. and } 36 \\
\text { \& } 31 \text { marked on it. } \\
\text { May wish to use a } \\
\text { more permanent } \\
\text { Bench Mark in the } \\
\text { future }\end{array}$ \\
\hline 4 & $\begin{array}{l}\text { NGVD } \\
29\end{array}$ & 13 & 13 & $\mathrm{~L}, \mathrm{~N}, \mathrm{O}$ & $\begin{array}{l}\text { Cement of Water } \\
\text { Control Structure } \\
\text { near staff gauge in } \\
\text { North Slough }\end{array}$ & $\begin{array}{l}\text { Metro Regional } \\
\text { Government. This } \\
\text { Bench Mark and the } \\
\text { staff gauges are off by } \\
1.9 \text { feet from NGVD } \\
29 \text {. This correction is } \\
\text { already accounted for } \\
\text { in the 'Elevation' } \\
\text { columns. }\end{array}$ \\
\hline 5 & $\mathrm{COP}$ & 29.331 & 27.956 & $\begin{array}{l}\mathrm{P}, \mathrm{Q}, \mathrm{R} \\
\mathrm{S}, \mathrm{T}\end{array}$ & $\begin{array}{l}\text { South side of N. } \\
\text { Marine Dr; Ilum. } \\
\text { Pole base; } 100 \mathrm{ft} \\
\text { West of East } \\
\text { driveway } 6102 \mathrm{~N} . \\
\text { Marine Dr. }\end{array}$ & $\begin{array}{l}\text { City of Portland. COP } \\
\text { BM \# 3338. 2N 1E } \\
30 \mathrm{C} \text {. }\end{array}$ \\
\hline
\end{tabular}




\begin{tabular}{|c|c|c|c|c|c|c|}
\hline $\begin{array}{l}\text { Bench } \\
\text { Mark } \\
\text { \# on } \\
\text { Map } \\
\end{array}$ & Datum & Elevation & $\begin{array}{l}\text { Elevation } \\
\text { NGBD } 29\end{array}$ & Transects & Location & $\begin{array}{l}\text { Source and Other } \\
\text { Information }\end{array}$ \\
\hline 6 & $\mathrm{COP}$ & 28.823 & 27.448 & $\begin{array}{l}\text { M, U, V, } \\
\text { W, X, Y, } \\
\text { Z }\end{array}$ & $\begin{array}{l}\text { South side of N. } \\
\text { Marine Dr; Ilum. } \\
\text { Pole base; } 120 \mathrm{ft} \\
\text { East of WPL } 5357 \\
\text { N. Marine Dr. }\end{array}$ & $\begin{array}{l}\text { City of Portland. COP } \\
\text { BM \# 3375. 2N 1E } \\
31 \mathrm{~A} .\end{array}$ \\
\hline \multicolumn{7}{|c|}{ Additional Bench Marks used in the 2004 Elevation Survey } \\
\hline 7 & $\mathrm{COP}$ & 13 & 11.625 & A, B & $\begin{array}{l}\text { Smith Lake Canoe } \\
\text { Launch. This Bench } \\
\text { Mark could not be } \\
\text { located during the } \\
2010 \text { survey. }\end{array}$ & $\begin{array}{l}\text { G \& L Surveyors, } \\
\text { Metro subcontractor. } \\
\text { Based on phone } \\
\text { conversations with } \\
\text { Metro and the COP, it } \\
\text { appears this Bench } \\
\text { Mark was abandoned. }\end{array}$ \\
\hline 8 & COP & 44.624 & 43.249 & $\mathrm{C}, \mathrm{D}, \mathrm{E}, \mathrm{F}$ & $\begin{array}{l}\text { N. Portland Rd } \\
\text { Bridge }\end{array}$ & $\begin{array}{l}\text { Metro Regional } \\
\text { Government }\end{array}$ \\
\hline 9 & COP & 17.45 & 16.075 & Unknown & $\begin{array}{l}\text { Well \# P-4 (ground } \\
\text { elevation). This } \\
\text { Bench Mark could } \\
\text { not be located in the } \\
2010 \text { survey. }\end{array}$ & $\begin{array}{l}\text { Metro Regional } \\
\text { Government }\end{array}$ \\
\hline 10 & $\begin{array}{l}\text { NAVD } \\
88\end{array}$ & 15.5 & 12.025 & Unknown & $\begin{array}{l}\text { East side of landfill. } \\
\text { Located downslope } \\
\text { and in the wetland } \\
\text { area on the west end } \\
\text { of Smith Lake. It } \\
\text { was noted to appear } \\
\text { near piezometer P-9. } \\
\text { North of Bench } \\
\text { Mark } 11 \text { (pt \# 3079). }\end{array}$ & $\begin{array}{l}\text { Multnomah County } \\
\text { Surveyor's Office. } \\
\text { Point \# } 3076 .\end{array}$ \\
\hline 11 & $\begin{array}{l}\text { NAVD } \\
88\end{array}$ & 14.4 & 10.925 & Unknown & $\begin{array}{l}\text { East side of landfill. } \\
\text { Located downslope } \\
\text { and in the wetland } \\
\text { area on the west end } \\
\text { of Smith Lake. Near } \\
\text { piezometer P-9, } \\
\text { south of Bench } \\
\text { Mark } 10(\mathrm{pt} \# 3076)\end{array}$ & $\begin{array}{l}\text { Multnomah County } \\
\text { Surveyor's Office. } \\
\text { Point \# } 3079 .\end{array}$ \\
\hline 12 & COP & 13.02 & 11.645 & Unknown & $\begin{array}{l}\text { Piezometer P-8 } \\
\text { (ground elevation). } \\
\text { This Bench Mark } \\
\text { could not be located } \\
\text { in the } 2010 \text { survey. }\end{array}$ & $\begin{array}{l}\text { Metro Regional } \\
\text { Government }\end{array}$ \\
\hline
\end{tabular}




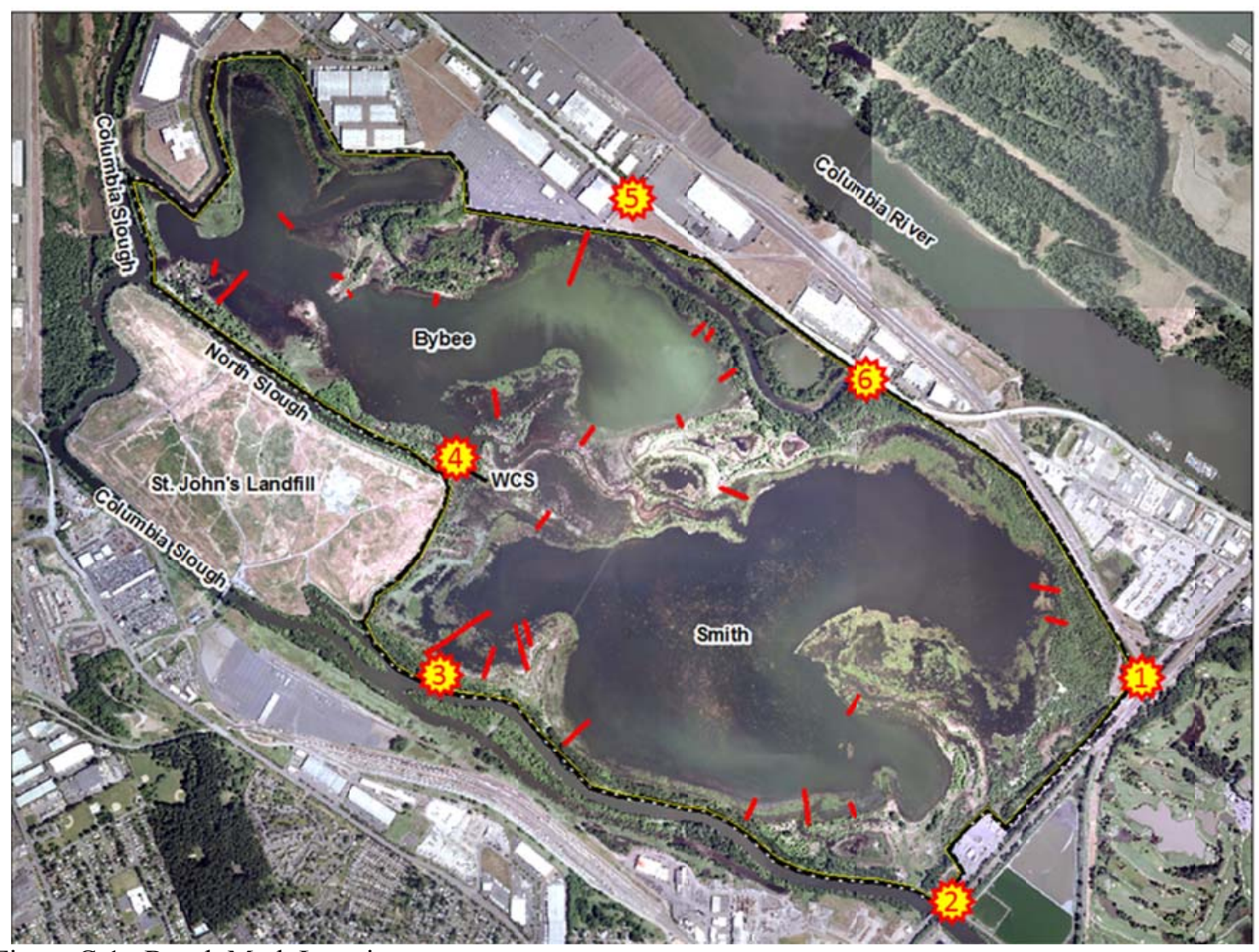

Figure C-1: Bench Mark Locations:

The locations of Bench Marks used for the 2010 elevation survey, transects, and other major features are included on this map. Bench Marks for the 2004 elevation survey are not included unless they were also used in the 2010 survey as several of the 2004 Bench Marks could not be located in 2010 . 